2018

\title{
Advances in switchable and highly insulating autonomous (self- powered) glazing systems for adaptive low energy buildings
}

Aritra Ghosh

University of Exeter, a.ghosh@exeter.ac.uk

Brian Norton

Technological University Dublin, brian.norton@tudublin.ie

Follow this and additional works at: https://arrow.tudublin.ie/dubenart

Part of the Environmental Sciences Commons

\section{Recommended Citation}

Aritra Ghosh, Brian Norton, Advances in switchable and highly insulating autonomous (self-powered) glazing systems for adaptive low energy buildings, Renewable Energy, Volume 126, 2018, Pages 1003-1031, ISSN 0960-1481, DOI: 10.1016/j.renene.2018.04.038.

This Article is brought to you for free and open access by the Dublin Energy Lab at ARROW@TU Dublin. It has been accepted for inclusion in Articles by an authorized administrator of ARROW@TU Dublin. For more information, please contact arrow.admin@tudublin.ie, aisling.coyne@tudublin.ie,gerard.connolly@tudublin.ie. Funder: Higher Education Authority, Ireland 
Review

\title{
Advances in switchable and highly insulating autonomous (self- powered) glazing systems for adaptive low energy buildings
}

\author{
Aritra Ghosh ${ }^{\mathrm{a}, \mathrm{b}, *}$, Brian Norton ${ }^{\mathrm{a}}$ \\ a Dublin Energy Lab, Dublin Institute Technology, Grangegorman, Dublin 7, Ireland \\ ${ }^{\mathrm{b}}$ Environmental and Sustainability Institute, University of Exeter, Penryn, Cornwall, TR10 9DF, UK
}

\section{A R T I C L E I N F O}

\section{Article history:}

Received 24 January 2018

Received in revised form

8 April 2018

Accepted 9 April 2018

Available online 12 April 2018

\section{Keywords:}

Glazing

Electrochromic (EC)

Suspended particle device (SPD)

Liquid crystal (LC)

Phase change material (PCM)

Aerogel

Vacuum

PV

Chromic

\begin{abstract}
A B S T R A C T
Building energy reduction requires highly advanced low heat loss, heat gain and comfortable daylight allowing glazing. Presently available glazing systems are classified mainly in two categories, controlling solar heat gain and controlling low heat loss. Low heat loss through glazing systems can be achieved by (i) suppression of convection in the air between the outer panes by use of multiple glass panes or aerogels, (ii) having an inert gas or vacuum between the panes to reduce or eliminate respectively convective heat transfer. In all these systems, low emissivity coatings are also required to reduce the radiative heat transfer. Low heat glazing allows large areas of a building façade to be glazed without large attendant heat losses. However, they require the addition of an ability to switch from transparent to opaque to avoid excessive solar heat gain and to control glare. Electrically actuated electrochromic, liquid crystal and suspended particle device glazing systems and non-electrically-actuated thermochromic, thermotropic, and gasochromic glazing systems offer control of solar heat gain control and daylight. Recent relevant developments are reviewed with the contemporary status of each technology provided.
\end{abstract} () 2018 Elsevier Ltd. All rights reserved.

\section{Contents}

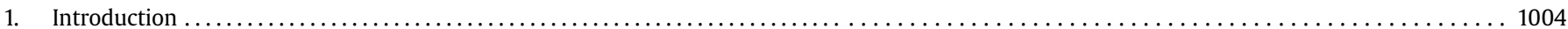

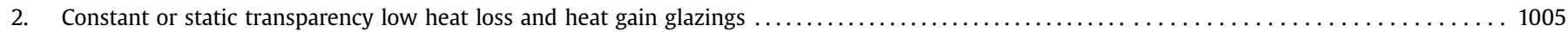

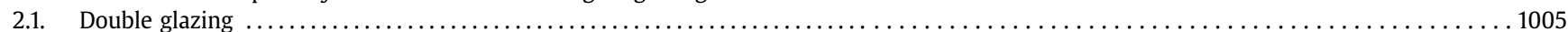

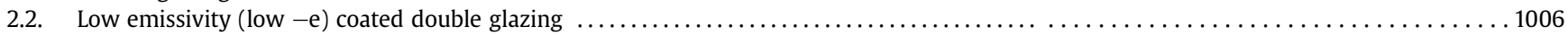

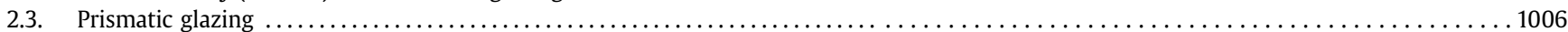

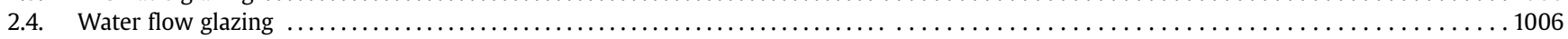

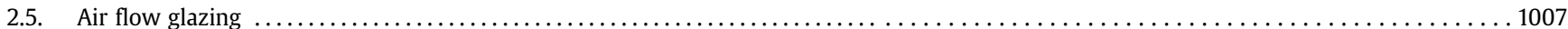

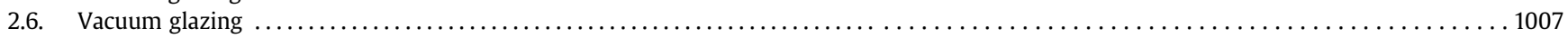

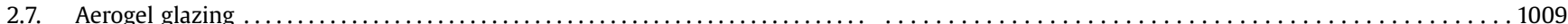

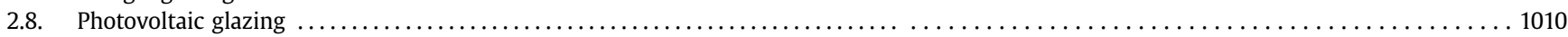

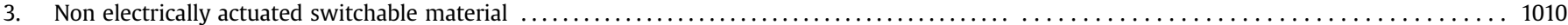

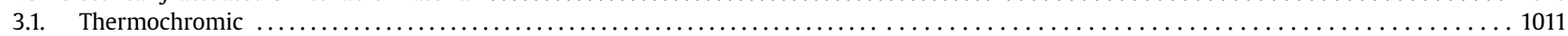

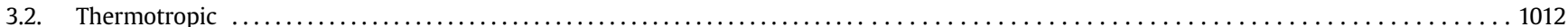

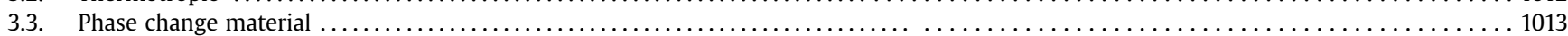

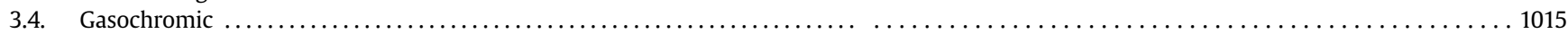

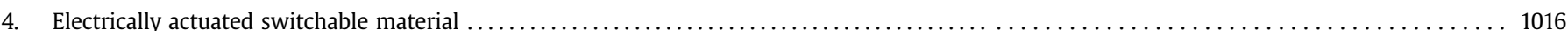

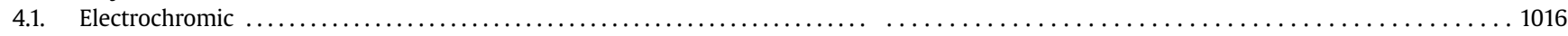

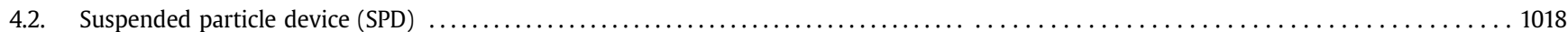

\footnotetext{
* Corresponding author. Dublin Energy Lab, Dublin Institute Technology, Grangegorman, Dublin 7, Ireland.

E-mail addresses: a.ghosh@exeter.ac.uk, aritraghosh_9@yahoo.co.in (A. Ghosh).
} 


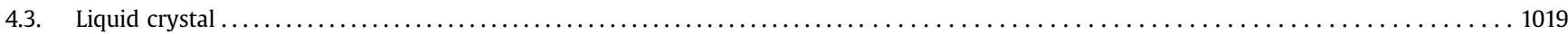

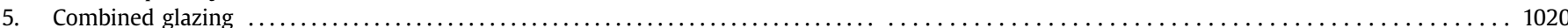

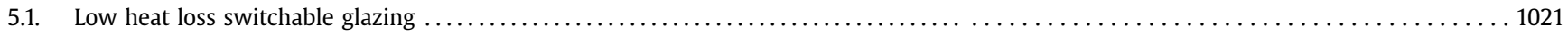

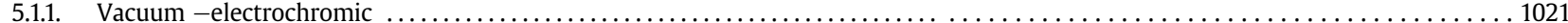

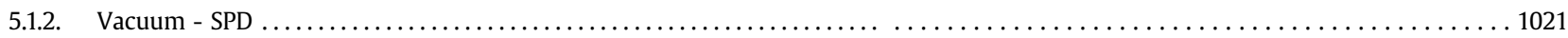

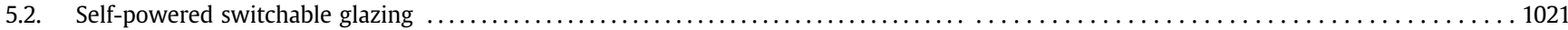

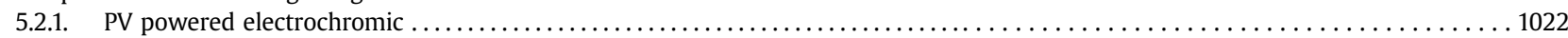

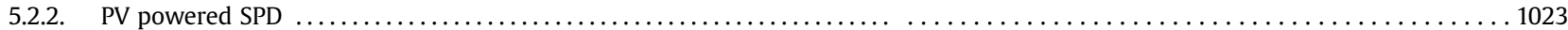

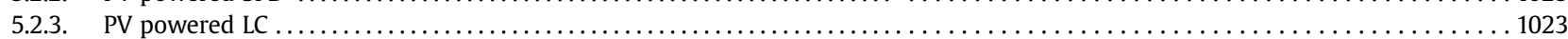

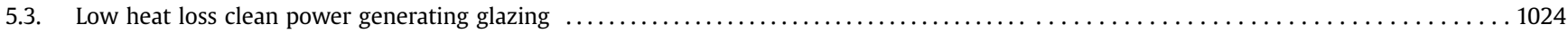

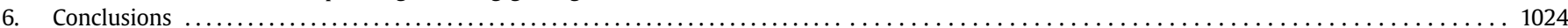

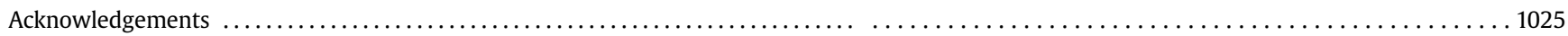

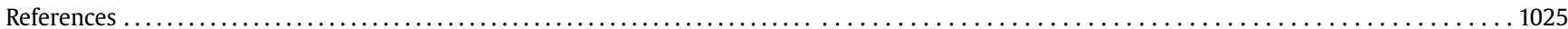

\section{Introduction}

Glazing visually connects interior spaces with the outdoor environment to offer daylight, conducive to good health and working or living conditions. However, a large glazed area can incur (i) high heat losses increasing a building heating load in cold conditions, and (ii) a large cooling load to remove solar gains in hot conditions. These attributes combined with the energy used to more generally ensure comfort conditions and artificial lighting head to buildings thus consuming $40 \%$ of global energy to meet heating, cooling and lighting energy demands, though this varies in different countries. For example $41 \%$ of energy in US and the EU but $25 \%$ in China [1]. In Japan, the building sector consumes $14.2 \%$ energy, which has doubled compared to 1970s [2]. Buildings generate one-third of global greenhouse gas emissions (GHG) being responsible for $32 \%$ of GHG emissions in Europe, $48 \%$ in USA and 33\% in Australia [3-5]. In Australia commercial building emissions are projected to increase GHG emissions by $154 \%$ from 2005 to 2050 [3,4]. It was reported in 2003 that the $\mathrm{CO}_{2}$ emissions in the residential sector of Japan of 50.5 million tonnes of carbon had increased by 43.5\% in comparison with 1990 [6] [7]. Space heating, cooling and lighting are the main uses of energy in residential and commercial buildings. Building energy performance improvement is an important part of European Union (EU) 2020 and 2030 energy targets (EU Commission, 2011)[8] to meet EU Kyoto Protocol commitments for $\mathrm{CO}_{2}$ emissions reduction [9]. In developing new Net Zero Energy Buildings (NZEB), renewable sources [10,11] placed near to the point of use [12] to reduce power transmission losses. In NZEB, glazing systems can play a vital role in ensuring low cooling, heating, and lighting loads $[13,14]$. The existing building stock lower energy consumption can be achieved by retrofitting windows as part of an overall refurbishment that may also include heating system upgrade, heat recovery, and thermal insulation [15-17]. Glazings are responsible for $20-40 \%$ of energy used in a building [18-20]. Insulation and retrofitting lower heat loss glazing can together reduce annual energy of a building by $47 \%$ [21].

Buildings glazing enhance cooling load demand due to excessive entering solar heat gain, heat loss from inside to outside via a glazing, which incurs a heating load demand and lack of daylight gives rise to an electric lighting energy demand and excess artificial lighting energy, can create glare issues. Fig. 1 shows a detail working principle of a window.

Solar heat gain coefficient (SHGC) is the fraction of incident solar radiation enters a room through a glazing in the form of transmitted radiation or as secondary heat gains due to the inward flowing fraction of thermal radiation from the window [22]. High SHGC of glazing increases the cooling load of building in summer and in hot climates, whereas a high SHGC is beneficial for winter

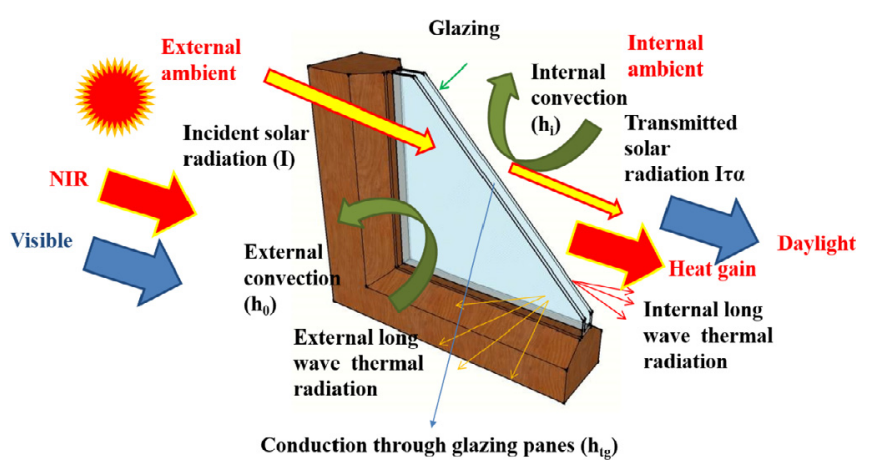

Fig. 1. Heat loss, heat gain and daylighting from a window.

and cold climates [23].

Overall heat loss coefficient ( $U$-value) of a glazing depends on internal $\left(h_{i}\right)$ and external $\left(h_{0}\right)$ heat transfer coefficient and thermal conductance of a glazing as shown in Fig. 1.

Daylight in those wavelengths is sunlight that matches human spectral visual response [24-28]. Daylight through a window can provide an attractive visually pleasing environment. Daylight illuminances at a point in a building depend on (i) the total daylight from the sky (given, for example, by the horizontal external illuminance) (ii) the angular distribution of light over the sky vault, given by the sky luminance distribution [27] (iii) the size and locations of windows, size of reflectance and locations of internal surfaces. Use of daylight can reduce 50-80\% lighting energy consumption while primary energy (heating + cooling + lighting)

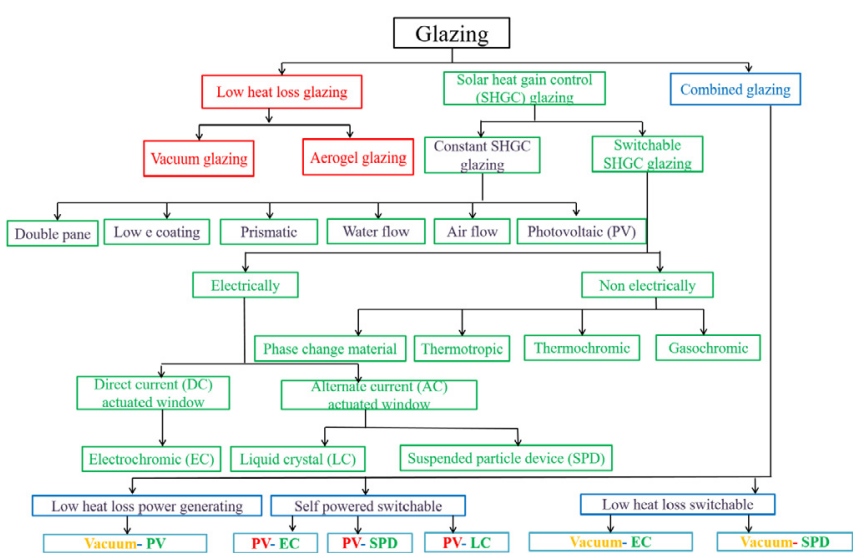

Fig. 2. Taxonomy of available switchable and non-switchable glazing. 
savings from daylight displacing artificial electric lighting can reach $40 \%$ [29]. For example, for cooling-dominated office buildings in Hong Kong, the peak cooling load and the annual electricity consumption were reduced by $11 \%$ and by $13 \%$, respectively by use of daylighting [30]. Energy saving of $10 \%$ can be achieved by using daylighting strategies in Malaysian buildings [31]. Shading devices are used traditionally to control excessive heat gain and glare. Switchable (or so called smart, adaptive, responsive, dynamic, intelligent) glazings which modulate their thermo-optical properties in response to external stimuli, can also be used to modulate the entering solar spectrum [32].

Fig. 2 classify the different advanced switchable and nonswitchable glazing based on their functionality. For adaptive or responsive building, constant or static transparency glazings are not suitable. Adaptation from second to seasonal, switchable glazings are attractive [33]. Recently review works on development and status of glazings have been performed by Refs. [34-38]. Jelle et al. gave an ample information about industry details of glazing which is interesting [34] as product details from industries are difficult to achieve. According to Baeteans et al. [37], electrochrmoic (EC) is preferable due to its higher visible spectrum compared to liquid crystal (LC) and suspended particle device (SPD) glazing. Glazing work between 1990 and 2000 was summarised by Seeboth et al. [38] which included electrochromic devices, thermotropic gels and polymer dispersed liquid crystalline systems. Gorgolis and Karamanis [36] discussed extensively about electrochromic, thermochromic, photovoltaic and other advanced glazings. Investigation on LC and SPD was excluded in that work. Rezaei et al. [35] concluded that an ideal glazing should possess self-powered, spectrally tunable and high visibly transmission properties. However, this review excluded combined glazings, LC and SPD glazing systems.

Further investigation on progress of material development and system integration had been performed after those aforementioned review works. This work covers present status of advanced glazing primarily performed by different research group and commercial availability of those glazing. Higher attention was given to switchable/smart/dynamic/adaptive glazing application particularly electrically activated switchable EC, SPD and LC type and their combined system works for low energy adaptive building application. The focus is on low $U$-values and solar heat gain coefficient (SHGC), daylight control. Mechanically operated blinds, shades, glazing frames, self-cleaning glazing are not part of this study.

First section of this paper will discuss about the constant transparency glazing, which includes both solar heat gain controlled double, low emissivity coating, prismatic, and photovoltaic type and low heat loss vacuum and aerogel. Detailed performance and recent developments of electrically and nonelectrically actuated switchable glazing systems are discussed. At the end for the first time, recent development of combined glazing systems and their status have been thoroughly investigated.

\section{Constant or static transparency low heat loss and heat gain glazings}

This section aims to outline the research currently being undertaken to improve glazing technologies and product. First six glazing technologies such as solar control double glazing, low emissivity coated glazing, prismatic, water flow, air flow are mainly used to control solar factor or solar heat gain. Vacuum glazing and aerogel glazing contribute to control of low heat loss. Photovoltaic glazing has triple point advantages as it can control solar gain, admit comfortable daylight and generate clean electricity at the demand site. Thus, this section includes heat loss, heat gain control glazing which has single (constant/static) transparency.

\subsection{Double glazing}

The heat loss through double-glazing depends on the gap between two glass panes [39]. A photograph of double glazing is shown in Fig. 3. For ambient temperature ranging $19-49^{\circ} \mathrm{C}$, the optimal gap (optimal air layer thickness) was found to be in the range of $12-21 \mathrm{~mm}[40,41]$ to save energy losses through air-fitted double glazing in Turkey. Fig. 4 shows the variation of investment, heating and total cost with air layer thickness for Iskenderun city in Turkey. In the figure when insulation thickness increases, heating cost decreases. After a critical layer thickness, convective heat transfer dominates which increase the heating cost [39].

Air has a thermal conductivity of $0.026 \mathrm{~W} / \mathrm{mK}$ compared with the lower thermal conductivity of the alternative gases such as Argon at $0.018 \mathrm{~W} / \mathrm{mK}$, Krypton at $0.0095 \mathrm{~W} / \mathrm{mK}$ and Xenon at $0.0055 \mathrm{~W} / \mathrm{mK}$. Argon filled glazing has a low cost than use of Krypton or Xenon [34]. Infra-red absorbing gases composed of either difluoromethane (HFC-32), norflurane (HFC-134a), trifluoroethane (HFC-143a) and sulfur hexafluoride (SF6) in equal parts or dichlorodifluoromethane (CFC-12), CFC-13, CFC-14 and SF6 in equal parts [42-44] can be used to reduce the direct radiative

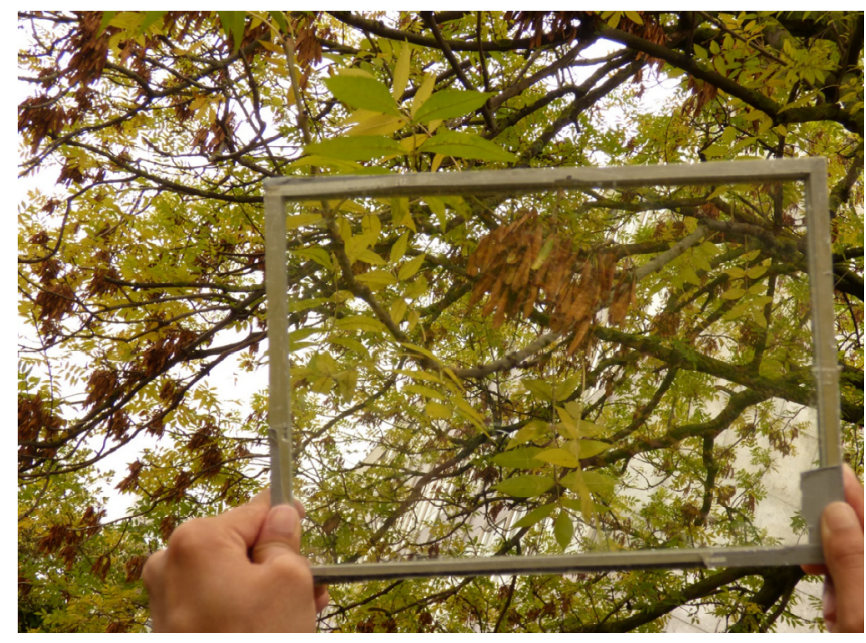

Fig. 3. Photographic view of an air-filled double-glazing.

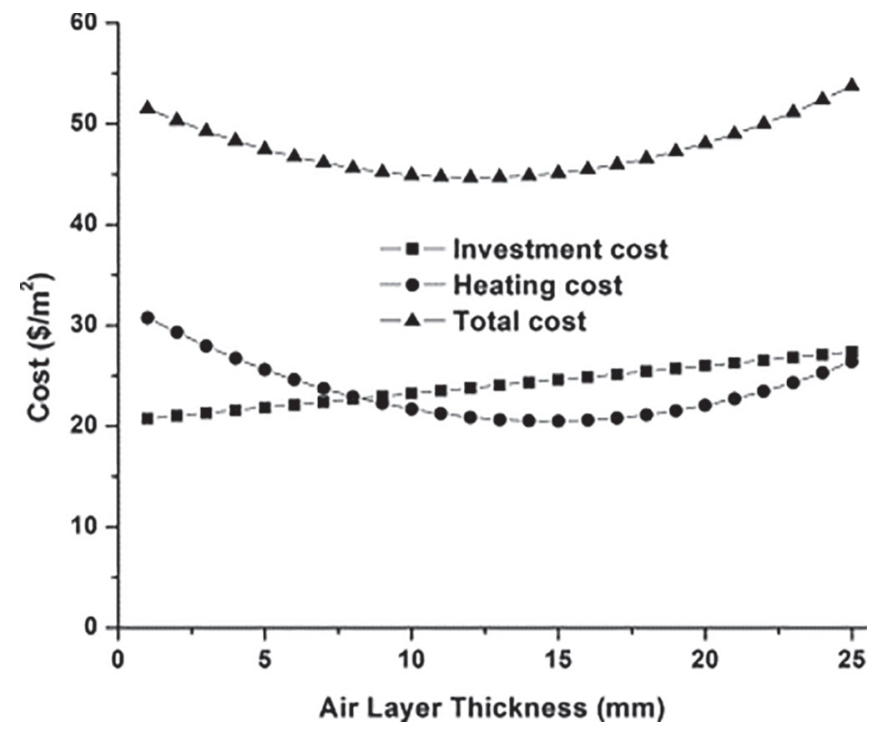

Fig. 4. Effect of air layer thickness on the costs for Iskenderun. (taken from Ref. [39]. 
exchange between opposite glass surfaces in the window. The SHGC can also be varied by alternating the transmittance of the glass panes [45]. Due to higher visible transmission, daylight and glare control using double glazing is not possible. External or internal shading devices are required to obtain control over incoming daylight.

\subsection{Low emissivity (low $-e$ ) coated double glazing}

To reduce building cooling and heating load, reduction of entering solar radiation in summer and reduction of heat transfer from indoor to external environment in winter is essential. Incident solar radiation on a double-glazing transmits, reflects and absorbed by the glass surface. According to Kirchhoff law of thermal radiation, energy absorbed by an opaque material must be equal to emitted energy. Thus, emittance will be equal to absorbance. Higher emittance enhances the radiative heat transfer. Radiative heat from a material relative to a blackbody (emissivity 1 ) is categorised as emissivity and its value varies from 0 to 1 [46]. Inclusion of low emissivity (Low-e) coating reduces the thermal radiation from a glass surface. For double glazing, low-e coating applied on the internal surface of the inside glass pane reduces the heat loss from interior room to an exterior environment. While low-e coating applied on the internal surface of the outside glass pane of a double glazing, it limits to enter the infrared spectrum (or long wave spectrum) of the incident radiation [22] [47]. Low-e coatings are metals or metallic oxide spectrally selective coatings which allow visible light in the solar spectrum to be transmitted $[48,49]$ and reflect the infrared $(2000 \mathrm{~nm}-50,000 \mathrm{~nm})$ [50,51]. Low-e coating for glazing should exhibit high transmission in the visible wavelength; emittance value should be low to restrict heat transmission from room and should have high durability under solar exposure. The operation of a low-e coated double-glazing is shown in Fig. 5. Soft low-e coatings to provide higher transparency and higher infrared reflection, though extra protective layers are required to provide durability [50,52-54]. Silver, gold, and aluminium low-e coating have low absorption coefficients of $5 \%, 8 \%$ and $30 \%$ respectively. As silver has poor stability to atmospheric moisture, silver coatings are protected using a dielectric layer of zinc, tin or titanium. Available low-e coatings have been reviewed extensively [34].

\subsection{Prismatic glazing}

Prismatic glazing reflects direct solar radiation whilst allows diffuse solar radiation enters into a building. Prismatic glazing consists two prismatic panes inclined within the window plane, positioned facing each other, with a small gap between the two

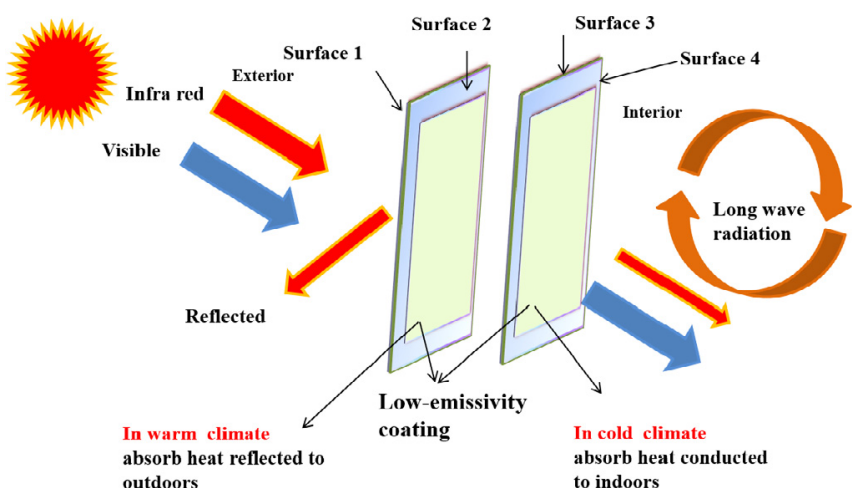

Fig. 5. Operation of low-emissivity coated double-glazing.

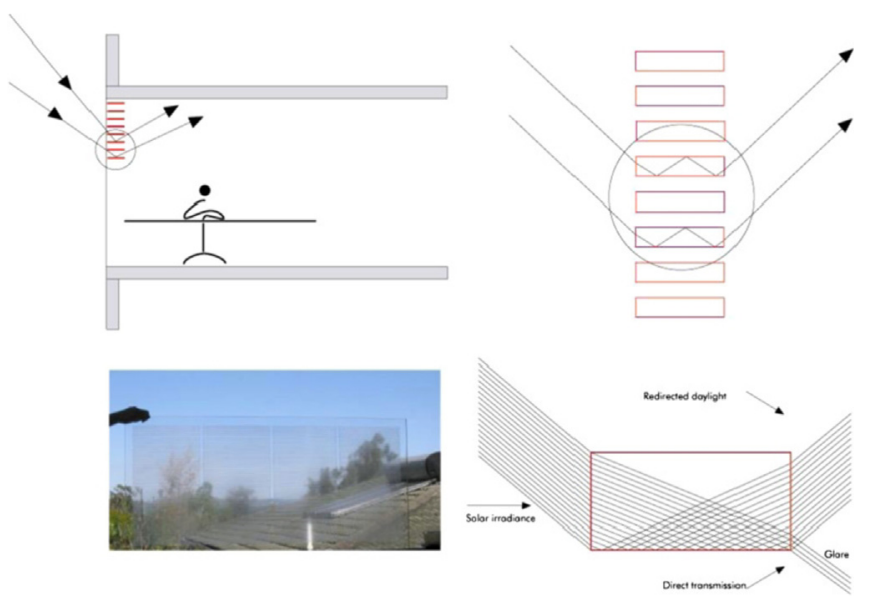

Fig. 6. Schematic and details of prismatic glazing. Reprinted from Ref. [57] with permission from Elsevier.

panes as shown in Fig. 6. The lower rib faces of the outer prismatic pane are coated with a specularly reflecting layer and the upper rib faces of the inner prismatic pane are coated with a diffusely reflecting layer. The prismatic glazing unit can be used for common window with significant solar gains in temperate climates to achieve relatively uniform daylight illumination of a room. The reflecting surfaces of the prismatic ribs do not create glare [55]. A fully functional dynamic prismatic optical element coating combined with conventional vertical daylight strategies, can reduce electric lighting demand by $85 \%$. In an another work, prismatic glazing decreased $10 \%$ incident direct solar radiation onto the front of a building whilst allowed $90 \%$ radiation in winter [56].

\subsection{Water flow glazing}

A water-flow glazing contains clean water to flow upward or downward between two glass panes as shown in Fig. 7. Water flow between two glass panes lowers the glass pane temperature and solar heat gain entering the room [58]. Thus, the cooling load due to air-conditioning is reduced. The water-flow between the glass

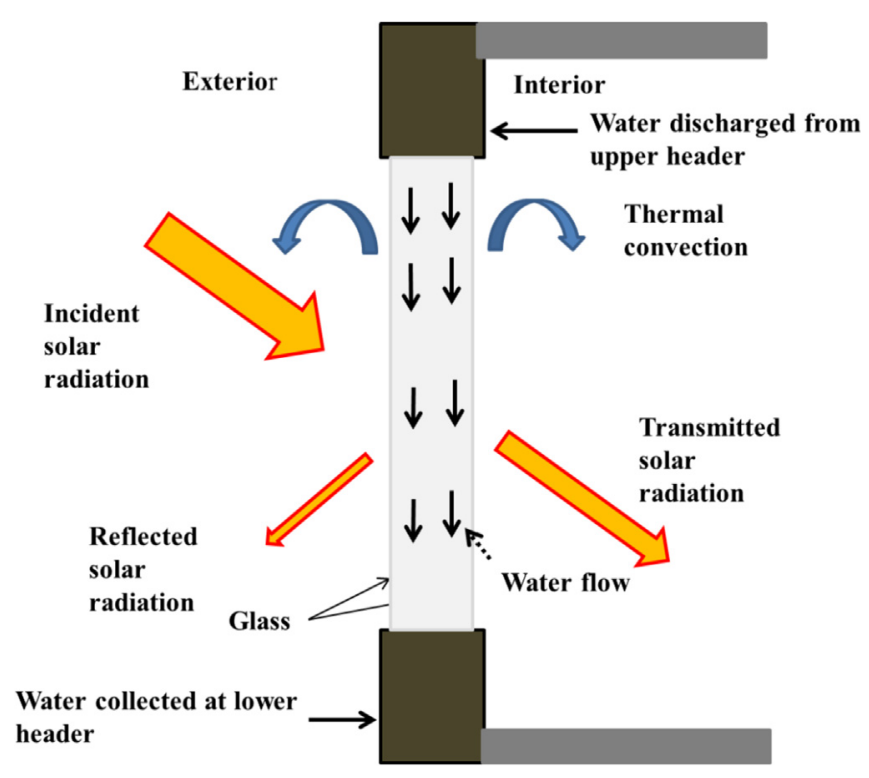

Fig. 7. Energy flow path at water flow glazing. 
panes can be directed to a water heating system [59]. In China, $0.01 \mathrm{~m} / \mathrm{s}$ optimum water flow speed was able enough to maintain room temperature [60]. The total energy performance for water flow glazing is better in winter than summer as heat from indoor space is also be absorbed by water and reclaim by using hot water [61]. Compared to conventional double and single pane window this water flow window reduces $32 \%$ and 52\% annual room heat gain respectively. Water flow glazing is advantageous for combined performance such as reduction of air condition load and water heating [62]. Water flow inside a double-glazing can control more heat than airflow inside the double-glazing $[63,64]$ as water has higher density and heat capacity than air. For tropical Malaysian climate, water flow glazing showed $70 \%$ short wave infra-red $(1300 \mathrm{~nm}-2500 \mathrm{~nm})$ absorption which offered thermal comfort for building interior [65]. Water is natural, colourless, odourless, non-toxic, and plentiful and does not have any impact on visibility from room to outside. Disadvantages of this type of systems are laborious construction process and design requirement for auxiliary water collector, which may not be feasible for retrofitting window application or even in new zero energy building. Pumping systems are required to generate the water flow from lower header to upper header. The cost of water flow glazing installation is similar to a solar panel installation [66]. Control over glare and allowable daylight are not possible using this glazing. This system is not commercially available.

\subsection{Air flow glazing}

In an airflow glazing, space between inner and outer glazing surface is an airflow path as shown in Fig. 8 [67,68]. This glazing can reduce effective $U$-value up to $30-40 \%$ compared to air-filled double glazing [69]. Air is supplied in from outside or from the building either buoyancy or mechanical extraction process. Air between two glasses panes gets heated due to incoming solar radiation. Warmer air flows in to the room from the top of the glazing outlet [69-71]. Warmer air enhances to reduce the heating load and improves indoor space quality in winter and for cold climatic area. For summer area, the warmer air can be thrown away from the glazing, which will act as a barrier for direct entering solar heat gain. Air supply in a room and air exhaust from a room both in a same window is also possible [72,73]. For airflow glazing, reduction of $U$-value is possible by adding a low-e coating facing into the ventilated layer to increase pre-heat air. Pre-heat inclusion

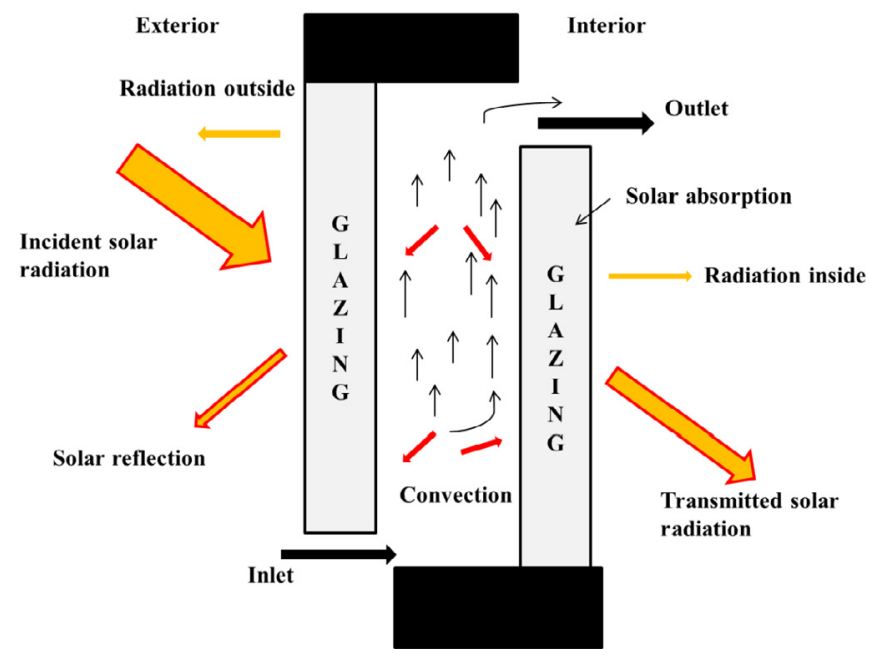

Fig. 8. Schematic diagram of the airflow glazing. increases $1-5 \%$ of the window-shading coefficient. Addition of double pane instead of single glass for inner glazing unit of an airflow glazing can offer low $U$-value $\left(2.2 \mathrm{~W} / \mathrm{m}^{2} \mathrm{~K}\right.$ to $\left.1.8 \mathrm{~W} / \mathrm{m}^{2} \mathrm{~K}\right)$ while speed of airflow increases $\left(20 \mathrm{~m}^{3} / \mathrm{h}\right.$ to $\left.80 \mathrm{~m}^{3} / \mathrm{h}\right)$ [74]. $U$-value of a triple pane supply air window can vary from $0.5 \mathrm{~W} / \mathrm{m}^{2} \mathrm{~K}$ to $0.1 \mathrm{~W} / \mathrm{m}^{2} \mathrm{~K}$ while airflow speed changes from $10 \mathrm{~m}^{3} / \mathrm{h}$ to $30 \mathrm{~m}^{3} / \mathrm{h}$ [75]. This is $54 \%$ reduction of $U$-value than a classical triple glazing $\left(1.1 \mathrm{~W} / \mathrm{m}^{2} \mathrm{~K}\right)$. Airflow glazings need a fan to collect and flow the air between the glazing panes and require internal cleaning as presence of dust in the air can create scatter and reduce the visibility through the glazing. Glare and daylight control are not achievable using airflow glazing. This is also not commercially available.

\subsection{Vacuum glazing}

Vacuum glazing is a highly thermally insulated glazing, which can offer high transmittance. Vacuum glazing consists vacuum between two glass panes. To maintain pane separation against outside atmospheric pressure, small support pillars are employed between two glass panes. This support pillars are negligible and do not create any viewing obstacle [76]. Vacuum glazing, shown in Fig. 9 has a hermetic (leak free) edge sealing around the periphery of two glass sheets and a stable pressure $(<0.1 \mathrm{~Pa})$ between two glass sheets [77-79]. Vacuum glazing works on the principle of thermal insulation by eliminating any gaseous medium for convective heat transfer as in the Dewar flask (1893), was proposed by Zoller in 1913 with a patent granted in 1924 [78]. Transmission spectra of a vacuum glazing are shown in Fig. 10. It can be seen that long-wave transmission is restricted due to the presence of low-e coating [80,81].

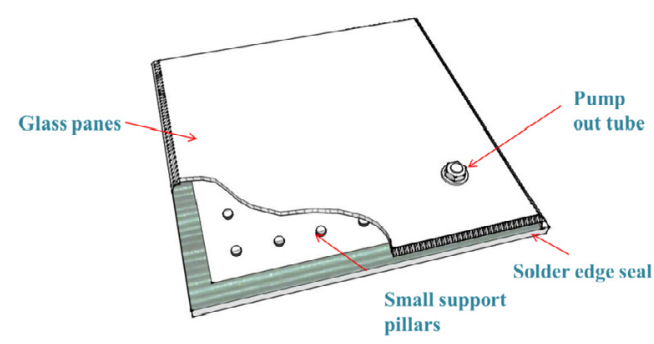

(a) Top view

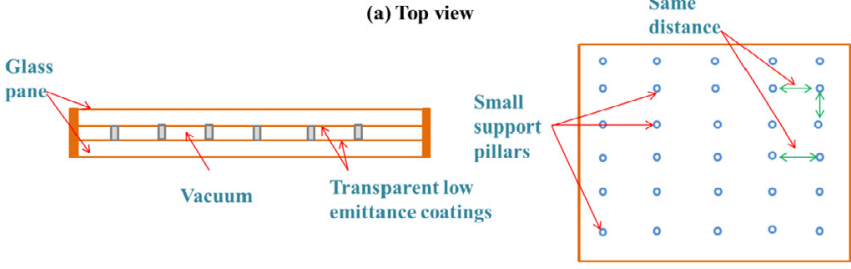

(b) Cross sectional view

(c) Details of support pillars position

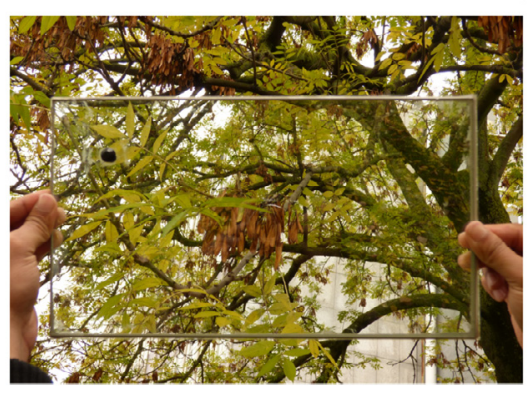

(d) Viewing through vacuum glazing

Fig. 9. (a), (b), (c) details of vacuum glazing and (d) photographic view of a vacuum glazing. Reprinted from Ref. [80] with permission from Elsevier Ltd. 


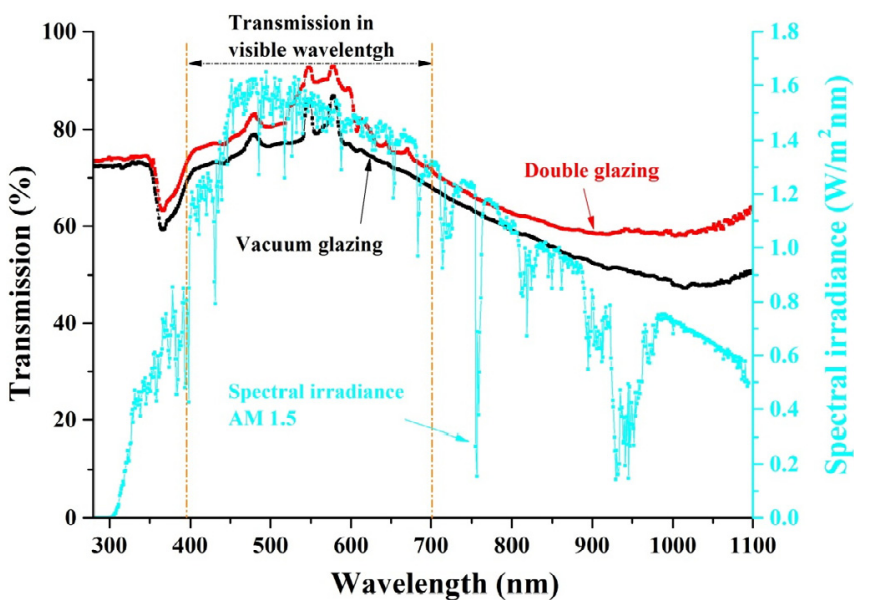

Fig. 10. Transmission spectra of a (i) SPACIA vacuum glazing sample coating of the two glass panes with one low-emittance coating, (ii) double glazing and (iii) AM 1.5 solar spectral irradiance. Reprinted from Ref. [80] with permission from Elsevier Ltd.

The first successful vacuum glazing fabrication process was achieved using solder glass edge sealing at above $450^{\circ} \mathrm{C}$ [82-84] in 1989. Since then, many samples of vacuum glazing with $U$-value of $0.8 \mathrm{~W} / \mathrm{m}^{2} \mathrm{~K}$ using a solder glass edge sealing technique were fabricated. Addition of transparent low-e coating reduces radiative heat transfer between the panes [85]. High temperature vacuum glazing fabrication can cause performance degradation of soft lowe coatings. To enable lower emittance, soft coating is essential to lower overall heat loss. Low temperature edge seal fabrication (less than $200^{\circ} \mathrm{C}$ ) method using indium alloy was developed [86,87] for vacuum glazing with measured thermal transmittance less than $1 \mathrm{~W} / \mathrm{m}^{2} \mathrm{~K}$ for the centre-of-glass area $[88,89]$. Use of two low-e coatings does not reduce the overall heat transfer rate over a single low-e coating layer. One layer of low-e coating also reduces the overall system cost, as low-e coatings are costly [90]. Edge sealing, framing and glass pane thickness has direct effect on the thermal performance of vacuum glazing. In vacuum glazing, the edge seal allows heat flows from the glass sheet on the warm side through the edge seal to the sheet on the cold side, which decrease the overall thermal performance of the glazing. Thus, edge seal in vacuum glazing works as short circuit between two glass sheets [85]. However, scarcity and cost of indium can be challenging for advancing of indium edge sealed vacuum glazing. Thus, Cerasolzer type CS186 was investigated on vacuum glazing at University of Loughborough for replacement of indium edge sealing [91-93]. Metal-based array of opaque small pillars was also replaced by transparent pillars, which were prepared by using $76 \mathrm{wt} \%$ low melting glass powder and $24 \mathrm{wt} \%$ ethyl cellulose terpineol solution. These small pillars showed higher transmittance, higher vickers hardness, uniform thickness compared to metal one [94]. Frame in vacuum glazing should provide high thermal insulation and maintain the structural strength. An insulating frame for vacuum glazing reduces the $U$-value of vacuum glazing. It also offers high temperature of the glass at the edge to the entire glazing [88]. For vacuum glazing, one exoskeleton structure made from Aluminium was investigated. Exoskeleton structure can be made by wood, polypropylene or polyethylene polyvinylchloride, with a range of solid thermal insulations filling the internal cavities. Experiment and simulation work showed that increase of thickness of the frame decreased the rate of increases of $U$-value [88]. Though vacuum glazing is in research interest from last three decades, few works were undertaken at outdoor conditions. At University of Sydney, vacuum glazing was exposed from October 1995 to June 1996 for investigation of its long-term mechanical and thermal integrity performance [95]. At Dublin Institute of Technology, this glazing was performed from July to November 2014 to investigate its $U$ value and daylight performance. It was found that this glazing offered 53\% reduction of heat losses compared to a similar area of double-glazing where daylight penetration through both glazing was nearly equal. SHGC for vacuum glazing was found to be 0.58 while incident angle was $42^{\circ}$ [80]. Table 1 shows the detail of different type of investigated vacuum glazing. It is evident that $U$ value for vacuum glazing is the most available data. However, from Ghosh et al. [80] work, it can be concluded that vacuum glazing allows sufficient solar heat gain and control heat loss but enhances the possibility of glare.

To obtain much lower overall heat transfer coefficient triple vacuum glazing (shown in Fig. 11) was studied theoretically [96,97]. From simulation study, it was found that triple vacuum glazing can offer $U$-value of $0.2 \mathrm{~W} / \mathrm{m}^{2} \mathrm{~K}$ which lowered $60 \%$ heat loss compared to double pane vacuum glazing. However, manufacturing of triple vacuum glazing and indoor-outdoor experiment is required to proof the concept.

For vacuum glazing application, the best suitable locations are

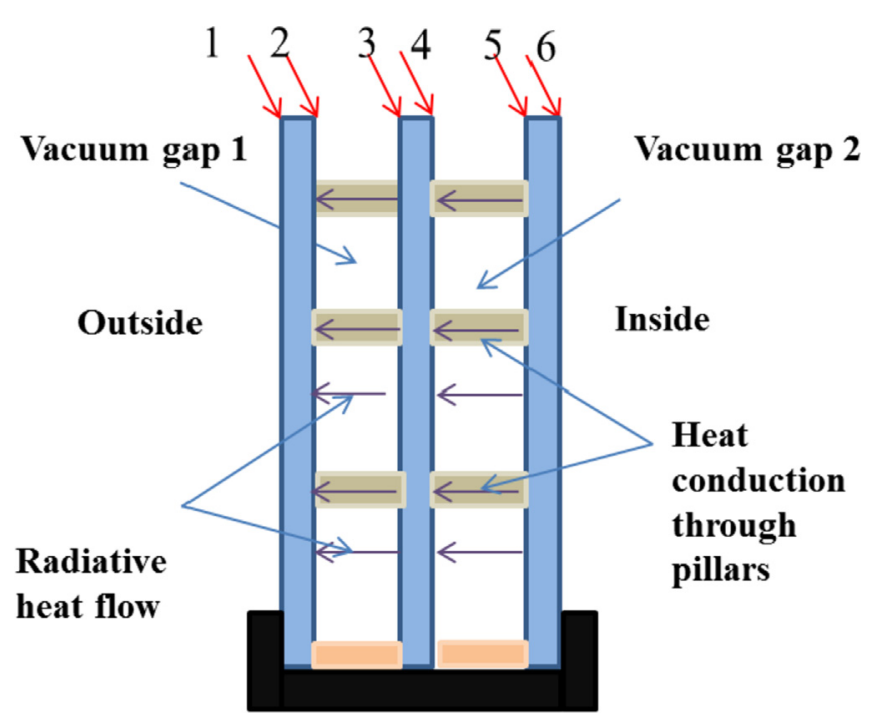

Fig. 11. Schematic diagram of triple vacuum glazing and heat flow across the triple vacuum glazing (Redrawn from Ref. [98]).

Table 1

Literature data for Vacuum glazing.

\begin{tabular}{|c|c|c|c|c|c|}
\hline Dimension & $U$-value $\left(W / m^{2} K\right)$ & SHGC & Transmission & Remarks & Reference \\
\hline $1 \mathrm{~m} \times 1 \mathrm{~m}$ & 0.8 (solder glass edge sealing) & Not available & Not available & $U-$ value was found using indoor experiment & [85] \\
\hline $0.4 \mathrm{~m} \times 0.4 \mathrm{~m}$ & 0.97 (indium alloy edge sealing) & Not available & Not available & $U$-value was found using indoor experiment & [89] \\
\hline $0.5 \mathrm{~m} \times 0.5 \mathrm{~m}$ & & & & & \\
\hline $0.35 \mathrm{~m} \times 0.21 \mathrm{~m}$ & 1.4 (NSG SPACIA) & 0.58 & $72 \%$ (visible) & $\begin{array}{l}U \text {-value was found outdoor experiment } \\
53 \% \text { heating load saving }\end{array}$ & [80] \\
\hline
\end{tabular}


cold climatic area where heating load demand is high. Vacuum glazing will stop the heat transmission from room to external environment and reduce the heating cost. In warm climate, this glazing may work as heat insulator and increase the cooling load demand. Different optical and thermal parameters of investigated vacuum glazing has been summarised in Table 1 .

\subsection{Aerogel glazing}

Aerogels are air permeable dried gels with a very high porosity, which make it to have lower thermal conductivity than air [99]. They are nontoxic, low flammable, lightweight, low refractive index [100], high specific surface area and low apparent density [101,102]. Aerogels can provide acoustic insulation and fire-extinguishing ability. Aerogels can be formed from silica, alumina, and carbon or from transition and lanthanide metal oxides, metal chalcogenides, and organic/inorganic polymers. Silica aerogel is the most common, being formed by aggregations of silica nanoparticles having 5-10 nm diameter and $50 \mathrm{~nm}$ diameters of mesoporous air voids [103]. Granules are irregular in shape and millimetres in size. Pore diameter of silica aerogel varies between 10 and $100 \mathrm{~nm}$ and this air void path is smaller than mean free path of nitrogen and oxygen and from other aerogel material. Small pore size in aerogel reduces heat flow due to conduction. Thus, aerogel has low thermal conductivity between 0.005 and $0.02 \mathrm{~W} / \mathrm{m} \mathrm{K}$ and act as barrier for thermal conduction [104]. Aerogel is infrared permeable and offer higher thermal conductivity at higher temperature [105,106]. Addition of carbon black, titanium di oxide $\left(\mathrm{TiO}_{2}\right)$ or zinc oxide ( $\mathrm{ZnO})$ helps aerogel to scatter the infrared, lowering radiation heat transfer and improving thermal conductivity [107].

Monolithic and granular are the two types of available silica aerogel. Manufacturing of large pieces of monolithic silica aerogels is troublesome due to aerogel's fragile nature. In comparison, monolithic silica aerogel $\left(0.063 \mathrm{~W} / \mathrm{m}^{2} \mathrm{~K}, 60 \%\right.$ transparent between two glass panes) has better thermal conductivity and optical transmittance than granular $\left(1 \mathrm{~W} / \mathrm{m}^{2} \mathrm{~K}\right.$ and 30\%) [108-110]. Monolithic transparent aerogels are attractive for glazing application [111] though presently no commercial products are available because of the costly and time-consuming synthesis process. Translucent granular silica aerogels can be defined as nanogels, are suitable for highly energy-efficient windows and skylights. Nanogel filled double glazing can reduce $21 \%$ total energy consumption for heating (12\%) cooling (5\%) and lighting (4\%) compared to air double-glazing in Oslo Norway [112]. Silica aerogel from Cabot Corporation had transmittance 0.45 which reduced $4-8 \%$ spaced cooling load compared to a 0.9 transmittance double-glazing [105]. Table 2 mentioned the list of aerogel glazing has been examined. Fig. 12 shows photographic view of aerogel material and aerogel glazing. Spectral transmission of aerogel is shown in Fig. 13.

Edge sealing of aerogel glazing is difficult due to fragility of aerogel. To achieve low thermal performance of aerogel glazing, edge sealing should have lower thermal conduction, airtight and

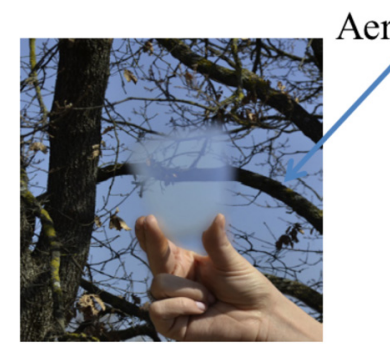

(a)

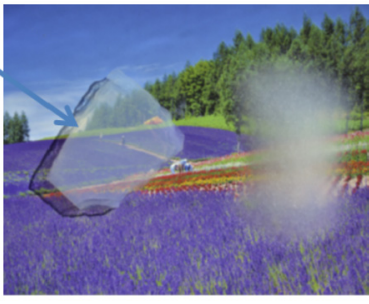

(b)

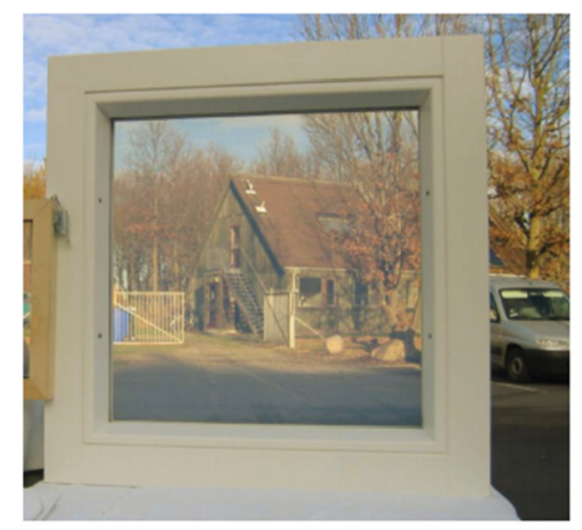

(c)

Fig. 12. (a) Viewing through an aerogel sample, (b) monolithic and granular aerogel, (c) an evacuated aerogel glazing in a well-insulated frame. Reprinted from Refs. $[108,111]$ with permission from Elsevier.

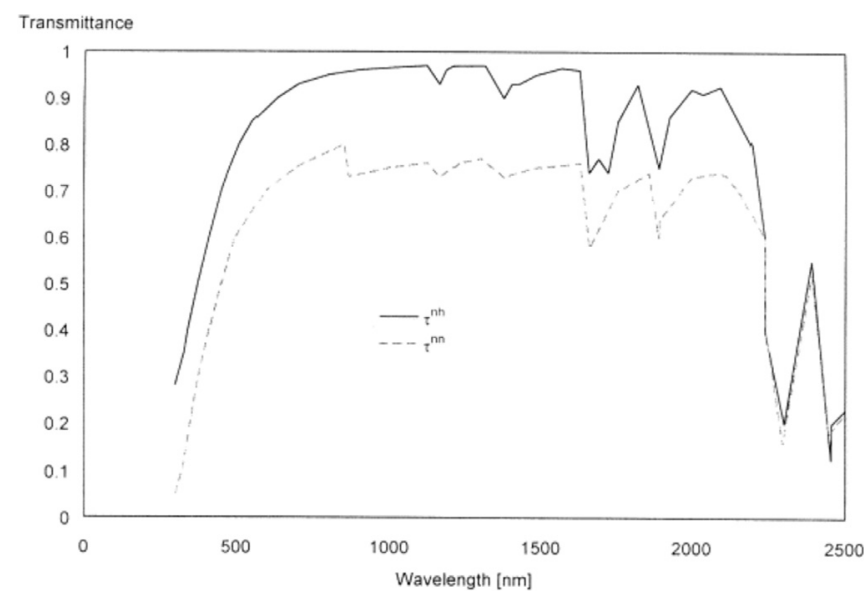

Fig. 13. Spectral normal hemispherical and normal transmittance of aerogel with density $90 \mathrm{~kg} / \mathrm{m}^{3}$ and thickness $12 \mathrm{~mm}$. Reprinted from Ref. [116] with permission from Elsevier Ltd.

Table 2

Literature data for Aerogel glazings.

\begin{tabular}{|c|c|c|c|c|c|c|}
\hline & & Dimension & $U$-value & Transmission & Thickness & Reference \\
\hline \multirow[t]{8}{*}{ Type } & Monolithic silica aerogel & $55 \times 55 \mathrm{~cm}^{2}$ & $0.72 \mathrm{~W} / \mathrm{m}^{2} \mathrm{~K}$ & $73-75 \%$ & $15 \pm 1 \% \mathrm{~mm}$ & [113] \\
\hline & Monolithic silica aerogel & $0.58 \times 0.58 \mathrm{~m}^{2}$ & $0.66 \mathrm{~W} / \mathrm{m}^{2} \mathrm{~K}$ & $76-80 \%$ & $15 \mathrm{~mm}$ & [111] \\
\hline & Monolithic Silica aerogel & $55 \times 55 \mathrm{~cm}^{2}$ & $0.7 \mathrm{~W} / \mathrm{m}^{2} \mathrm{~K}$ & $76 \%$ & $15 \mathrm{~mm}$ & [114] \\
\hline & Silica aerogel & $7.5 \times 25 \mathrm{~cm}^{2}$ & & $90 \%$ & $10 \mathrm{~mm}$ & [115] \\
\hline & Monolithic Silica aerogel & a) $0.5 \times 0.5\left(\mathrm{~m}^{2}\right)$ & $0.40 \mathrm{~W} / \mathrm{m}^{2} \mathrm{~K}$ & & & [116] \\
\hline & & b) $1.0 \times 1.0$ & & & & \\
\hline & & c) $1.5 \times 1.5$ & & & & \\
\hline & Granular silica aerogels & NA & $0.4 \mathrm{~W} /\left(\mathrm{m}^{2} \mathrm{~K}\right)$ & $35 \%$ & $20 \mathrm{~mm}$ & [117] \\
\hline
\end{tabular}


have enough strength to hold the two glass panes. Jensen et al. [113] mentioned polystyrene support based edge sealing for monolithic type aerogel granules sandwiched between glass panes. Reim et al. [117-119] used two glass panes filled with insulating granular silica aerogel. Huang and Niu [105,120] used an aluminium bracket to support glass cover and on the bracket-sealed surfaces, polystyrene was employed with sealant. As the fragility of silica aerogel limits their application, mechanical strength enhancement of silica aerogel has been achieved by incorporating a polymer. Silica aerogel scatters the transmitted light, which is a major barrier to production of transparent aerogel glazing. Light reflected off silica aerogels has a blue colour; hence, it is called "frozen smoke" [116,121]. Aerogels are available commercially (ASPEN aerogel) mainly for building wall insulation rather than specifically for glazing application. The scattering properties of silica aerogel can be overcome by using it as a spandrel component in a façade [122-124] to allow daylight through spandrels.

\subsection{Photovoltaic glazing}

In Photovoltaic (PV) glazing, organic or inorganic type PV cells are placed between the two glass panes. PV glazing reduces glazing transparency, reducing the solar heat gain coefficient (SHGC), which reduces the cooling load, and introduces daylighting control as shown in Fig. 14 [125-127]. Another advantage of this type of glazing is that the PV provides small-scale electricity generation [128]. The presence of low-e coating reduces the heat transfer through radiation process [48]. PV glazing can be a part of buildingintegrated photovoltaic (BIPV) [129] widely used as façades or roof [130]. Triple-point (maintaining day-lighting, reducing overall heat transfer value and generating clean electricity) effect is possible to be attributed by PV glazing.

Charron and Athienitis [132] reported a double glazing system with integrated PV and motorized blind in which the lower part of the facades was with PV and upper part was motorized blind. When PV was installed in the middle of the cavity, electrical generation reduced $21 \%$ though overall thermal and electrical efficiency increased 25\%. Manually adjusted photovoltaic slat window (PV$\mathrm{SW}$ ) with $0.5 \times 0.6 \mathrm{~m}^{2}$ surface areas, offered power generation of $15 \mathrm{~W}$. Illuminance inside the test cell was 750 lux while window had $68^{0}$-slat angle [133]. Area of PV cell has significant effect to reduce the solar gain. Theoretical and experimental work of new spaced type semi-transparent PV module offered $70 \%$ solar heat gain if $80 \%$ glazing area is covered by solar cell. PV cell efficiency and material thickness had no effect on solar heat gain control [134]. In a building, 40\% transmittance PV glazing offered minimum electricity consumption of a building while window to wall ratio (WWR) was 50\% [135]. Energy savings of 16.7-41.3\% were achieved in Singapore for a WWR range of 70-100\% [128]. Double-glazing

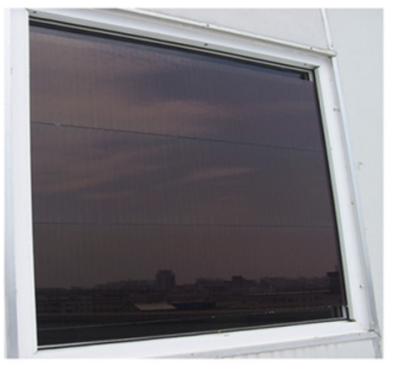

(a)

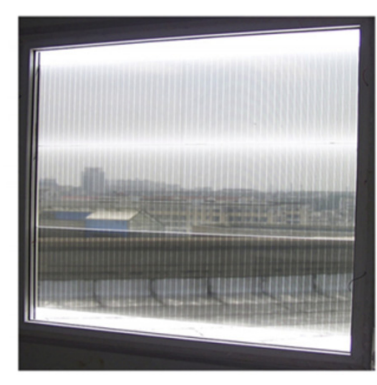

(b)
Fig. 14. (a) Double glazing (b) Single glazing PV (semi-transparent amorphous silicon) window. Reprinted from Ref. [131] with permission from Elsevier. achieved superior performance compared to PV single glazing under Singapore climatic condition due to single glazing's less solar heat gain control [128]. In hot climatic area, a see through PV cell ventilated glazing was able to save $23 \%$ electricity saving in the space cooling for a year [136,137]. A new PV glazing consist of transparent a-Si PV, integrated with $\mathrm{TiO}_{2}$ nano coating offered $7 \%$ higher power generation than conventional PV glazing. This type of glazing offers high insulation, power generation and self-cleaning due to nanocoating [138-140]. Dye-sensitized solar cells (DSSC) [141-146] and perovskite [147,148] based PV glazing are also currently under investigation. However stability under outdoor ambient conditions needs to be established before considering them for glazing application [149] [150]. Spectral transmission of DSSC glazing for different thickness of titanium dioxide layer is shown in Fig. 15. Table 3 shows thermal and optical parameters for different investigated PV glazing. Higher absorption of PV offers low visible transmission, which is suitable for glare control. However, this lower value also reduce the viewing and allowable daylight for building interior. Recently cadmium telluride (CdTe) thin film based PV glazing was investigated for building in Indian [151] and Brazilian [152] climate and satisfactory results were found. Difference of $U$-value between PV single glazing and PV double glazing is four times.

Table 4 summarised the glazing properties for constant or static transparent glazing systems. It is evident that these types of glazing systems are not able to offer control over heat transfer coefficient, solar heat gain, and daylight and glare in a single unit.

\section{Non electrically actuated switchable material}

This section introduces switchable glazings, which are activated by non-electrical impulses. Thermochromic, thermotropic, phase change material and gasochromic are the non-electrically actuated switchable glazing. Switchable glazing changes its transparency from transparent/bleaching state to opaque/coloured/translucent state or reverse depends on actuation. More than one transparency makes them attractive for glazing application as they can adapt with buildings demand. Switchable glazings are primarily responsible to control solar heat gain and introduce comfortable daylight.
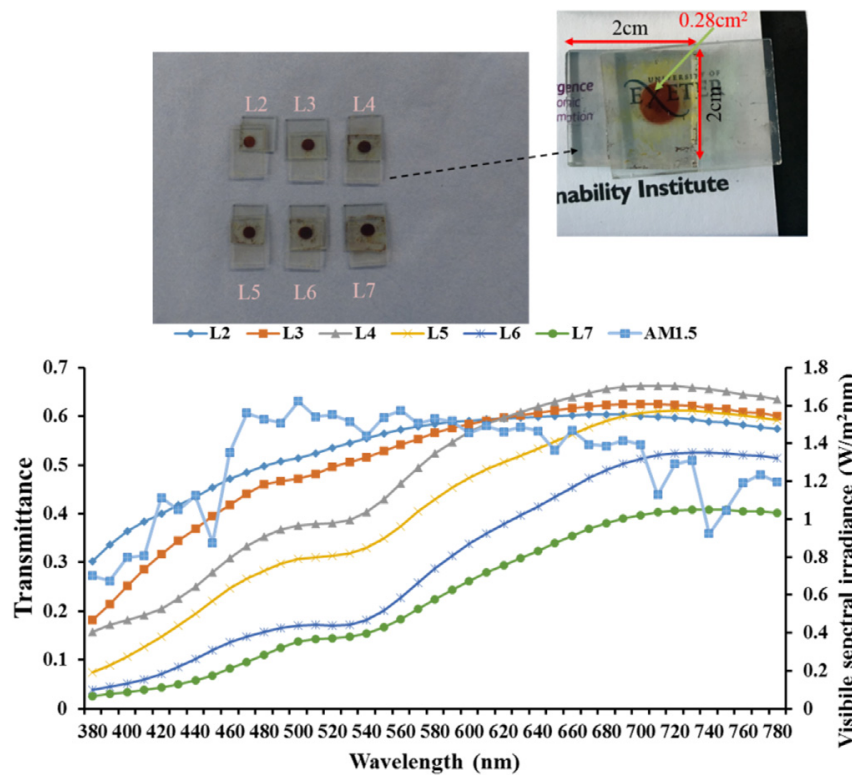

Fig. 15. Spectral transmittance of DSSC glazing where L2, L3, L4, L5, L6, L7 indicates $3 \mu \mathrm{m}, 0.5 \mu \mathrm{m}, 6 \mu \mathrm{m}, 8 \mu \mathrm{m}, 10 \mu \mathrm{m}, 12 \mu \mathrm{m}, 14 \mu \mathrm{m}$ thick $\mathrm{TiO}_{2}$ layer [153]. 
Table 3

Literature data for PV glazings.

\begin{tabular}{|c|c|c|c|c|c|}
\hline Dimension $(\mathrm{m} \times \mathrm{m})$ & Type of PV & $U$-value $\left(\mathrm{W} / \mathrm{m}^{2} \mathrm{~K}\right)$ & SHGC & Visible transmission (\%) & Reference \\
\hline $0.98 \times 0.95$ & a-Si single glazing & 5.08 & 0.289 & 9.17 & [128] \\
\hline $1.3 \times 1.1$ & micromorph-Si single glazing & 4.80 & 0.413 & 5.19 & [128] \\
\hline $0.98 \times 0.93$ & a-Si double glazing & 1.67 & 0.154 & 6.91 & [128] \\
\hline
\end{tabular}

Table 4

Glazing parameters control using static or constant transparent glazing.

\begin{tabular}{|c|c|c|c|}
\hline Static or constant transparent glazing & $\begin{array}{l}\text { Control of overall heat } \\
\text { transfer coefficient ( } U \text {-value) } \mathrm{W} / \mathrm{m}^{2} \mathrm{~K}\end{array}$ & $\begin{array}{l}\text { Control of solar heat gain } \\
\text { coefficient (SHGC) }\end{array}$ & Control of daylight/glare \\
\hline Double glazing (made by clear glass) & $\checkmark$ & $\times$ & $x$ \\
\hline Low-e coated double glazing & $\checkmark$ & $\checkmark$ & $\times$ \\
\hline Prismatic glazing & $\times$ & $\checkmark$ & $\checkmark$ \\
\hline Water flow glazing & $\times$ & $\checkmark$ & $\times$ \\
\hline Air flow glazing & $\checkmark$ & $\checkmark$ & $\times$ \\
\hline Vacuum glazing & $\checkmark$ & $\checkmark$ & $\times$ \\
\hline Aerogel glazing & $\checkmark$ & $\times$ & $\checkmark$ \\
\hline PV glazing & $\times$ & $\checkmark$ & $\checkmark$ \\
\hline
\end{tabular}

\subsection{Thermochromic}

Thermochromic material changes its colour by changing its crystal structure above a particular environmental temperature [154-158]. Thermochromic materials can be inorganic and polymer based. Other thermochromic materials include iron oxide $\left(\mathrm{Fe}_{3} \mathrm{O}_{4}\right)$, iron silicide $\left(\mathrm{FeSi}_{2}\right)$, niobium dioxide $\left(\mathrm{NbO}_{2}\right)$, nickel sulphide (NiS), and titanium oxide $\left(\mathrm{Ti}_{2} \mathrm{O}_{3} ; \mathrm{Ti}_{4} \mathrm{O}_{7} ; \mathrm{Ti}_{5} \mathrm{O}_{9}\right)$. Inorganic vanadium dioxide $\left(\mathrm{VO}_{2}\right)$ thermochromic glazing has a $68^{\circ} \mathrm{C}$ transition temperature $\left(T_{C}\right)$ [158]. Below this $T_{C}$, it behaves like insulator and infrared transparent and above the $T_{C}$ it behaves like metal and reflects infrared. This phase change from metal to insulator occurs within $10-12 \mathrm{~s}$. $\mathrm{VO}_{2}$ thin film made by two different precursor gels, $\mathrm{V}-\mathrm{H}_{2} \mathrm{O}_{2}\left(\mathrm{~V}_{2} \mathrm{O}_{5} .2 .2 \mathrm{H}_{2} \mathrm{O}\right)$ and $\mathrm{V}_{2} \mathrm{O}_{5}-\mathrm{H}_{2} \mathrm{O}_{2}$ $\left(\mathrm{V}_{2} \mathrm{O}_{5} \cdot 1.8 \mathrm{H}_{2} \mathrm{O}\right)$ and one step annealing at $750^{\circ} \mathrm{C}$ in a vacuum can reduce the transition temperature from $68^{\circ} \mathrm{C}$ to $62.5^{\circ} \mathrm{C}$ [159]. Thermochromic dye BW 100 based thermochromic coatings were coated on glass substrate, which showed coloured phase at $20^{\circ} \mathrm{C}$ and colour less phase at $30^{\circ} \mathrm{C}$. It was also found that addition of $\mathrm{TiO}_{2}$ enhance the reflectance of this coating. Colourless phase showed higher visible and infra-red reflectance than coloured phase [160]. A thermochromic glazing is shown in Fig. 16. Spectral behaviour of thermochromic $\mathrm{VO}_{2}$ film is shown in Fig. 17.

As its operation requires neither external power nor control devices, can lower $\mathrm{VO}_{2}$ transition temperature by doping with valence metal dopant like tungsten (W6+), molybdenum (Mo6+), tantalum ( $\mathrm{Ta} 5+)$, niobium (Nb5+) and ruthenium (Ru5+). Magnesium $(\mathrm{Mg} 2+)$ doping increases the visual spectral transmissivity whilst decreasing the transmission temperature. Tungsten doping

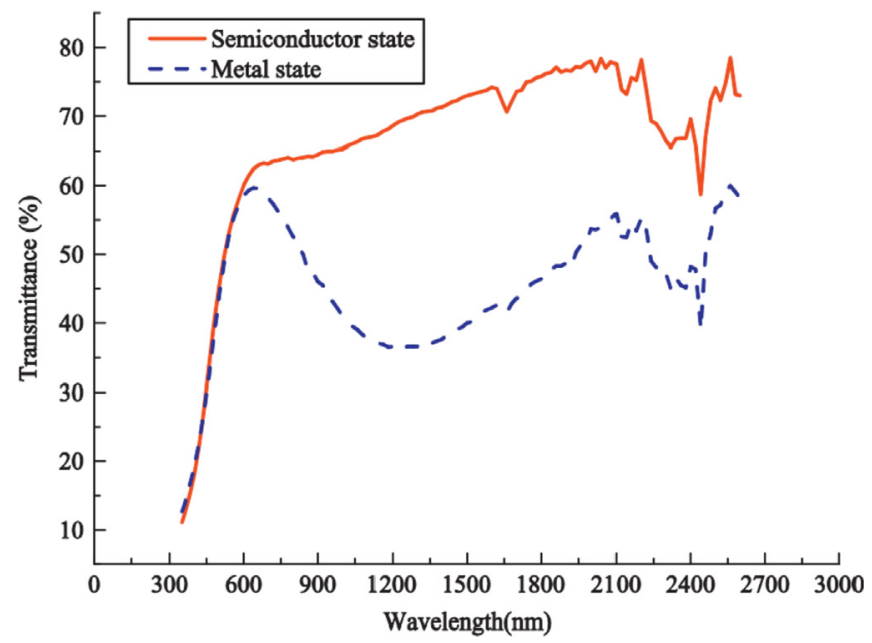

Fig. 17. Spectral transmittance of $\mathrm{VO}_{2}$ film. Reprinted from Ref. [47] with permission from Elsevier.

reduces the metal-semiconductor transition of $\mathrm{VO}_{2}$ to about $25^{\circ} \mathrm{C}$. $\mathrm{VO}_{2}$ film having low transition temperature $30^{\circ} \mathrm{C}$ was also reported [162]. Decrease of transition temperature and better transmission is possible using vanadium oxyfluoride (VOxFy). A polymer thermochromic was experimentally characterised in an outside environment, was found transition temperatures between $25^{\circ} \mathrm{C}$ to $74^{\circ} \mathrm{C}$ [161]. Adding an antireflection coating can increase the
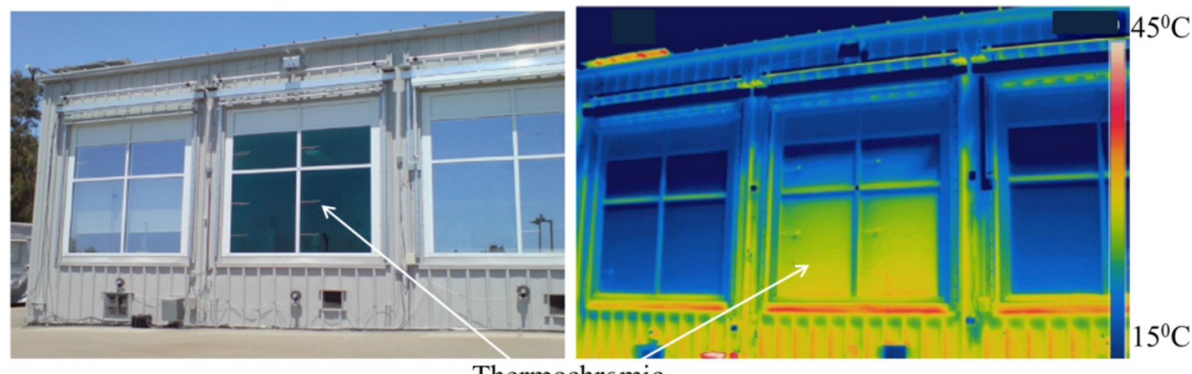

Thermochromic

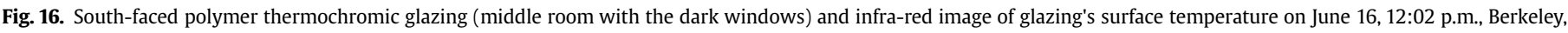
California $\left(37.91^{\circ} \mathrm{N}\right)$. Reprinted from Ref. [161] with permission from Elsevier. 
transmission at the visible wavelengths [163]. To obtain higher solar and luminous transmittance nanothermochromism is a possible way. $\mathrm{VO}_{2}$ nano particles dispersed in a dielectric host have higher luminous and solar transmittance than $\mathrm{VO}_{2}$ in continuous thin solid film [164]. Addition of gold nanoparticle changes the yellow-brown colour film to a variety of greens and blues and can be reflective for infra-red (IR). Colour changes and reflection percentage depends on the concentration of the gold nano particle [165].

First outdoor characterisation of thermochromic $\left(\mathrm{VO}_{2}\right)$ single glazing with a transition temperature $\left(\mathrm{T}_{\mathrm{C}}\right)$ of $41.3^{\circ} \mathrm{C}$ was performed [155]. Using outdoor data, simulation results showed that this glazing could save $15 \pm 5 \%$ cooling energy for low mass room and nearly $9.4 \%$ cooling energy consumption for a residential room. These results enhance the possibility of the adoption of the $\mathrm{VO}_{2}$ glazing for improving the thermal comfort and decrease the energy consumption in a passive building and an active building respectively [155]. First thermochromic double-glazed window was experimentally characterised using south facing outdoor low-mass test cell dimension of $2.9 \mathrm{~m} \times 1.8 \mathrm{~m} \times 1.8 \mathrm{~m}$ at the campus of the University of Science and Technology of China, Hefei, China. Results were compared with ordinary double glazing which showed that use of thermochromic double glazing saved $11.1 \%$ cooling energy demand. Using same meteorological data and BuildingEnergy simulation tool, performance of thermochromic single glazing was evaluated which showed that double glazing saves 23\% higher cooling load demand due to its lower visible and solar transmittance than single glazing [166]. Using same test cell, $25 \mathrm{~mm}$ thick paraffin wax with graphite foam based PCM plates were employed over the floor. Indoor test cell temperature with $\mathrm{PCM}+\mathrm{VO}_{2}$ was $45^{\circ} \mathrm{C}$ while without $\mathrm{PCM}+\mathrm{VO}_{2}$ the test cell room temperature was $68^{\circ} \mathrm{C}$. Interior thermal comfort using combined material was even better compared to a solo material application [167]. One hypothetical thermochromic glazing having solar transmittance range of $0.10-0.50$, visible transmittance range of $0.30-0.60,0.04$ emissivity coated, solar heat gain coefficient range of $0.12-0.47, U$-value of $1.45 \mathrm{~W} / \mathrm{m}^{2} \mathrm{~K}$ was investigated for Chicago (hot/cold climate) and Houston (hot climate) climate using EnergyPlus simulation. Result showed that critical switching temperature range between 14 and $20^{\circ} \mathrm{C}$, this thermochromic glazing offered 3.1-12.5\% less annual energy used in large commercial office building compared to IR selective low-e windows having visible transmittance of 0.64 , SHGC of 0.30 and $U$-value of $1.35 \mathrm{~W} / \mathrm{m}^{2} \mathrm{~K}$ [168].

Currently a dual intelligent thermocohromic glazing has been investigated. This glazing can modulate both solar and long wave radiation. Ye et al. [47] indicated that modulation of long-wave and solar radiations are equally important for energy efficient glazings. For traditional $\mathrm{VO}_{2}$ based thermochromic glazing has $\mathrm{VO}_{2}$ films that are located on the external surface of the glazing and internal surface remain with traditional silica based constant emissivity glass. Thus, emissivity of the external side is changeable. During hot daytime, external surface low emissivity reduces radiative heat gain. However, higher glazing temperature due to higher incident, absorbed solar radiation and equal emissivity between internal surface and glass allow heat to dissipate into the indoor space. In a dual intelligent thermochromic glazing $\mathrm{VO}_{2}$ film located on the internal surface [169]. For sunny summer day, the surface temperature of $\mathrm{VO}_{2}$ glazing becomes high which allows low solar transmittance. At this time long wave emissivity of internal surface of $\mathrm{VO}_{2}$ glazing is also low which restricts radiative heat transfer from glazing to building interior. For cloudy day $\mathrm{VO}_{2}$ glazed surface temperature is low and allow high solar and visible transmittance. At night absence of solar radiation heat dissipates from interior surface to cold sky by long wave thermal radiation [169]. Theoretically using reliable tool [154,155], dual intelligent glazing and traditional $\mathrm{VO}_{2}$ glazing system energy saving potential were investigated for a south facing $5 \mathrm{~m} \times 3 \mathrm{~m} \times 3 \mathrm{~m}$ office room in Guangzhou, China. It was found that dual intelligent glazing save $15.5 \%$ energy compared to traditional glazing to maintain $26^{\circ} \mathrm{C}$ indoor space temperature [169]. Daylight modulation using thermochromic glazing is not possible as visible transmission of thromochromic glazing varies between 38 and $40 \%$ that is low for glazing application. Solar energy modulation is only possible below 10\% [170]. Table 5 shows thermal and optical parameters for different investigated thermochromic glazing.

\subsection{Thermotropic}

Thermotropic materials are hydrogels, polymer blends, lyotropic and phase change material [171]. Hydrogel type thermotropic is aqueous polymer gel, which has a long chain of second polymer. Hydrogel thermotropic glazing was reported for large area application where the matrix material was water with watersoluble polymer hydrophobic groups, sodium chloride, and an amphipathettic molecule [172]. A hydrogel type thermotropic glazing is shown in Fig. 18. Polymer blends thermotropic contains polystyrene-co-HEMA and polypropylene oxide. At low temperature, two layers of polymer blends material have different refractive indices mix to each other. These two polymers are separated until heated sufficiently to reach a switching temperature [173]. Thermotropic liquid crystals, change colour from "transparent" to "opaque/translucent" state. At low temperature thermotropic materials are "transparent" while above switching temperature it becomes opaque/translucent as both transmitted and reflected lights are scattered. Below switching temperature, the two main transparent components are homogeneously mixed as refractive indices of the particles and matrix are equal the layer appears transparent. Above the threshold switching temperature, the particles change to phase with unequal refractive indices; radiation is scattered by the particles and the material reflects a portion of the incident solar radiation and the layer becomes "opaque". The switching temperature of the thermotropic material should be slightly less than the relative thermal index of the absorber material [174]. No visual contact with the external environment above the transition temperature makes its suitable for incorporation as high level glazing, as skylights or as roof lights [175]. Spectral behaviour of thermotropic glazing is shown in Fig. 19.

Thermotropic material prepared by hydroxypropyl methyl cellulose (HPMC), sodium chloride $(\mathrm{NaCl})$ and pure water in ratio of 2:10:100 had transmission of $72 \%$ and $32 \%$ in transparent and opaque states respectively. A west facing installation of this

Table 5

Literature data for thermochromic glazings.

\begin{tabular}{|c|c|c|c|c|c|c|}
\hline Dimension $(\mathrm{m} \times \mathrm{m})$ & Type of glazing & state & $U$-value $\left(\mathrm{W} / \mathrm{m}^{2} \mathrm{~K}\right)$ & SHGC & Visible transmission & Reference \\
\hline \multirow[t]{2}{*}{$1.65 \mathrm{~m} \times 1.65 \mathrm{~m}$} & $\mathrm{VO}_{2}$ single glazing & insulator & 5.8 & 0.58 & $43 \%$ & [166] \\
\hline & & Metallic & 5.8 & 0.53 & $42 \%$ & \\
\hline \multirow[t]{2}{*}{$1.65 \mathrm{~m} \times 1.65 \mathrm{~m}$} & $\mathrm{VO}_{2}$ double glazing & insulator & 3 & 0.47 & $38 \%$ & \\
\hline & & Metallic & 3 & 0.41 & $36 \%$ & \\
\hline
\end{tabular}



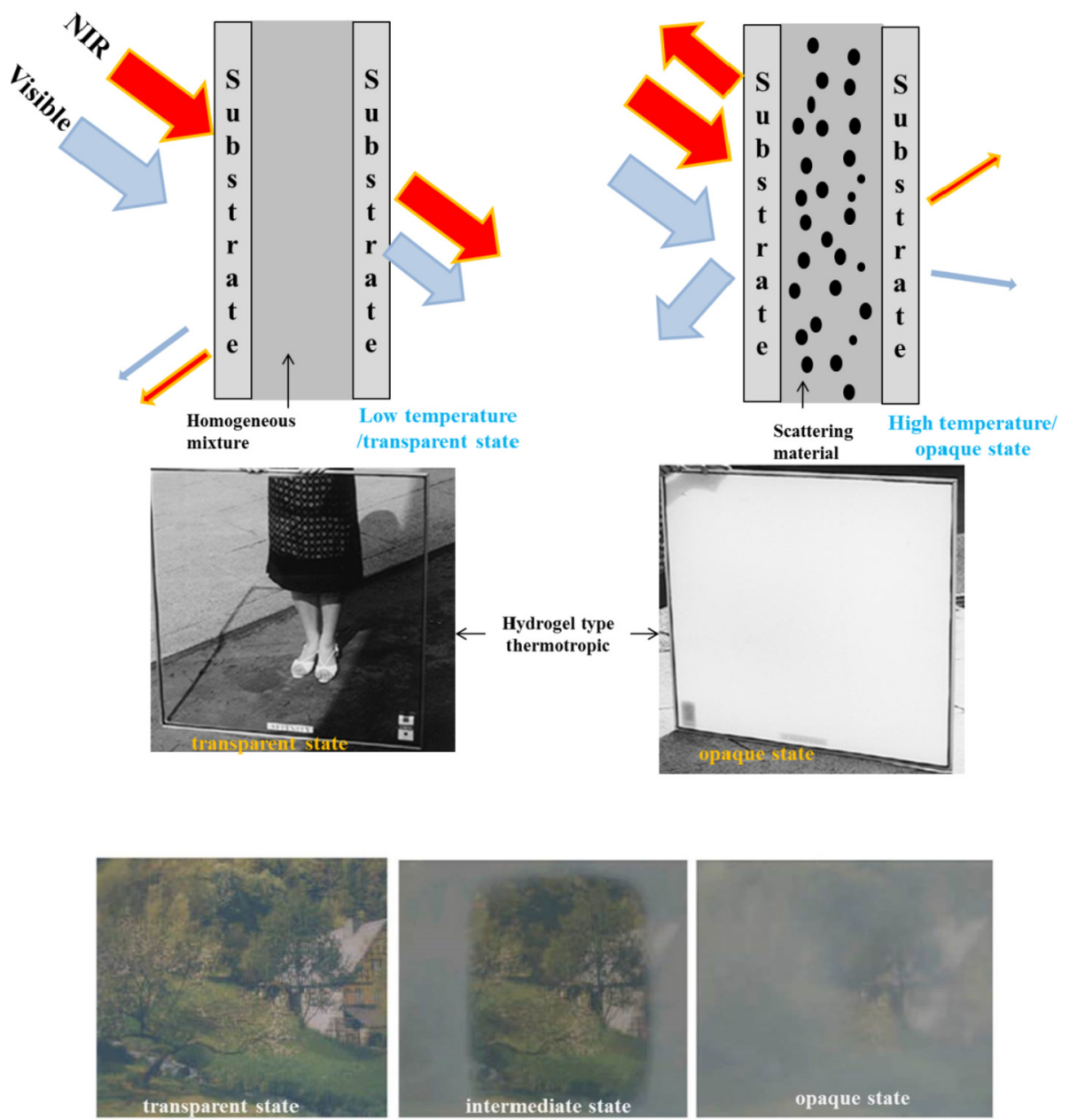

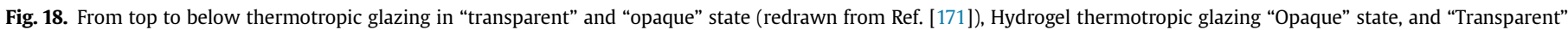
state [172], Switching of a thermotropic glazing laminate Okalux GmbH, Germany Nitz 2005 Reprinted from Ref. [171], with permission from Elsevier.

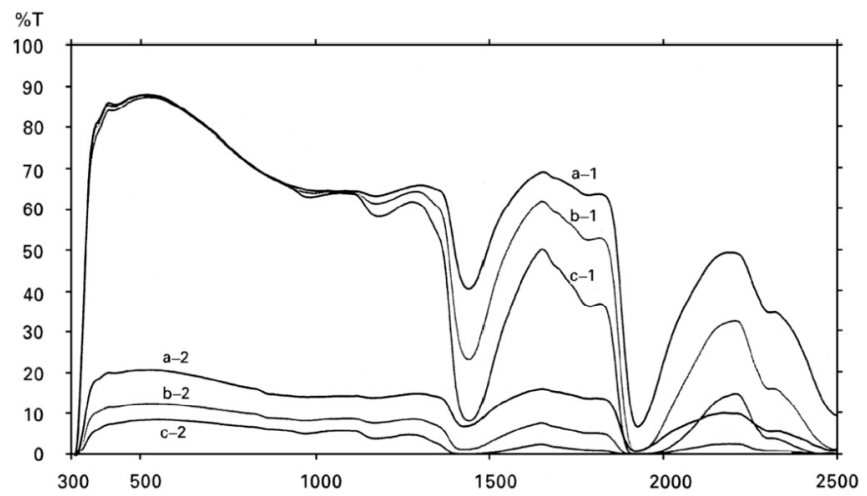

Fig. 19. Spectral transmission of a thermochromic glazing filled with (a) $0.25 \mathrm{~mm}$, (b) $0.5 \mathrm{~mm}$, and (c) $1.0 \mathrm{~mm}$ substrates. Reprinted from Ref. [172] with permission from Elsevier.

thermotropic glazing allowed $14.5 \%$ comfort level compared to double glazing and $2.4 \%$ compared to tinted double glazing in summer and winter in Hangzhou, China [176]. Double-glazing filled with thermotropic material can reduce 19\% cooling load and 3.6\% whole building energy consumption compared to an air filled double glazing [176]. A thermotropic single laminated glass and a triple glazed unit had switching phase interval between $28^{\circ} \mathrm{C}$ and
$34{ }^{\circ} \mathrm{C}$ that reduced the solar and visual transmittance between the transparent and the opaque state by around 20\% [177]. Switching behaviour of thermotropic material solely depends on temperature. High solar intensity low switching temperature will not heat up thermotropic material to change its phase [178]. Hybrid thermotropic hydrogels and electron-conducting indium-tin oxide using Joule heating can generate heat [179]. Table 6 shows thermal and optical parameters for investigated thermotropic glazing.

\subsection{Phase change material}

Phase change materials (PCM) are opaque when solid but become transparent while melted as shown in Fig. 20. As solar heat gain provides the latent heat for melting, the rate of solar heat gain through a PCM window is reduced at transition to become transparent [180]. It has potential to store considerable amounts of energy during their phase transition [180-184]. PCM slows the heat flow by absorbing some of the heat gain. PCM glazing is made by sandwiching the PCM material between two glass panes. At night, it releases store heat to become solid. PCM glazing is advantageous for winter evening as it can improve the thermal quality [185].

Working principle of PCM material is shown in Fig. 21. Fig. 21 (b) shows that PCM has ability to shift the peak energy demand from midday to afternoon period compared to sensible heat storage medium such as water, air or any other sensible storage medium which increase their temperature by absorbing heat and decrease 
Table 6

Literature data for thermotropic glazings.

\begin{tabular}{|c|c|c|c|c|c|c|}
\hline Dimension $(\mathrm{m} \times \mathrm{m})$ & Type of glazing & States & $U$-value $\left(\mathrm{W} / \mathrm{m}^{2} \mathrm{~K}\right)$ & SHGC & Visible transmission & Reference \\
\hline NA & Thermotropic double glazing & $\begin{array}{l}\text { Transparent } \\
\text { Opaque }\end{array}$ & 3.2 & $\begin{array}{l}0.66 \\
0.03\end{array}$ & & [176] \\
\hline
\end{tabular}

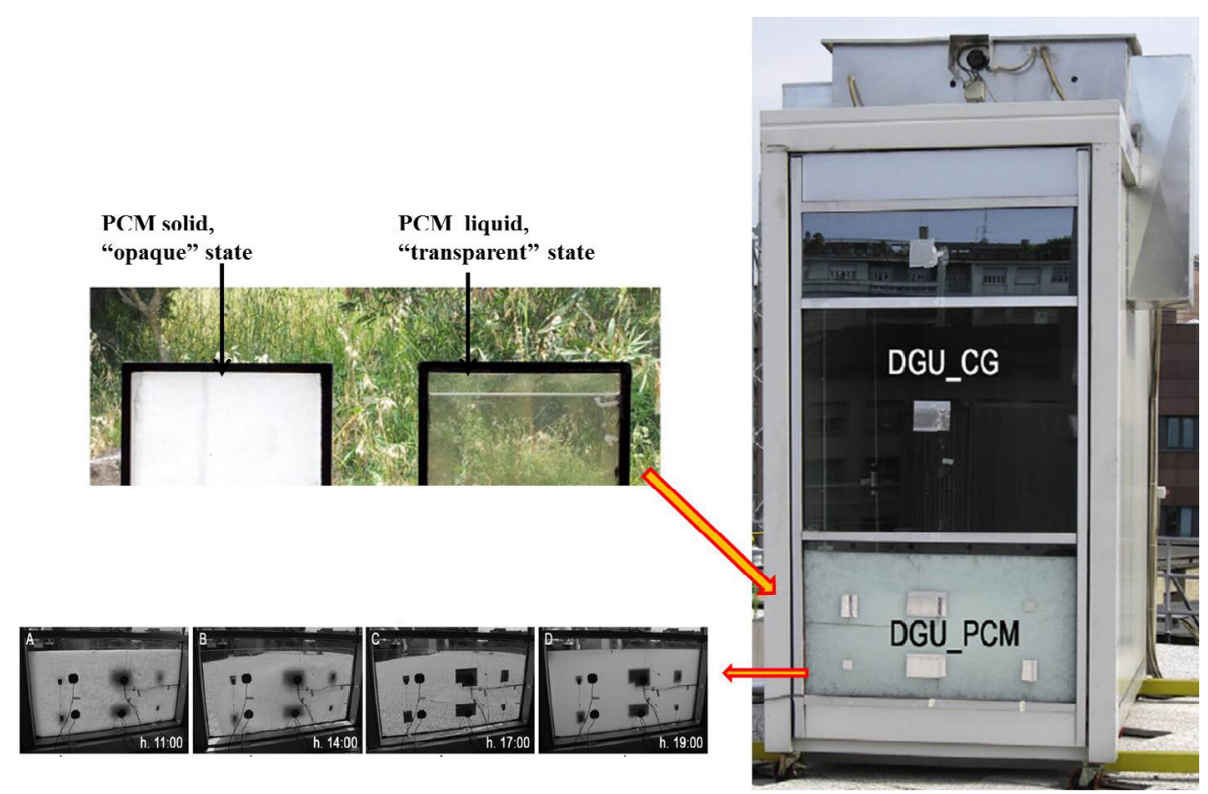

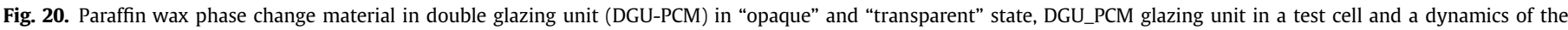
melting and re-solidification process of the paraffin layer within DGU-PCM during a sunny summer day. Reprinted from Refs. [186-188] with permission from Elsevier.

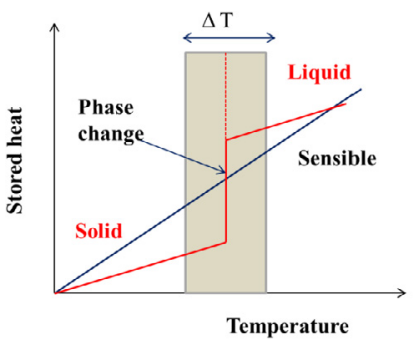

(a)

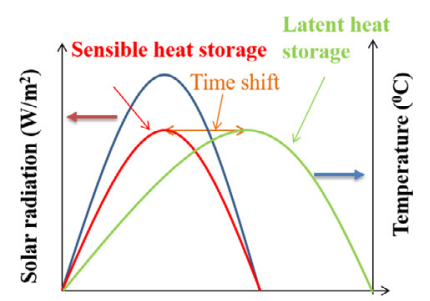

Time (h)

(b)
Fig. 21. (a) Phase chance of PCM and sensible heat storage (temperature of the sensible heat storage material rise when energy is absorbed and drops when energy is withdrawn). (b) Change of peak temperature using PCM.

the temperature by releasing the heat.

PCMs can be organic or inorganic or eutectic type. Optical properties of paraffin type of PCM for semi-transparent type application have been evaluated with a nominal melting temperature in the range $28-30{ }^{\circ} \mathrm{C}$ and a latent heat of fusion of about $230 \mathrm{~J} / \mathrm{g}$ [189]. Intensive experiment and simulation work was also performed by Goia et al. [187,188,190] using paraffin type PCM material for glazing application as shown in Fig. 20. Spectral transmission of this PCM filled double glazing is shown in Fig. 22.

Large $1.00 \mathrm{~m}^{2}$ PCM glazing was developed by using $13 \mathrm{~kg}$ paraffin wax PCM to fill the $15 \mathrm{~mm}$ cavity between two glass panes. Nominal melting temperature was $35^{\circ} \mathrm{C}$ and the heat storage capacity (in the $26^{\circ} \mathrm{C}-41^{\circ} \mathrm{C}$ temperature range) was $170 \mathrm{~J} / \mathrm{g}$ [186] of this PCM [188]. The large area of the glazing avoided edge effects of the aluminium frame. Specular and angular behaviour of paraffin based different thickness of PCM glazing showed that thickness of
PCM layer had weak effect on reflection of PCM however had high impact on the transmission and absorption coefficient. It was found that reflectivity of PCM in solid state was up to three times higher than PCM in liquid state. Absorption coefficient of solid PCM was also higher than its liquid state [191,192]. Commercially available salt hydrate $\mathrm{PCM}, \mathrm{CaCl}_{2} \cdot 6 \mathrm{H}_{2} \mathrm{O}$ with latent heat of fusion of approximately $190 \mathrm{~kJ} / \mathrm{kg}$, a nominal melting temperature of approximately $27^{\circ} \mathrm{C}$ and small super cooling effects $\left(1-3^{\circ} \mathrm{C}\right)$ [193] was experimentally investigated using outdoor test cell. Transmission of this glazing was $1 \%$ and $80 \%$ when opaque and transparent respectively. Double glazing filled PCM showed 30\% less heat losses compared to a double glazing without PCM, in south oriented facades. Solar heat gains are also reduced by about $50 \%$ [185]. Numerical investigation on PCM filled double glazing showed that this glazing had solar heat gain coefficient in the range of $0.65-0.8$ under $600 \mathrm{~W} / \mathrm{m}^{2}$ incident solar radiation and $24^{\circ} \mathrm{C}$ internal ambient temperature while outside was $35^{\circ} \mathrm{C}$. In this work, detail of thermo-optical parameters of PCM were not explained [184]. In hot summer and cold winter area of China, inorganic PCM glauber salt $\left(\mathrm{Na}_{2} \mathrm{SO}_{4} \cdot 10 \mathrm{H}_{2} \mathrm{O}\right)$ filled PCM double-glazing was able to restrict $39.5 \%$ entering heat compared to air filled double-glazing. PCM filled glazing had transmittance of 0.76 and absorptance of 0.19 [194]. No experiment work using PCM glazing for daylighting and glare control has been conducted. Thermal and chemical stability of paraffin based PCM glazing was investigated by Ref. [195]. It was found that latent heat of aged paraffin PCM reduced to 5\% compared to pristine one. Melting temperature decreased about $2{ }^{\circ} \mathrm{C}$ for cooling mode and $1.5^{\circ} \mathrm{C}$ for heating mode after one year of operation. As PCM become transparent mostly during midday period it is unsuitable for glare control. This mismatch behaviour limits application. PCM in solid phase increase the window weight 


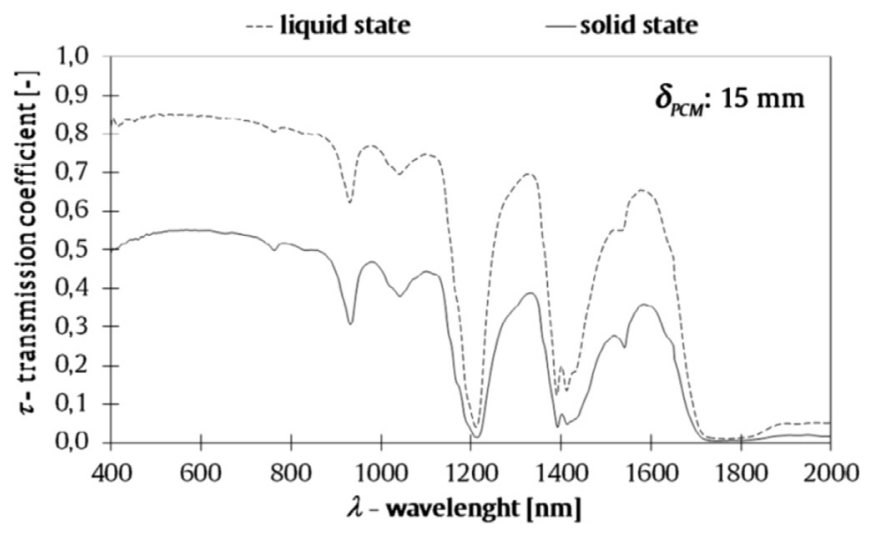

Fig. 22. Spectral transmission of a PCM double glazing filled with $15 \mathrm{~mm}$ thick paraffin type PCM layer in solid and liquid state. Reprinted from Ref. [191] with permission from Elsevier.

and the change of volume between the two states $(\sim 10 \%)$ are the major drawbacks of this type of glazing. Table 7 shows thermal and optical parameters for investigated PCM glazing.

\subsection{Gasochromic}

A gasochromic film is composed of tungsten trioxide $\left(\mathrm{WO}_{3}\right)$ layer with a very thin coating of a platinum $(\mathrm{Pt})$ or palladium $(\mathrm{Pd})$ type catalyst. This film becomes opaque or bluish colour when expose to a low concentration hydrogen. It becomes transparent on exposure to oxygen [196-198]. Gasochromic material sandwiched between double-glazing as shown in Fig. 23 has potential to offer up to $75 \%$ solar transmittance when transparent. In the opaque state, the gasochromic material absorbs solar radiation to produce heat is conveyed to the ambient by convection. Spectral transmission of gasochromic glazing is shown in Fig. 24.

Properties of a gasochromic glazing depend on the crystal configuration (i) water content inside it, (ii) chemical composition and (iii) microscopic structure. Controllable gasochromic properties are available in monocrystalline, polycrystalline, and amorphous films where amorphous type shows better gasochromic properties compared to others [200]. Gasochromic $\mathrm{WO}_{3}$ film can be manufactured by electron beam evaporation [196,201], sputtering [202-204], sol-gel, electrodeposition [205,206]. For large scale $\mathrm{WO}_{3}$ film manufacturing, low cost sol-gel methods are promising due to simple equipment requirement. Without heat treatment in sol-gel process develops easily stretchable and low stability $\mathrm{WO}_{3}$ films [205,207,208]. Presence of $\mathrm{WO}_{3}$ layer in gasochromic glazing makes it comparable with EC glazing though gasochromic glazing has structural difference with EC glazing. To obtain EC glazing 5 layers are required (ITO-ion storage-ion conducting-EC-ITO) where as gasochromic glazing is possible with only $\mathrm{WO}_{3}$ layer with palladium (Pd)-catalyst. $\mathrm{WO}_{3} / \mathrm{Pd}$ layer can be coated on any transparent substrate; however, for EC glazing usage of transparent conductor is limited [207,209-212]. Platinum (Pt) coated, porous, less than $1 \mu \mathrm{m}$ thick columnar film of $\mathrm{WO}_{3}$ was prepared for a gasochromic glazing which offered a very fast less than $10 \mathrm{~s}$

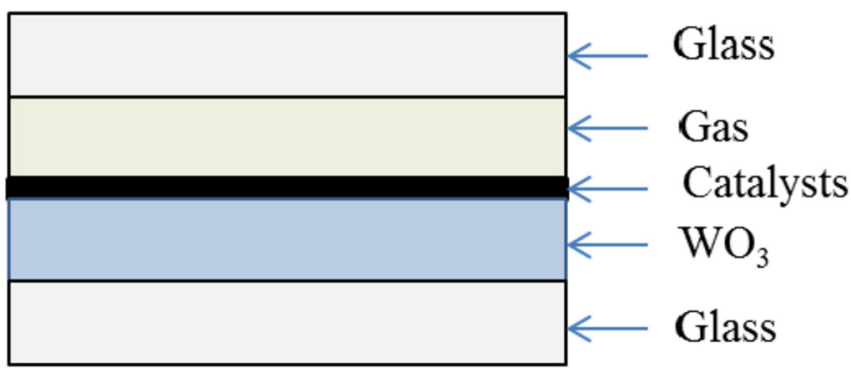

Fig. 23. Structure of a gasochromic glazing.

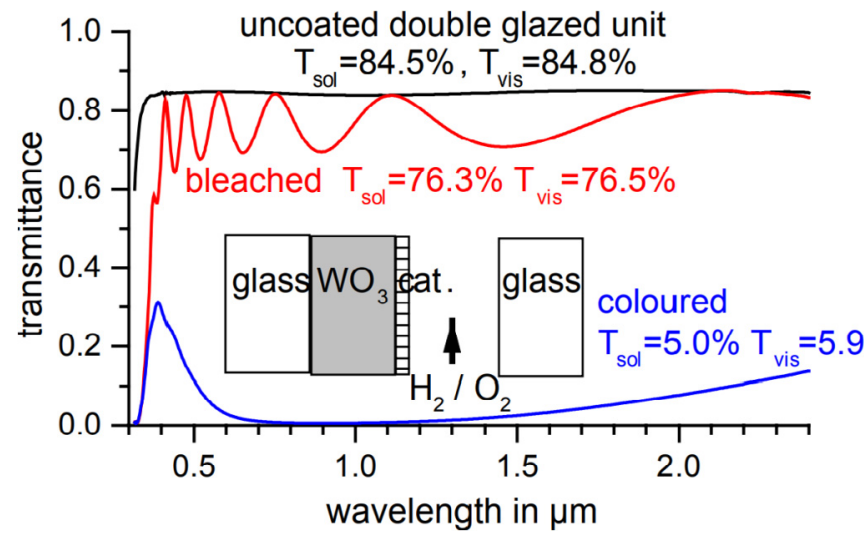

Fig. 24. Spectral transmission of gasochromic double-glazing. Reprinted from Ref. [199] with permission from Elsevier.

switching speed [213]. The switching process of this glazing takes less than $10 \mathrm{~s}$. A homogeneous colouration process was achieved within a second [214]. A $1.1 \times 1.6 \mathrm{~m}^{2}$ glazing offered 20,000 times switching for 2 years without any significant performance degradation. First few days of operation showed instantaneous transparent and bleaching transformation. After 2 years of operation, glazing transmission change from $60 \%$ to $24 \%$ took $1 \mathrm{~min}$ while remaining $10 \%$ changed in $10 \mathrm{~min}$. To become transparent this glazing took $1 \mathrm{~min}$ to achieve 50\% transparent while fully transparent became after $3 \mathrm{~min}$ [196]. A $0.8 \times 1.2 \mathrm{~m}^{2}$ gasochromic switchable mirror, manufactured by magnetic sputtering machine [215] from Mg-Ni alloy and Pd films, switched from the mirror state to the transparent state by introducing $4 \% \mathrm{H}_{2}$ in $\mathrm{Ar}$ within $15 \mathrm{~s}$, while the reverse change took about 8 min by introducing $4 \% \mathrm{O}_{2}$ in Ar. The mirror state was able to reduce energy consumption by $34 \%$ compared to a transparent double-glazing window [215]. Annual consumption for use of GC DGU in an eight-storey commercial office building dimension of $45 \mathrm{~m} \times 15.24 \mathrm{~m} \times 3 \mathrm{~m}$ in Shanghai city was evaluated using eQUEST 3.64 program. This glazing reduced the annual consumption of HVAC loads by $25-35 \%$ compared to single clear float glass [212].

Gasochromic window may present hydrogen explosion. Continuous monitoring is essential for hydrogen leakage at operation site or for storage [216]. The low concentration of hydrogen

Table 7

Literature data for PCM glazings.

\begin{tabular}{|c|c|c|c|c|c|c|}
\hline Dimension $(\mathrm{m} \times \mathrm{m})$ & Type of glazing & States & $U$-value $\left(\mathrm{W} / \mathrm{m}^{2} \mathrm{~K}\right)$ & SHGC & Visible transmission & Reference \\
\hline NA & $\begin{array}{l}\text { PCM glazing } \\
\text { ( } 3 \text { mm thick PCM) }\end{array}$ & Transparent & 4.69 & 0.683 & & [183] \\
\hline & & Opaque & & & & \\
\hline
\end{tabular}


used for switching process could limit the risk of the explosion. For large area application, gasochromic is more suitable as the coating structure is single layer, which is much simpler than double layer structure. Cost of this glazing can be reduced as here no need for transparent conducting oxide (TCO) layer and single chromic layer structure [199]. Table 8 shows thermal and optical parameters for investigated gasochromic glazing.

Table 9 summarised the comparative properties of nonelectrically activated glazing systems.

\section{Electrically actuated switchable material}

This section outline the present research status of the electrically actuated switchable glazing in the laboratory level with industrial collaboration or commercial product. Currently three electrically activated glazings are well known, elecrochromic (EC), suspended particle device (SPD) and liquid crystal (LC). Electrically activated switchable glazing offers user control, which is advantageous over non-electrically control.

\subsection{Electrochromic}

Electrically actuated electrochromic (EC) glazing is made by EC material sandwiched between two glass panes [218,219]. EC [220] includes (i) transition metal oxides like tungsten, iridium, rhodium, ruthenium, manganese and cobalt possesses [220,221] (ii) organic material such as prussian blue, viologens, buckminsterfullerene, polypyrrole, polyaniline (PANI), Poly (3,4-ethylene-dioxythiophene) (PEDOT) [222-224].

Mechanical flexibility, multicolour adjustability, low cost easy fabrication process, short coloring and bleaching switching times, high optical contrast, and high colouration efficiency makes organic polymer EC material [225,226] a future potential for EC glazing application. However, low thermal stability of polymers is the hindrance for organic EC glazing applications [226]. Research activities are engaged to improve the stability of organic EC for glazing application. One polymer based EC glazing showed 50,000 times [227] and one viologen based EC glazing offered 2 years [228] durability. Further investigation is required for organic EC material to compete with inorganic, as they possess higher stability.

Inorganic materials have better lifetime and UV stability than organic materials. Among all the materials, tungsten tri oxide $\left(\mathrm{WO}_{3}\right)$ material is attractive for EC glazing [229,230]. $\mathrm{WO}_{3}$ crystals structures are similar to perovskite-type, and birefringent by nature with 2.5 average refractive index [231,232]. The EC behaviour of $\mathrm{WO}_{3}$ due to application of electric voltage was first observed by Deb in 1969, previously electrochromism was only associated with organic materials. EC material for glazing was proposed by Ref. [221]. In a typical EC glazing as shown in Fig. 25 an EC layer, ion storage layer, and ion conducting layer are sandwiched between

Table 8

Literature data for gasochromic glazings.

\begin{tabular}{|c|c|c|c|c|c|c|}
\hline Dimension $(\mathrm{m} \times \mathrm{m})$ & Type of glazing & States & $U$-value $\left(\mathrm{W} / \mathrm{m}^{2} \mathrm{~K}\right)$ & SHGC & Visible transmission & Reference \\
\hline & & Transparent & 2.612 & 0.65 & 0.54 & [212] \\
\hline & & Opaque & & 0.28 & 0.15 & \\
\hline
\end{tabular}

Table 9

Comparison of non-electrically activated switchable glazing systems.

\begin{tabular}{|c|c|c|c|c|}
\hline Property & Thermochromic & Thermotropic & Phase change material & Gasochromic \\
\hline Transparent state & $\begin{array}{l}\text { Below the transition } \\
\text { temperature }\end{array}$ & $\begin{array}{l}\text { Below the transition } \\
\text { temperature }\end{array}$ & Above the transition temperature & Addition of oxygen \\
\hline Opaque state & Above transition temperature & Above transition temperature & Below the transition temperature & Addition of hydrogen \\
\hline Memory & $\begin{array}{l}\text { Transparent and opaque both } \\
\text { state remain for hours } \\
\text { depending on ambient } \\
\text { /transition } \\
\text { temperature and area of device. }\end{array}$ & $\begin{array}{l}\text { Transparent and opaque both state } \\
\text { remain for hours depending on } \\
\text { ambient } \\
\text { /transition } \\
\text { temperature and area of device. }\end{array}$ & $\begin{array}{l}\text { Transparent state remains for few } \\
\text { hours depends on ambient } \\
\text { temperature and heat release } \\
\text { capacity of PCM }\end{array}$ & $1 \mathrm{~min}$ \\
\hline Durability & $\begin{array}{l}300^{\circ} \mathrm{C} \text { for dry air and } 80^{\circ} \mathrm{C} \text { for } \\
95 \% \text { relative humidity, bare } \\
\text { thermochromic } \mathrm{VO}_{2} \text { film } \\
\text { degrades } \\
\text { [217] }\end{array}$ & $\begin{array}{l}200 \text { cycle operating between } 20^{\circ}- \\
80^{\circ} \mathrm{C} \\
{[172]}\end{array}$ & $\begin{array}{l}\text { Solar radiation has less impact } \\
\text { Due to thermal cycle melting } \\
\text { temperature decreased to } 2^{\circ} \mathrm{C} \text { after } \\
\text { one year. } \\
\text { [195] }\end{array}$ & $\begin{array}{l}\text { 10,000-20000 cycles } \\
{[196]}\end{array}$ \\
\hline $\begin{array}{l}\text { Near Infra-Red } \\
\text { (NIR) control }\end{array}$ & $\begin{array}{l}\text { Reflect NIR, } \\
\text { Modulate NIR and IR }\end{array}$ & Reflect NIR & Absorb NIR for both states & $\begin{array}{l}\text { Low NIR transmission in } \\
\text { opaque state, } \\
\text { Modulate NIR }\end{array}$ \\
\hline Switching time & $\begin{array}{l}\text { Vary with transition } \\
\text { temperature and area of device }\end{array}$ & $\begin{array}{l}\text { Vary with transition temperature } \\
\text { and area of device }\end{array}$ & $\begin{array}{l}\text { Vary with transition temperature } \\
\text { and area of device }\end{array}$ & Less than $10 \mathrm{~s}$ \\
\hline $\begin{array}{l}\text { Intermediate } \\
\text { states }\end{array}$ & $\begin{array}{l}\text { Uncontrolled intermediate } \\
\text { states }\end{array}$ & Uncontrolled intermediate states & $\begin{array}{l}\text { Uncontrolled inhomogeneous } \\
\text { intermediate states }\end{array}$ & $\begin{array}{l}\text { Using different hydrogen and } \\
\text { oxygen concentration, } \\
\text { intermediate states are possible }\end{array}$ \\
\hline$U$-value & Similar to single glazing & Close to double glazing. & $\begin{array}{l}\text { Similar to single glazing (Double } \\
\text { panes filled with PCM) }\end{array}$ & Close to double glazing. \\
\hline SHGC & $\begin{array}{l}\text { Modulation of SHGC is low due } \\
\text { to low modulation of solar } \\
\text { transmission. } \\
\text { IR modulation is high }\end{array}$ & Modulation of SHGC is high & Controls & Modulation of SHGC is high \\
\hline Daylight/glare & $\begin{array}{l}\text { No daylight modulation as it } \\
\text { offers similar visible } \\
\text { transmission for both states. }\end{array}$ & $\begin{array}{l}\text { Opaque and transparent both state } \\
\text { can control daylight and glare. } \\
\text { Opaque occurs during midday (high } \\
\text { temperature) and transparent } \\
\text { occurs during morning and } \\
\text { afternoon (low temperature). }\end{array}$ & $\begin{array}{l}\text { Inhomogeneous melting and } \\
\text { solidification process may be } \\
\text { unacceptable for users. } \\
\text { Transition and opaque/translucent } \\
\text { state can control daylight/glare. }\end{array}$ & $\begin{array}{l}\text { High modulation of luminous/ } \\
\text { visible transmission thus } \\
\text { control over daylight is high } \\
\text { and potential for glare control. }\end{array}$ \\
\hline
\end{tabular}



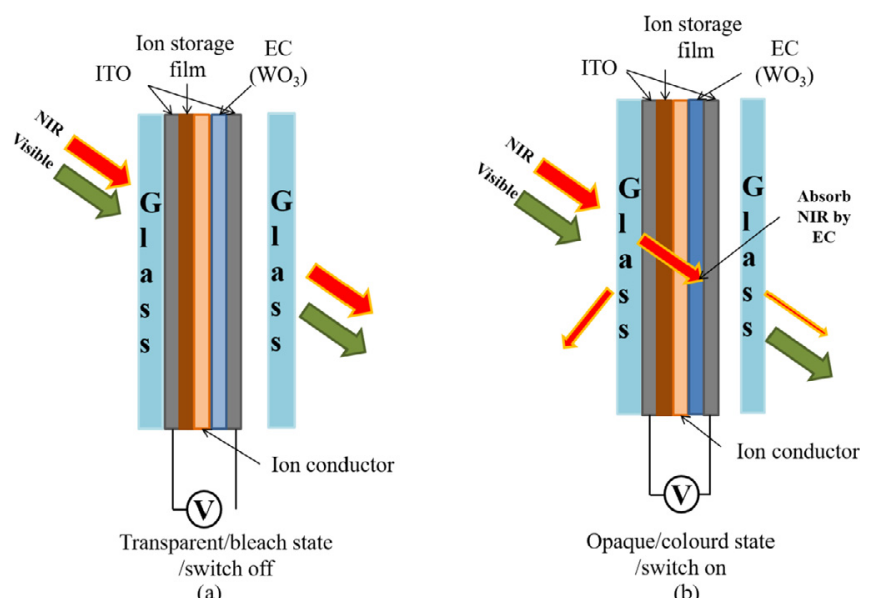

(a)

(b)

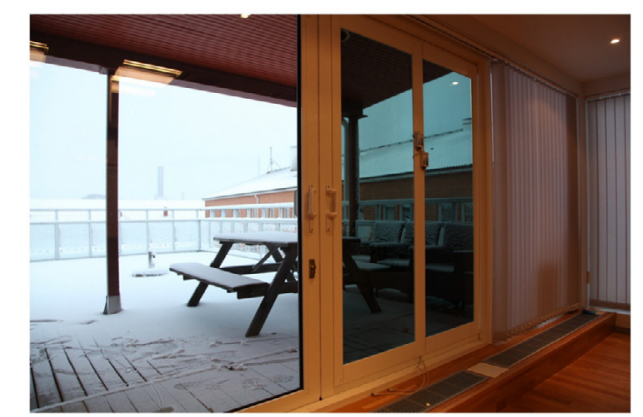

(c)

Fig. 25. Schematic diagram of electrochromic glazing in its (a) "bleached" (b) "coloured" state (c) photograph of web coated EC glazing in its bleached and colours state in an office building (Taken from Ref. [260] with permission of Elsevier.).

two transparent conducting oxides [233-235].

Indium tin oxide is the most commonly used transparent electrical conductors. Used ion storage layer may or may not have EC properties. A transparent ion conductor (electrolyte) joins the EC and ion storage films. Electrolyte can be transparent liquid [236] or polymer type [237]. Presently, four different types of EC glazing systems have been manufactured by different research groups and commercial companies. Five layer monolithic device backed by single glass substrate was designed by SAGE glass electrochromic $[238,239]$. Flabeg/EControl Glass GmbH in Germany produced two parallel double-layer-coated glass substrates joined by a polymer electrolyte [240]. Cathodically coloring material $\mathrm{WO}_{3}$ and anodically coloring Prussian Blue, Polyvinyl butyral (PVB) electrolyte based laminated EC device was successfully developed by Gesimat [241-243]. Polymer-foil-based laminated design [219,244] and low-cost technology developed by ChromoGenics AB spin off founded by Prof C.G. Granqvist and his team at Angstrom Laboratory of Uppsala University in Sweden. To achieve flexible EC, deposition was performed on a polyester [245,246].

The primary purpose of EC glazing is to control the solar heat gain [244] [247-250]. An EC material change from "transparent/ bleach" to "coloured" by redox reaction when D.C. voltage between 0 and $5 \mathrm{~V}$ is applied [251] and is reversible by inversion of electrical supply [252,253]. Colouration and bleaching time of EC device depends on the active area of the device. EC also shows "iris" effect, which shows faster colour change at the edge while centre has slower compared to edge. This can be mitigated by using suitable powering [254]. EC glazing switching below and above design temperature is not permitted as higher operating power decrease the durability of EC glazing while lower operating voltage cannot switch the glazing $[255,256]$. Switching below $0{ }^{\circ} \mathrm{C}$ may cause device degradation due to ice in $\mathrm{WO}_{3}$ pores [257]. EC material is potential glazing candidate as it can control transmission, absorption, reflection, and emission of a glazing [244]. EC device can be resembled as battery like in structure $[258,259]$.

At "coloured" state crystalline type $\mathrm{WO}_{3}$ blocks the near infrared (NIR) or reflects it [261]. Controlling NIR an EC glazing can provide heating and cooling energy savings range from 5 to $15 \mathrm{kWh} / \mathrm{m}^{2} \mathrm{yr}$ for commercial and residential building, in comparison with high performance static glazing [262]. Solar heat gain values were found to be 0.39 to 0.05 of an EC material having $63 \%$ transparent state and $1.2 \%$ transparent state respectively [263]. Energetic performances of an EC window was performed using PASSYS cell test with an array of 64 pieces of $12 \mathrm{~cm} \times 12 \mathrm{~cm}$ EC elements. This glazing had $3.8 \mathrm{~W} / \mathrm{m}^{2} \mathrm{~K}$ overall heat transfer coefficient. For $4 \%$ transparent coloured state it had 0.16 SHGC and $60 \%$ transparent bleached state had 0.7 SHGC [264]. An EC system using tungsten oxide and vanadium pentoxide showed solar transmittance modulation between $58 \%$ and $9 \%$ and visible transmittance modulation between $65 \%$ and $13 \%$ in the "bleaching" and "coloured" states respectively [265]. Another work reported $72.6 \%$ transparency during "bleaching" state and $17.6 \%$ during "coloured" state of an EC glazing [235]. $45 \%$ energy saving was found using an EC glazing for an office building in hot climate area Arizona or very cold climate area Minnesota [238]. In USA, a simulation study showed that $18 \%$ retrofit of the total window stock of building (medium offices and midrise residential buildings in northern climates) using near infrared switching electrochromic (NEC) could save 50\% energy and $39 \%$ retrofit could save $75 \%$ of buildings total energy (heating, cooling, ventilation and interior lighting) consumption [266].

EC glazing has also potential to introduce the daylighting control and reduce the lighting energy demand, reducing the use of shading device [267]. EC glazing can save 44-59\% daylighting energy compared to an unshaded glazing [268]. EC glazing system with a transmittance range of $0.08-0.88$ maintained stable daylight illumination levels of 500 lux in an office space under overcast and sunny conditions for sunny Arizona climate [269]. A small-scale EC glazing prototype using test cell has been investigated under real weather condition, which was able to reduce discomfort glare caused by EC glazing brightness from diffuse daylight. This result showed that switchable glazing is effective for glare comfort although it cannot be fully opaque when direct sunlight penetrates. It reduces the necessity of shading device, which does not obstruct any view to the outside [270-272].

Long-term durability and electrochemical cycling durability are the obvious criteria of EC device for glazing application. Recent development showed that rejuvenation of degraded EC films, both based on $\mathrm{W}$ oxide and $\mathrm{Ti}$ oxide are possible by galvanostatic treatment [273-275]. Large scale $1.2 \mathrm{~m} \times 0.8 \mathrm{mEC}$ glazing was experimentally tested using one $2.7 \mathrm{~m} \times 2.7 \mathrm{~m} \times 5 \mathrm{~m}$ south facing PASSYS test cell and for a west facing office room. Both results suggested that this EC device has potential to offer user comfort and energy savings [241]. NIR controlling potential of EC glazing also makes it superior compared to other electrically activated switchable glazing [228] as shown in Fig. 26.

It was also found that EC glazing needs low voltage than its rated required voltage at high glazing temperature [276]. At high temperature due to higher ion mobility switching responses are faster which reduce the amount of required voltage [277-282]. EC material switching response decreases exponentially at higher device temperature. In addition, use of liquid electrolyte can reduce switching responses than solid electrolyte due to higher ionic mobility. EC glazing has memory effect, which make this glazing to be in coloured state for long hours even after the supply is disconnected. Low operating power requirement also make it 


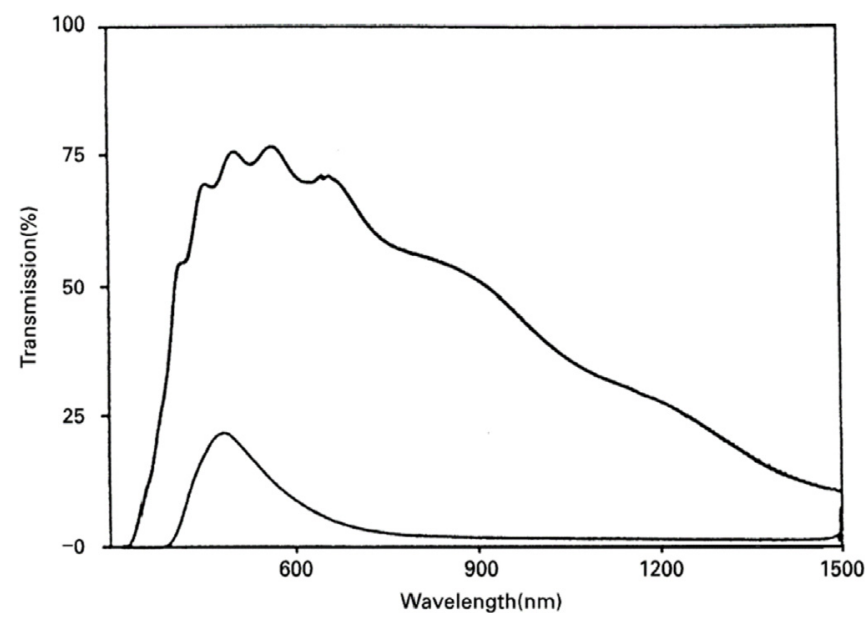

Fig. 26. Spectral transmittance for an Asahi EC window with $72 \%$ visible and $53 \%$ solar transmission at bleached state and $20 \%$ visible and $10 \%$ solar transmission while switching occurred at $2 \mathrm{~V}$ to -0.7 . (Taken from Ref. [224] with permission of Elsevier).

viable for building application [260]. Table 10 shows the literature data for thermal and optical performance of different investigated EC glazing.

\subsection{Suspended particle device (SPD)}

Suspended particle device (SPD) technology was first invented in 1930 and patented. SPD device works on same principle as of light valve where a cell is formed using two transparent sheets of insulating material spaced apart a small distance and containing a suspension of small particles in a liquid medium [284]. Particles can be dihydrocinchonidine bisulfite polyiodide or heraphathite. Shape of the particle can be needle-shaped, rod-shaped, or lath-shaped types. Presence of electrical field allows these liquid suspended particles to move randomly due to Brownian movement and absorbs light passing into the cell. Thus, light valve is dark in the opaque state or no power state. Percentage of light absorption depends on the cell structure, nature, and concentration of the particles and the energy content of the light. In the presence of an applied electrical field, particles become aligned and allow most of the light pass through the cell [285]. Thus, the light valve becomes transparent. This technology is known over seventy years for the application of modulation of light in the field of alphanumeric and television displays, and work as a filters for optical devices. For glazing applications, plastic films are preferred than a liquid suspension. Plastic film eliminates the possibility of bulging effect during high column of suspension due to hydrostatic pressure and leakage possibility from the device. In a plastic film, only small numbers of particles are available which do not noticeably agglomerate during repeatedly activation of the film using applied electric filed. SPD light valve uses a film made of cross-linked polymer matrix having refractive index of 1.4 and suspended

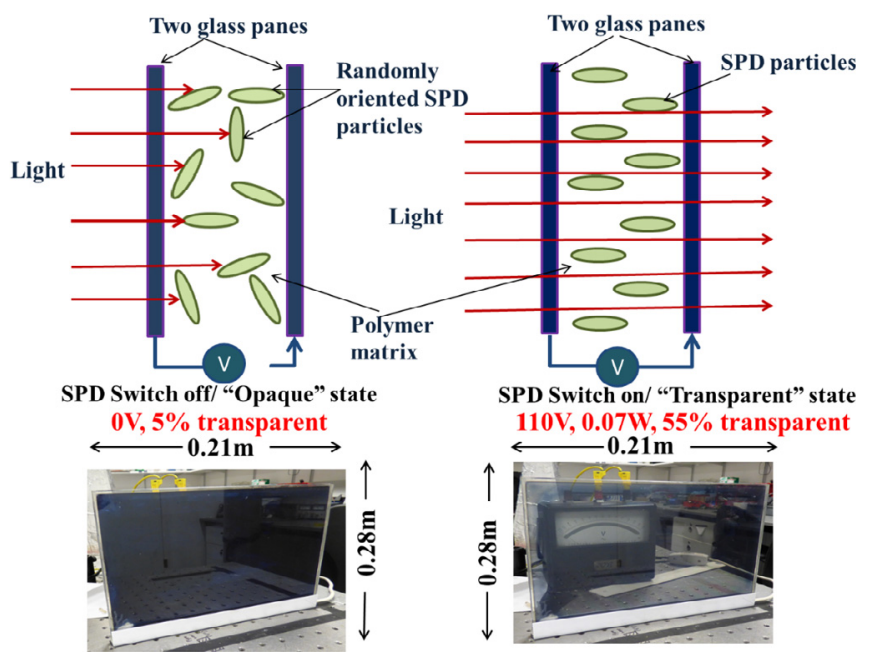

Fig. 27. Suspended particle device (SPD) glazing switching for (a) "opaque" and (b) "transparent" states. Reprinted from Ref. [287] with permission from Elsevier.

liquid light valve distributed in the matrix [285]. In shatterresistant laminated suspended particle device (SPD), SPD interlayer was laminated between two sheets of glass. Research Frontiers Inc (RFI) develops commercial SPD devices for goggles, eyeglasses, and windows.

Two groups Dublin energy lab, in Dublin and Grupo de Displays $\mathrm{y}$ Aplicaciones Fotonicas in Spain have investigated thermal, daylighting and optical properties of SPD glazing using outdoor and indoor characterisation. SPD glazing thermal [286], electrical [287] and daylighting [288] behaviour was investigated using outdoor test cell characterisation. This SPD glazing changed its state from $5 \%$ to $55 \%$ in the presence of $110 \mathrm{~V}, 0.07 \mathrm{~W}$ AC power [287,289] as shown in Figs. 27 and 28. It was also found that SPD glazing has intermediate transmittance state in the presence of variable applied power using indoor experiment. SPD glazing's high overall heat transfer $5.9 \mathrm{~W} / \mathrm{m}^{2} \mathrm{~K}$ makes it as a switchable single glazing [286]. However, it has potential to control the solar heat gain from 0.05 to 0.38 while it is opaque and transparent respectively [290]. Thus, SPD is a potential candidate for summer and in hot climates. However, SPD double-glazing can save $66 \%$ heat loss compared to an SPD single glazing, which is suitable for cold climatic area [286]. SPD vacuum glazing can be the best suitable option for cold climatic area as it can save up to $83 \%$ heat losses compared to SPD single glazing [76]. SPD glazing also offers comfortable daylight in to the indoor environment for the occupant satisfaction [291]. Intermediate state $30 \%$ is recommended for SPD glazing which can offer comfortable daylight.

Indoor spectrometer measurement [292] and electro optical [293] simulation were performed by Barrios et al. The electrooptical behaviour SPD glazing was also analyzed. Impedance analysis showed that SPD glazing characteristics are similar to a Randles circuit. SPD glazing takes higher voltage to obtain fully

Table 10

Literature data for electrochromic (EC) glazings.

\begin{tabular}{|c|c|c|c|c|c|c|}
\hline Dimension $(\mathrm{m} \times \mathrm{m})$ & Type of glazing & States & $U$-value $\left(\mathrm{W} / \mathrm{m}^{2} \mathrm{~K}\right)$ & SHGC & Visible transmission & Reference \\
\hline \multirow[t]{2}{*}{$0.105 \mathrm{~m} \times 0.105 \mathrm{~m}$} & \multirow[t]{2}{*}{ EC glazing } & Transparent & 3.9 & 0.7 & $65 \%$ & \multirow[t]{2}{*}{ [264] } \\
\hline & & Opaque & 3.9 & 0.17 & $4 \%$ & \\
\hline \multirow[t]{2}{*}{$0.21 \mathrm{~m} \times 0.28 \mathrm{~m}$} & \multirow[t]{2}{*}{ EC glazing } & Transparent & 1.59 & 0.41 & $60 \%$ & \multirow[t]{2}{*}{ [283] } \\
\hline & & Opaque & 1.59 & 0.09 & $1 \%$ & \\
\hline \multirow[t]{2}{*}{ NA } & EC PPG, Solarban 72 Starphire, & NIR blocking & 1.625 & 0.297 & $68 \%$ & \multirow[t]{2}{*}{ [262] } \\
\hline & PPG, Sungate 400 Starphire & NIR transmitting & 1.804 & 0.646 & $78 \%$ & \\
\hline
\end{tabular}




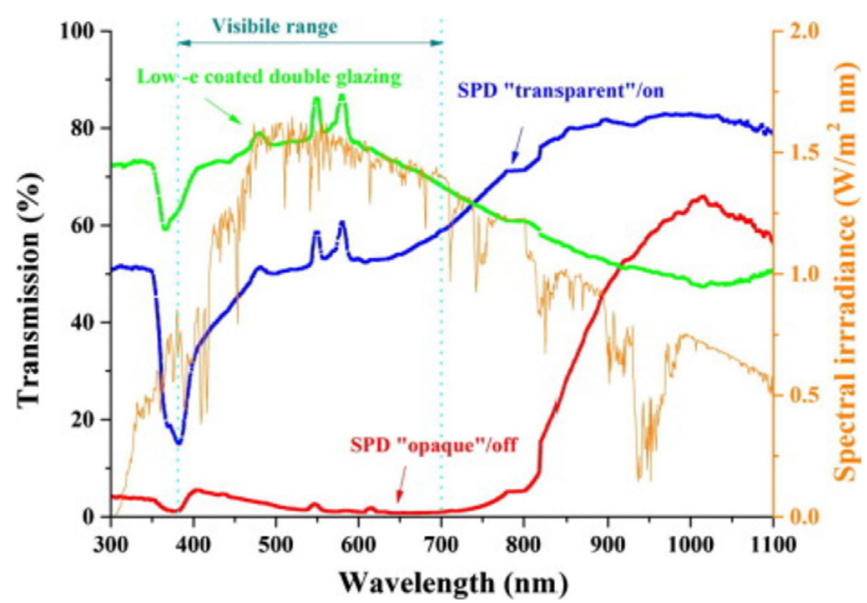

Fig. 28. Transmittance spectra of SPD glazing during on and off condition. Reprinted from Ref. [290] with permission from Elsevier.

transparent state, which can be reduced by decreasing the layer thickness of SPD layer. Thickness of SPD layer has ability to tune the luminous and solar transmittance. It was proposed that for adaptive glazing application SPD layer thickness between 200 and $300 \mu \mathrm{m}$ is the most suitable as it offers the highest luminous and solar transmittance contrast. SPD glazing has higher infrared transmission and variation of this transmission is negligible for variation of power [294]. Durability of SPD glazing was investigated after four years of exposure (where one year laboratory environment and three years Dublin outdoor environment) which showed that contrast ratio (opaque to transparent) changed only from 1:11 to $1: 10$. To conclude any strong statement about SPD glazing's stability further investigation is essential [284]. It was also found that SPD glazing voltage requirement does not depend on its surface temperature [284]. Table 11 shows the investigated thermal and transmission parameters for different SPD glazing.

\subsection{Liquid crystal}

Liquid crystal (LC) is an AC powered electrically activated switchable glazing which is suitable for building glazing application. In this glazing LC are sandwiched between two glass panes. Twisted nematic, ferroelectric, guest host, and polymer dispersed are the major liquid crystal used for LC device [295].

Smectic A liquid crystal (SmA LC) and PDLC are the two form of LC which do not require polarisers to operate. PDLC needs 1-10 ms whereas SmA needs few ms to switch on. Scattering process of SmA LC devices start from the edges or conductive electrode of the devices and propagate towards the centre. Thus, scattering and clear both states depend on the size of the device, and to obtain uniform performance higher voltage is required. Non uniform particles alignment may cause localised hot spots where arcing of the LC device occurs [296]. A semectic LC glazing achieved "opaque" state for $66 \mathrm{~V}$ and $100 \mathrm{~Hz}$ (rms) supply whereas $36 \mathrm{~V} 1 \mathrm{kHz}$ supplies produce "transparent" state. In this system, response time strongly depends on voltage [297]. Transmittance of a $12.5 \mathrm{~cm} \times 12.5 \mathrm{~cm}$ and $6 \mu \mathrm{m}$ thick LC material based glazing varied from $30 \%$ to $55 \%$ [298]. Organic-based SmA LC panel of $1 \times 1 \mathrm{~m}^{2}$ changing from a clear state to a fully scattered state by more than three orders to a few tens of milliseconds [296].

PDLC types as shown in Fig. 29 are best suitable over other types for glazing as it does not require polarizer to operate, high brightness (because of its high transparency), wide view angle, fast response (in the order of milliseconds), absence of surface treatment and the possibility of intermediate electrically controllable transmission levels [299]. In general, PDLC films consist lower molecular weight micro sized droplets liquid crystal within a solid polymer matrix. These composite materials are sandwiched between two transparent conducting electrodes. Because of the refractive index mismatch between the droplets and the polymer matrix, lights are scattered in the absence of power. Presence of power LC molecules orient in order to pass the light and refractive index between polymer matrix and droplets also match. Scattering from PDLC depends on the size of droplets. Droplets radius smaller than incident wavelength allow light to pass through without scattering. For large size droplets scattering is mainly forward type [300].

Thermal conductivity of PDLC film increases due to increase of applied electric filed as it enhances the thermal conductivity of the LC droplets. Increment rate depends on the concentration of LC in the composite and can be restricted [303]. This index method also depends on the temperature and the angle of incident light. PDLC
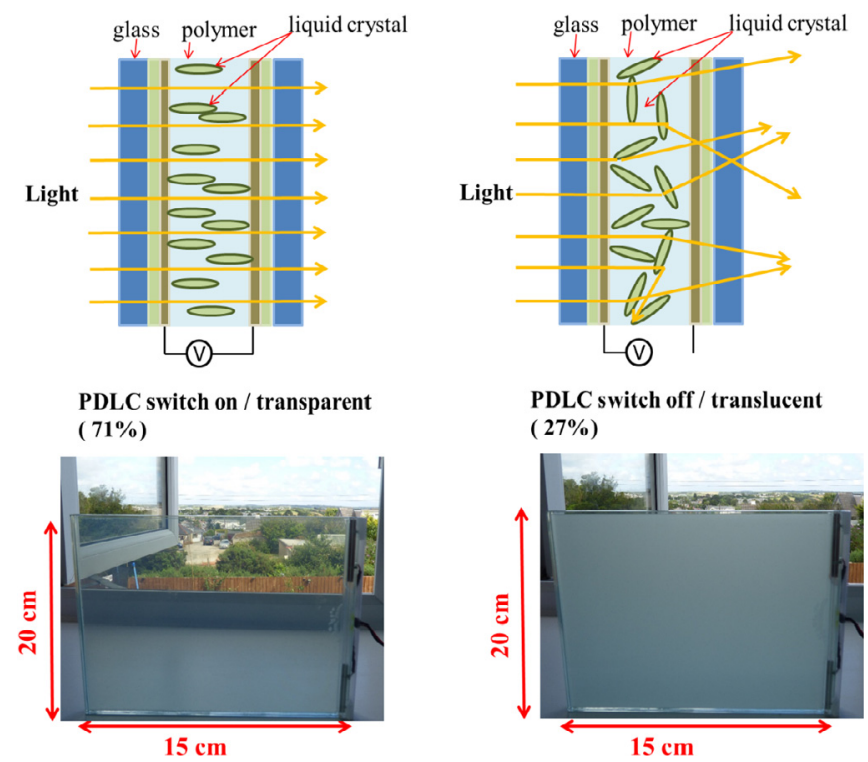

Fig. 29. The "transparent" and "translucent" states of a PDLC glazing (Taken from Ref. [301]) with permission from Elsevier.

Table 11

Thermal and visible transmission parameters for SPD glazing.

\begin{tabular}{|c|c|c|c|c|c|c|}
\hline Dimension $(\mathrm{m} \times \mathrm{m})$ & Type of glazing & States & $U$-value $\left(\mathrm{W} / \mathrm{m}^{2} \mathrm{~K}\right)$ & SHGC & Visible transmission & Reference \\
\hline \multirow[t]{2}{*}{$0.21 \mathrm{~m} \times 0.28 \mathrm{~m}$} & SPD single glazing & Transparent & 5.9 & 0.35 & $55 \%$ & {$[286,290]$} \\
\hline & & Opaque & 5.9 & 0.05 & $5 \%$ & \\
\hline \multirow[t]{2}{*}{$0.21 \mathrm{~m} \times 0.28 \mathrm{~m}$} & SPD double glazing & Transparent & 1.9 & Not available & Not available & \\
\hline & & Opaque & 1.9 & Not available & Not available & [286] \\
\hline \multirow[t]{2}{*}{$0.22 \mathrm{~m} \times 0.28 \mathrm{~m}$} & SPD single glazing & Transparent & NA & NA & $40 \%$ & [292] \\
\hline & & Opaque & NA & NA & $6 \%$ & \\
\hline
\end{tabular}


films can block $98 \%$ of UV; and modulate the NIR in the range between 12 and 38\% [304]. PDLC films have stability between $0{ }^{\circ} \mathrm{C}$ and $60^{\circ} \mathrm{C}$ temperature [305]. One PDLC film showed excellent durability up to 3 million times to electrical switching at $100 \mathrm{VAC}, 60 \mathrm{~Hz}$ with switching interval of $1 \mathrm{~s}$ [306]. Less thick LC material requires less switching time. Electro -optical switching effect of a $50 \mu \mathrm{m}$ thick PDLC film offered $190 \mu$ s rising time to be "transparent" and 2 ms day time when an external electric field was applied. Combined PDLC and electrochromic guest host molecules are able to offer fast switching from a scattering opaque state to a transmissive transparent state to control gain of incident daylight and glare [307,308]. Reverse mode PDLC glazing was also investigated which had transparent OFF state and opaque ON state. Switching of this devices was also possible using light source [309]. Daylight characterisation using PDLC glazing was investigated using outdoor test cell for Dublin weather condition. This glazing becomes $71 \%$ transparent in the presence of $20 \mathrm{~V}$ AC supply whereas becomes $27 \%$ transparent in the absence of power supply [301] as shown in Fig. 30. This particular type had $82.6 \%$ haze [310,311]. For clear sunny day, PDLC glazing was unable to control glare for both transparent and translucent states. For intermittent cloudy and overcast cloudy day PDLC glazing performance was acceptable to control glare [301].

Indium tin oxide (ITO) based transparent electrode is the most commonly used electrode for PDLC glazing. PDLC glazing is generally intended to apply for large scale glazing application $\left(1 \mathrm{~m}^{2}\right)$ and for that big surface area ITO becomes costly [312]. Also for glazing, PDLC film substrates are plastic rather than glass. ITO deposition temperature is suitable for plastic substrate [312]. This issues can be solved using silver nano wire type electrode as they are cheaper than ITO, mechanically flexible, deposition is possible at room temperature using roll to roll fabrication [313]. It also offers high transparency at infra-red wavelengths [314], perfectly suitable for solar control glazing. From experiment it was also found that $58.5 \%$ specular transmittance was possible at $50 \mathrm{~V}$ for silver

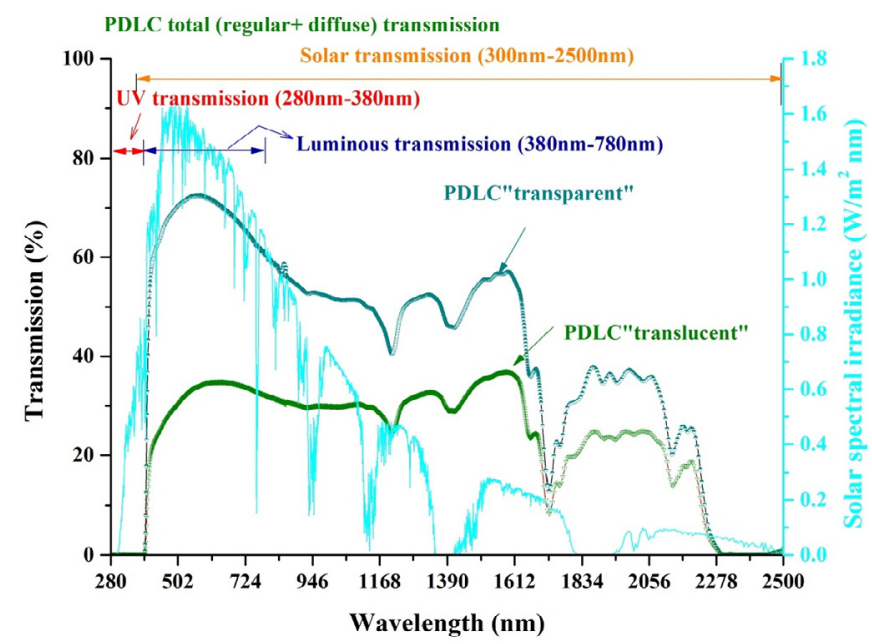

Fig. 30. Transmission spectra of a particular PDLC glazing in its "translucent" and "transparent" states. Taken from Ref. [302] with permission from Elsevier. nanowire based PDLC whereas while the ITO-based device needs $85 \mathrm{~V}$ to obtain $50.5 \%$ transmission.

LC glazing made of PDLC films possesses some disadvantages. PDLC films need a continuous power supply to remain "transparent" and provide haze due to scattering at wider viewing angles in transparent state. The scattering occurs in PDLCs due to the refractive index difference between the liquid crystal droplets and the polymer matrix where they are suspended. Reduction of droplet diameter maximizes the scattering, though it needs more driving voltage. PDLC films scatter blue and green light efficiently due to reduction of droplet size though transmit red light without significant scatter [297]. PDLC needs high driving voltage and presence of haze, which offer considerable amount of scattering and unwanted yellowing due to UV ageing. Thus, PDLC glazing systems can be less attractive choice for building engineer and architect for building application. Replacement of polymer to glass (glass disposed LC/GDLC) was investigated to reduce those aforementioned effects. One $5 \times 5 \mathrm{~cm}^{2}$ GDLC device was fabricated which offered 10 times lower switching time and $85 \%$ low voltage $(15 \mathrm{~V})$ to achieve $80 \%$ transmission compared to similar PDLC device [315]. Table 12 shows the literature data of PDLC glazing.

Presently EC, SPD and LC are the three electrically activated switchable glazing systems. SPD and LC require high AC voltage that can vary between $10 \mathrm{~V}-110 \mathrm{~V}$ to become transparent. This requirement is higher than EC glazing's voltage requirement to operate. However, the root cause of this high voltage requirement is not well-documented work. Layer by layer investigation is required to enlighten the thickness dependent or material dependent voltage requirement. Table 13 summarised the comparison between three electrically activated switchable EC, SPD and LC types glazing.

\section{Combined glazing}

Described glazing systems in the above sections are applicable only for specific application. In general, buildings in most of the location around the world, experience high to medium cooling load demand in summer and medium to high heating load demand in winter due to variable weather. Thus, alone solar heat gain control or low heat loss glazing in a building is not capable to reduce building energy consumption. Work has been performed to achieve combined effect such as heat loss and heat gain reduction using vacuum -electrochromic (EC) or vacuum -suspended particle device (SPD) glazing. External power supply requirement for an electrically activated glazing can be reduced integration of PV. PV integrated electrically activated switchable enables fossil fuel generated electricity free glazing actuation, which trigger to modulate from opaque to transparent state or reverse depending upon indoor and outdoor ambient conditions. These combined technologies are promising approach for switchable/smart/dynamic/adaptable glazing. PV integrated all three electrically activated switchable glazing systems were investigated by various research groups. Description of this combined technologies are discussed in this section.

Table 12

Literature data for polymer dispersed liquid crystal glazings.

\begin{tabular}{|c|c|c|c|c|c|c|}
\hline Dimension $(\mathrm{m} \times \mathrm{m})$ & Type of glazing & States & $U$-value $\left(\mathrm{W} / \mathrm{m}^{2} \mathrm{~K}\right)$ & SHGC & Visible transmission & Reference \\
\hline $0.2 \times 0.15$ & PDLC & Transparent & NA & 0.53 & $71 \%$ & [302] \\
\hline & & Translucent & & 0.39 & $27 \%$ & \\
\hline
\end{tabular}


Table 13

Comparison of electrochromic, liquid crystal, and suspended particle device type glazing.

\begin{tabular}{|c|c|c|c|}
\hline Properties & Electrochromic (EC) & Liquid crystal (LC) & Suspended particle device (SPD) \\
\hline Power & DC powered, voltage varies between 0 and $10 \mathrm{~V}$ & $\begin{array}{l}\text { AC powered, voltage varies between } 10 \text { and } \\
110 \mathrm{~V}\end{array}$ & $\begin{array}{l}\text { AC powered, voltage varies between } 10 \text { and } \\
110 \mathrm{~V}\end{array}$ \\
\hline Powered states & Opaque or coloured & Transparent & Transparent \\
\hline Unpowered states & Transparent & Opaque or translucent & Opaque or coloured \\
\hline $\begin{array}{l}\text { Requirement of } \\
\text { power }\end{array}$ & $\begin{array}{l}\text { Power required to obtain opaque and } \\
\text { transparent state }\end{array}$ & Power required to obtain transparent state & Power required to obtain transparent state \\
\hline Contrast ratio & $\begin{array}{l}\text { Transmission ratio between opaque and } \\
\text { transparent state is high }\end{array}$ & $\begin{array}{l}\text { Transmission ratio between opaque and } \\
\text { transparent state is low as opaque/translucent } \\
\text { state offers high diffuse transmission }\end{array}$ & $\begin{array}{l}\text { High transmission ratio between opaque and } \\
\text { transparent state }\end{array}$ \\
\hline Memory & $\begin{array}{l}\text { without supply "opaque" state still remain for } \\
\text { few hours }\end{array}$ & $\begin{array}{l}\text { No memory, Without supply it becomes } \\
\text { "opaque" }\end{array}$ & $\begin{array}{l}\text { No memory, Without supply it becomes } \\
\text { "opaque" }\end{array}$ \\
\hline Switching speed & $\begin{array}{l}\text { Take several seconds or minutes depends on the } \\
\text { area }\end{array}$ & Fast switching, Few seconds & Fast switching, Few seconds \\
\hline Durability & $\sim 10^{5}$ & $\sim 10$ millions & $\sim 10$ millions \\
\hline NIR control & Possible to control NIR & Transmit NIR & Transmit NIR \\
\hline Intermediate states & $\begin{array}{l}\text { Controllable intermediate states between } \\
\text { transparent and opaque states }\end{array}$ & $\begin{array}{l}\text { Controllable intermediate states between } \\
\text { transparent and opaque/translucent states }\end{array}$ & $\begin{array}{l}\text { Controllable intermediate states between } \\
\text { transparent and opaque states }\end{array}$ \\
\hline$U$-value & Similar to single glazing & NA & Similar to single glazing \\
\hline SHGC & $\begin{array}{l}\text { Variation of SGHC for both states are high due to } \\
\text { high contrast ratio }\end{array}$ & $\begin{array}{l}\text { Variation of SGHC between both states are low } \\
\text { due to low contrast ratio }\end{array}$ & $\begin{array}{l}\text { Variation of SGHC between both states are high } \\
\text { due to high contrast ratio }\end{array}$ \\
\hline Daylight/glare & $\begin{array}{l}\text { Possible to control glare using intermediate } \\
\text { state and opaque state }\end{array}$ & $\begin{array}{l}\text { Possible to control glare using opaque/ } \\
\text { translucent state }\end{array}$ & $\begin{array}{l}\text { Possible to control glare using intermediate and } \\
\text { opaque state }\end{array}$ \\
\hline
\end{tabular}

\subsection{Low heat loss switchable glazing}

\subsubsection{Vacuum -electrochromic}

Vacuum glazing and electrochromic glazing have been combined to achieve low heat loss, solar heat gain control and daylight all together as shown in Fig. 31 [316].

This device was fabricated using three glass panes where two glass panes were separated with a vacuum and the other glass panes having a small layer of EC are sealed with the vacuum glazing. This $0.4 \mathrm{~m} \times 0.4 \mathrm{~m}$ vacuum-EC device [316] achieved variable transparency from $63 \%$ to $2 \%$ with a mid-pane $U$-value of $0.86 \mathrm{~W} / \mathrm{m}^{2} \mathrm{~K}$. From theoretical investigation it was recommended that EC layer should always face the outside environment to avoid intolerable over heating [317] of an EC -vacuum glazing. During opaque state of EC layer, the absorbed solar radiations works as a

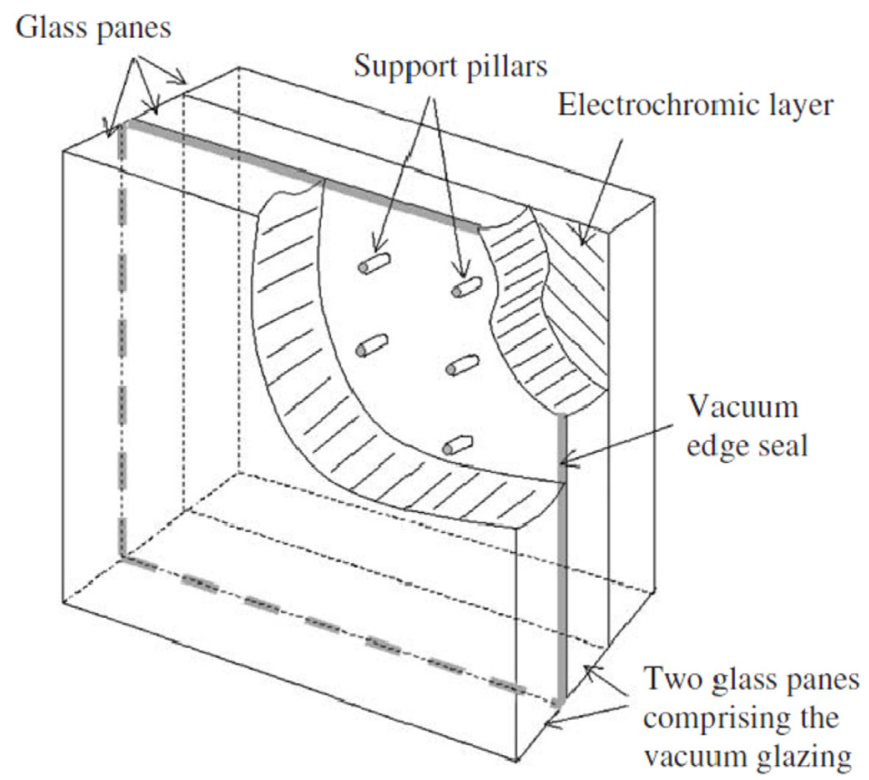

Fig. 31. Schematic diagram of EC-Vacuum glazing. Reprinted from Ref. [317] with permission from Elsevier. heat source and transmit heat to the inside of the room. Addition of low emittance layer with the vacuum gap on the glass panes also works as heat source with EC and it was found that using two low-e coating is not effective compare to one low-e coating [318-320].

\subsubsection{Vacuum - SPD}

Combined effect of vacuum and SPD was investigated attached in a south facing test cell [76,321]. SPD glazing was kept in two different positions for this combined glazing. First one where SPD glazing faced the exterior environment and vacuum glazing faced the interior test cell environment and second one where SPD glazing faced the interior test cell environment and vacuum glazing faced the exterior ambient environment as shown in Fig. 32. Dynamic transmission range from $2 \%$ (opaque state) to $38 \%$ (transparent state) was achieved by this combined glazing system as shown in Fig. 33.

Vacuum glazing surface temperature was always lower than SPD glazing surface temperature. $U$-value for this combined glazing was significantly low and varied between 1.00 and $1.16 \mathrm{~W} / \mathrm{m}^{2} \mathrm{~K}$. SHGC of this type of glazing varied from 0.045 to 0.26 . Variation of $U$-value and SHGC was due to the SPD glazing opaque and transparent state [76]. From vacuum-EC glazing, it was recommended that EC layer should always be outside to overcome from overheating. However, from vacuum -SPD glazing experiment, it was found that SPD glazing facing the outdoor ambient environment or facing the indoor test cell environment had negligible impact on test cell internal or glazing surface temperature.

Recommendation for vacuum EC was predicted from theoretical performance where ambient temperature was constant [319]. That could be the reason to achieve higher surface temperature when EC layer was placed inside.

\subsection{Self-powered switchable glazing}

A large area of EC glazing can be PV powered (i) to avoid the additional electricity load increasing the amount of grid supplied electricity consumed (ii) to give a readily installed autonomous device (iii) reliable long-term performance. 

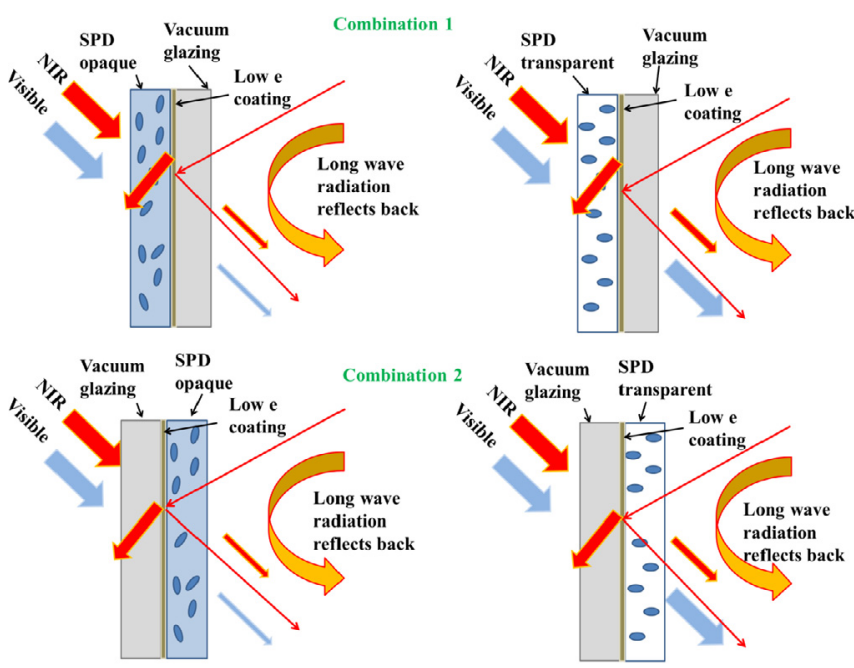

SPD vacuum

0V, $2 \%$ transparent
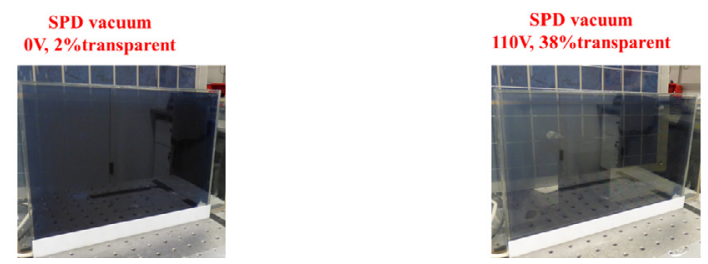

Fig. 32. Schematic and photograph of combined SPD-vacuum glazing Reprinted from Ref. [76] with permission from Elsevier Ltd.

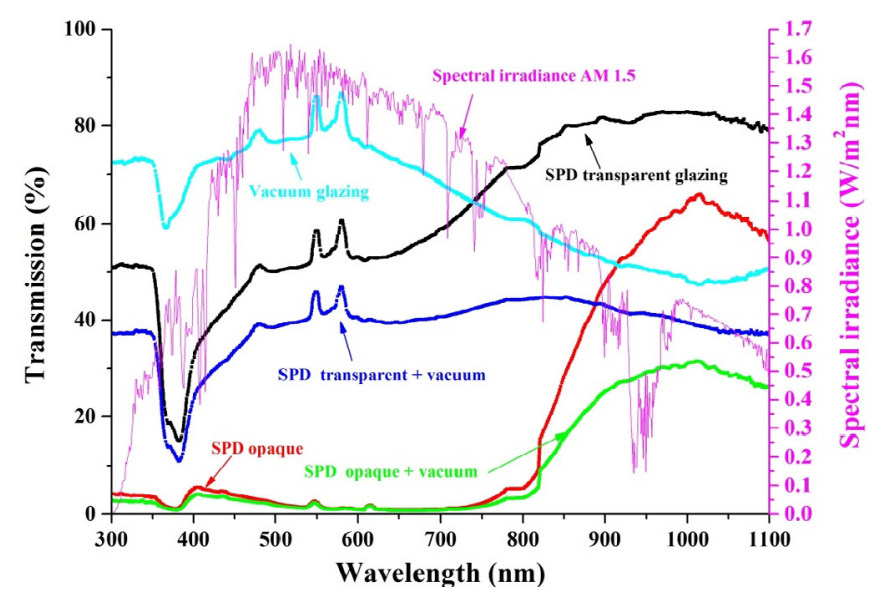

Fig. 33. Hemispherical spectral response of SPD vacuum glazing for SPD opaque and transparent states. Reprinted from Ref. [76] with permission from Elsevier Ltd.

\subsubsection{PV powered electrochromic}

Combining of PV-EC device was first explored for an electrophotographic application [322]. Coupling of PV-EC are advantageous because (i) Photovoltaic (PV) device generates DC power, which matches the use of DC by EC, (ii) EC and PV temperature characteristics are matched; at high temperature PV device efficiency drops which enhance the reduction of maximum power output [323,324]. For crystalline PV above $25^{\circ} \mathrm{C}$ its power drops with a coefficient between $0.4 \% / \mathrm{K}$ to $0.65 \% / \mathrm{K}$ [325]. At higher temperatures due to higher ion mobility, switching responses of EC devices are faster which reduce the amount of required voltage [280,281]. Fig. 34 illustrates the different combination of these types of PV-EC. Fig. 35 indicates the PV-EC device where the upper

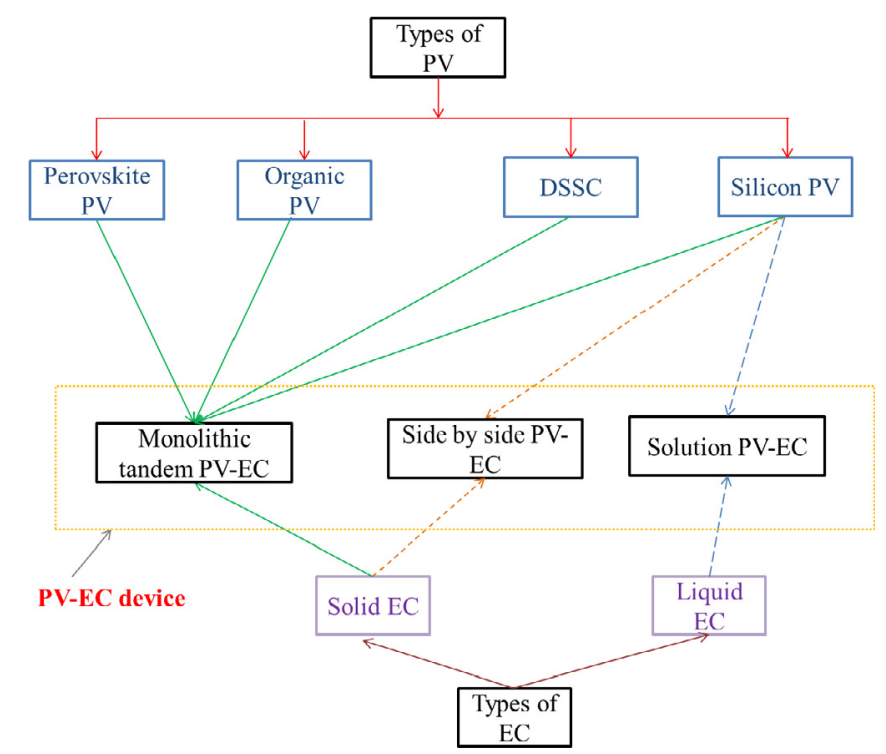

Fig. 34. Different PV-EC combination.

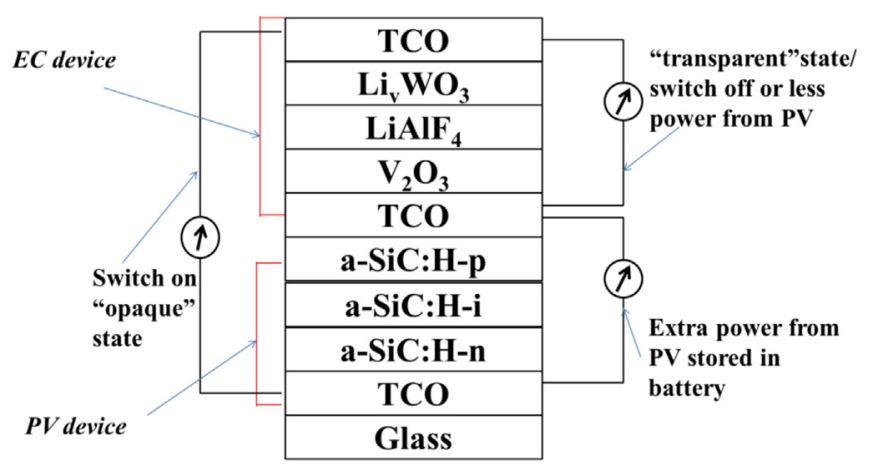

Fig. 35. Schematic diagram of PV -EC device (Redrwan from Ref. [234]).

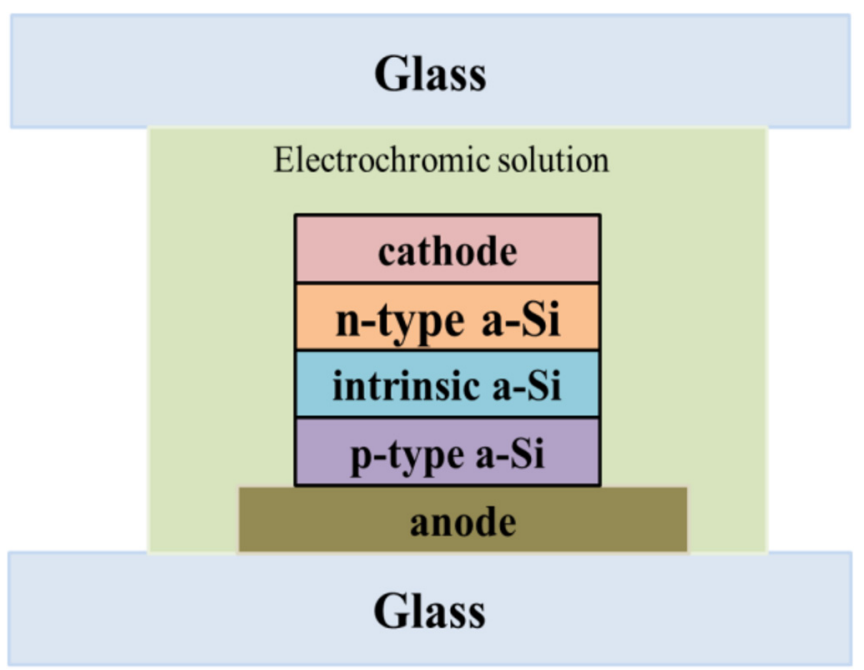

Fig. 36. Solution type PV -EC device.

half is the EC and the lower half is the PV. The middle contact permits battery and user control. 


\section{Classification based on types of PV}

- Dye sensitized solar cell (DSSC) based PV -EC device [326-330] are potentially low-cost devices with a good match to typical diffuse solar spectra. However, they can have low stability due to photochemical degradation [331].

- The critical issue in silicon based PV-EC device [329,332-335] development lies in its low optical contrast in between opaque and transparent state. The transparency of the PV-EC device can be improved by the incorporation of wide band gap semitransparent amorphous silicon carbon alloy. However, as the semi-transparent PV thin films become very thin, electrical short circuit occurs easily that renders the PV-EC stacks inoperable [234,326].

- Semi-transparent perovskite photovoltaic and solid-state electrochromic cells enables solid-state photovoltachromic devices with $26 \%$ average visible transmittance and $3.7 \%$ maximum light power conversion efficiency has been reported for a new PV-EC device. Activating self-tinting, the average visible transmittance drops to $8.4 \%$ [336].

- Using two-inverted transparent organic PV, a solutionprocessed polymer vertically integrated EC-PV window has been reported [337]. The achievement of low intensity illumination of 0.25 sun with a switching time of 3-6 s had demonstrated the feasibility of the EC-PV in window applications under oblique illumination of the Sun.

\section{Classification based on EC}

- All the aforementioned four types of PV can be integrated with solid type EC materials.

- Locating as electrochromic solution between the transparent non-conductive substrate and the silicon-thin film solar cell ( $\mathrm{Si}$ TFSC) substrate give electrodes in the PV-EC device planarly distributed in the semi-transparent Si-TFSC substrate as shown in Fig. 36. This can create a uniform electric field which makes large area PV-EC modules feasible. The thin film PV cell can be very thin due to low power requirement of PV-EC so overall system will have higher transparency [338,339].

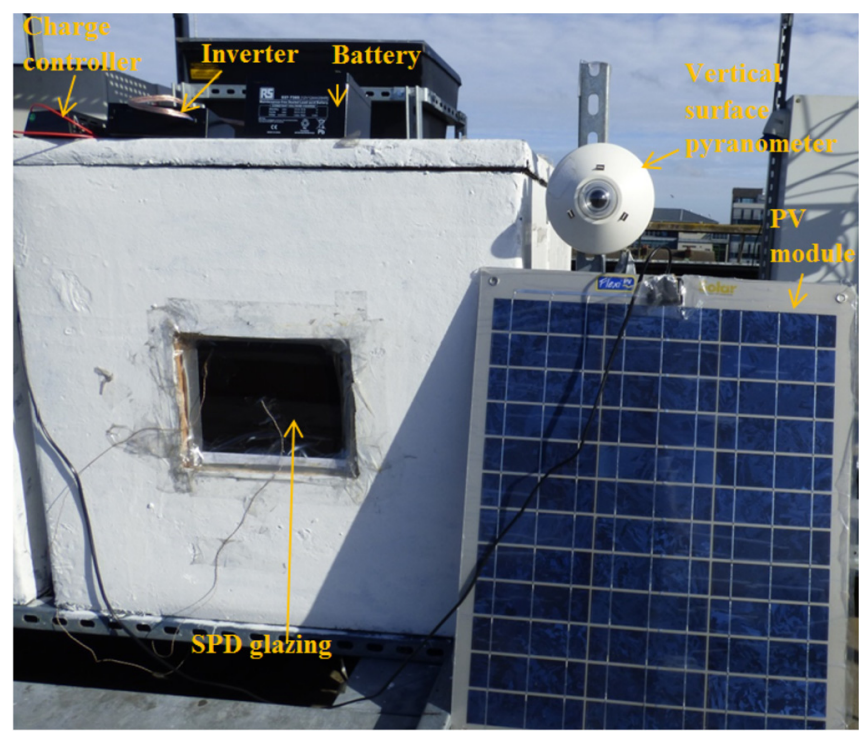

Fig. 37. Full view of experimental set up of PV powered SPD glazing. Reprinted from Ref. [346] with permission from Elsevier Ltd.
Tandem structure- DSSC [326] (Nokki et al., 2007) and hydrogenated amorphous silicon-carbon (a-SiC:H) photovoltaicpowered monolithic tandem EC device was reported [334]. Monolithic and monolithic tandem both reduce the overall transmittance of the system as sunlight passes through the both PV and EC [327,333,334]. Fabrication process of this tandem structure is also challenging [234]. To obtain higher transparency semitransparent PV is recommended which eventually reduces the overall cell efficiency [326]. However, no external wiring makes this type of device advantageous. For a side by-side PV-EC device, PV can be placed on the window frame [332] or PV can be building integrated photovoltaic (BIPV) types [340] [341]. Efficient opaque PV can be used as insolation is blocked by the PV device. Solution EC and PV type structures solve the short circuit problems encountered in the tandem PV-EC structures [234,334].

Presently this PV-EC technology is laboratory based and no commercial device has been manufactured [327,342]. However, work is still ongoing particularly photoelctrochromic where EC powered by DSSC [343-345].

\subsection{2. $P V$ powered $S P D$}

First experimentally potential of PV powered SPD glazing was investigated in Dublin. One $0.0588 \mathrm{~m}^{2}$ area of SPD glazing was powered by $0.3432 \mathrm{~m}^{2}$ vertical PV as shown in Fig. 37. This SPD glazing only take $0.07 \mathrm{~W}$ continuous $\mathrm{AC}$ power to keep the glazing transparent. As SPD glazing works with AC power and PV generates $D C$, conversion of DC to AC was done by using one inverter. It was found that though SPD glazing needs $110 \mathrm{~V}$ to operate but the power requirement is less. For a $1 \mathrm{~m}^{2}$ area of SPD glazing only takes $10.42 \mathrm{kWh}$ power for $24 \mathrm{~h}$ and 365 days. Presence of inverter between PV and SPD glazing makes the process complicated. To obtain higher power from PV inverter combination the sizing in ratio between PV power and inverter rating should be nearly 1 . To power SPD glazing few watts are sufficient but the low power rating inverter is not commercially available. Thus, high power rating PV needs to be installed. It can be concluded that for largescale SPD glazing PV powering is advantageous. For few meter square area SPD application PV powering is not advantageous due to losses of power [346].

Battery storage is essential for PV powered SPD application as SPD becomes clear in the presence of power supply. In the night there can be need to make it transparent. To obtain power from PV in the nighttime battery storage is required.

\subsection{3. $P V$ powered $L C$}

First PV powered LC device for glazing application was investigated where PV was DSSC type and LC was chiral nemetic type [347]. Three different structures were manufactured as shown in Fig. 38. To generate higher electricity first structure is suitable as DSSC gets uninterrupted solar radiation. From experiment it was also found that structure (a) (b) and (c) offered current density of $16.43,2.13,5.67 \mathrm{~mA} / \mathrm{cm}^{2}$ respectively. This device had maximum

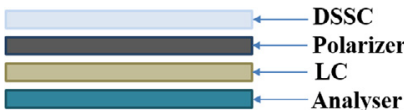

(a)

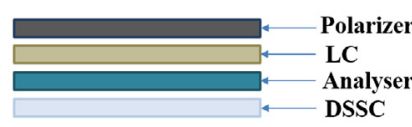

(b)
Polarizer

LC

DSSC

Analyser

Fig. 38. Schematic of three structure of PV powered LC. Redrawn from Ref. [347]. 
transmission around $550 \mathrm{~nm}$ wavelength and took 60s to become transparent with power density of $100 \mathrm{~mW} / \mathrm{cm}^{2}$.

\subsection{Low heat loss clean power generating glazing}

This type of glazing is the combination of low heat loss vacuum glazing and photovoltaic glazing. Double panes vacuum glazing allows higher penetration of daylight which is similar to double glazing [80]. Addition of electrically activated switchable material can restrict the entering higher daylight; however, they need power to operate. Static transparent photovoltaic can control the allowable solar gain, daylight whereas they also provide clean power rather than consuming power. Thus, PV-vacuum combination is advantageous as they limit the high penetration of daylight, offer low heat loss and generate renewable power. For crystalline silicon type PV cells, to achieve semitransparency type PV glazing, spaced type structure can be utilized. Transparent gap between regularly

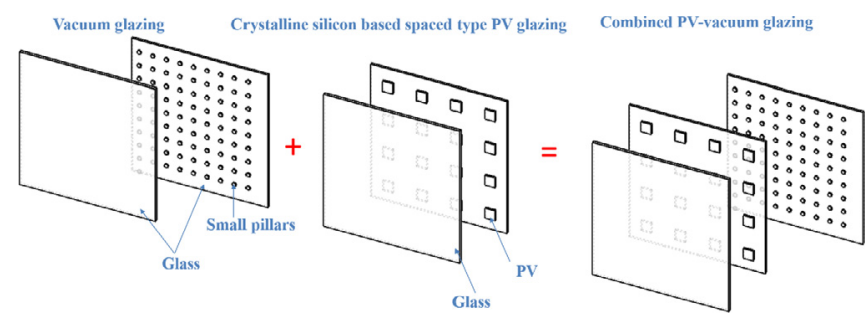

Fig. 39. Schematic details of crystalline silicon based spaced type PV-vacuum glazing.

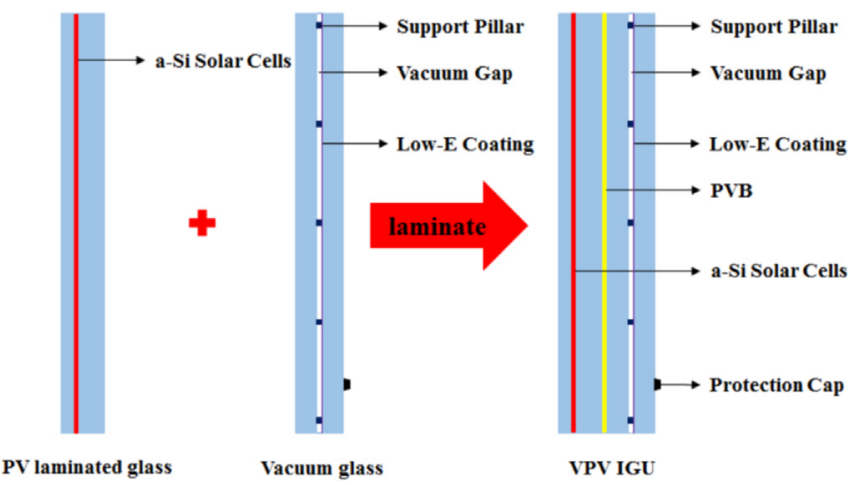

Fig. 40. Schematic structure of PV-vacuum glazing. Taken from Ref. [349]. distributed PV will admit daylight [348]. Crystalline silicon based spaced type PV-vacuum glazing is shown in Fig. 39.

Amorphous silicon based 20\% transparent laminated PV and one vacuum glazing with $U$-value of $0.8 \mathrm{~W} / \mathrm{m}^{2} \mathrm{~K}$ were attached together to form combined PV-vacuum glazing [349] as shown Fig. 40. Dimension of this PV -vacuum glazing was $1.3 \mathrm{~m}$ (width) $\times 1.100 \mathrm{~m}$ (height) $\times 2.087 \mathrm{~m}$ (thickness). Outdoor characterisation was performed using this device on the platform of Block $\mathrm{Z}$ in the Hong Kong Polytechnic University from June 2016. This combined system offered 0.08 transmittance. Maximum external glazing surface temperature was $75^{\circ} \mathrm{C}$ whereas internal maximum glazing surface temperature was $45^{\circ} \mathrm{C}$.

Table 14 compared advantages and disadvantages or future scope for different combined glazing systems.

\section{Conclusions}

To quantify a glazing performance for building application, the required glazing parameters are overall heat transfer coefficient $(U$ value), solar heat gain coefficient and daylight. Low overall heat transfer coefficient is possible by introducing multiple panes glasses with single glass, presence of thermally insulating material or vacuum between two glass panes. Solar heat gain depends on the visible and NIR spectrum of incident solar radiation whereas daylight only associated with visible spectrum. Present available glazings are low heat loss control and solar heat gain control glazing. Solar heat gain control glazing also has potential to control daylight.

Potential static transparent glazings are vacuum and aerogel as they both offer $U$-value lower or close to $1 \mathrm{~W} / \mathrm{m}^{2} \mathrm{~K}$. However, they have non-variable solar heat gain control. For glazing application vacuum is suitable, as they do not obstruct the viewing. Monolithic type aerogel is suitable for glazing; however, most of the present available aerogels are translucent granular type. Granular types block viewing but offer higher transmittance due to scattering. Further investigation is required to develop non-fragile transparent aerogel for glazing application.

For switchable glazing, control over switchable intermediate states, higher contrast ratio between opaque and transparent states, high durability, high luminous transmittance are the most essential criteria. Electrically activated switchable glazings meet most of the criteria over non-electrically activated switchable glazing. However, $U$-values are higher for double glazed switchable glazing compared to vacuum and aerogel. For diurnal variation of weather, glazings are required which can adapt with this variation. Thus, switchable transparent glazing is always preferable. To enable this glazing even for cold climate, integrating them with vacuum

Table 14

Comparison between different combined glazing systems.

\begin{tabular}{|c|c|c|c|}
\hline Combined glazing type & Combination & Advantage & Disadvantage/future scope \\
\hline \multirow[t]{2}{*}{$\begin{array}{l}\text { Low heat loss } \\
\text { switchable glazing }\end{array}$} & Vacuum -EC & Higher contrast ratio was found & $\begin{array}{l}\text { EC glass panes must be kept facing ambient weather. } \\
\text { However, that conclusion was made based on simulation } \\
\text { work under constant ambient temperature. }\end{array}$ \\
\hline & Vacuum -SPD & $\begin{array}{l}\text { Nearly equal temperature rise of SPD glazing for facing } \\
\text { indoor environment or outdoor environment }\end{array}$ & Low optical contrast between opaque and transparent state \\
\hline \multirow[t]{3}{*}{$\begin{array}{l}\text { Self-powered } \\
\text { switchable glazing }\end{array}$} & PV-EC & $\begin{array}{l}\text { Driving voltage of EC is low (typically } 1-5 \mathrm{~V} \text { ). } \\
\text { Direct coupling with PV is possible. }\end{array}$ & $\begin{array}{l}\text { Tandem structure of PV-EC reduces the overall transparency } \\
\text { of the glazing. }\end{array}$ \\
\hline & PV -SPD & $\begin{array}{l}\text { Low solar heat gain possible without switching. } \\
\text { Generated power from PV can be stored and will be used for }\end{array}$ & $\begin{array}{l}\text { Inverter requirement for PV powered SPD can make the } \\
\text { process complicated }\end{array}$ \\
\hline & PV-LC & low insolation or cloudy day or night time & $\begin{array}{l}\text { LC also need AC power and consequence will be similar to } \\
\text { SPD }\end{array}$ \\
\hline $\begin{array}{l}\text { Low heat loss clean } \\
\text { power generating } \\
\text { glazing }\end{array}$ & PV-Vacuum & $\begin{array}{l}\text { For cold climate heat loss reduction and power generation } \\
\text { both possible from a single glazing unit }\end{array}$ & $\begin{array}{l}\text { Presence of vacuum may rise the PV cell temperature } \\
\text { compared to glass-PV-glass structure. However, to validate } \\
\text { this comments experimental work is required }\end{array}$ \\
\hline
\end{tabular}


glazing is promising (low heat loss switchable glazing).

PV powered electrically activated glazing can be part of building energy management system (BEMS) [350]. For an intelligent building [351,352] glazing will be connected to the PV and its colour changes will be operated by BEMS based on specified criteria of buildings occupant's.

For future autonomous glazing technology, research should be focused on photovoltaic integrated electrically activated low heat loss switchable glazing. This type of combined technologies are still in research phase though they have ample potential for future fenestration application. PV powered electrically actuated switchable EC/SPD/PDLC-vacuum glazing can dominate the future building's glazing sector.

\section{Acknowledgements}

The work described in this paper was supported by the Graduate Research Education Programme of the Higher Education Authority, Ireland.

\section{References}

[1] P. Nejat, F. Jomehzadeh, M.M. Taheri, M. Gohari, M.Z. Muhd, A global review of energy consumption, $\mathrm{CO} 2$ emissions and policy in the residential sector (with an overview of the top ten $\mathrm{CO} 2$ emitting countries), Renew. Sustain. Energy Rev. 43 (2015) 843-862, https://doi.org/10.1016/j.rser.2014.11.066.

[2] K. Hara, M. Uwasu, Y. Kishita, H. Takeda, Determinant factors of residential consumption and perception of energy conservation: time-series analysis by large-scale questionnaire in Suita, Japan, Energy Pol. 87 (2015) 240-249, https://doi.org/10.1016/j.enpol.2015.09.016.

[3] Z. Ma, P. Cooper, D. Daly, L. Ledo, Existing building retrofits: methodology and state-of-the-art, Energy Build. 55 (2012) 889-902, https://doi.org/ 10.1016/j.enbuild.2012.08.018.

[4] D. Daly, P. Cooper, Z. Ma, Implications of global warming for commercial building retrofitting in Australian cities, Build. Environ. 74 (2014) 86-95 https://doi.org/10.1016/j.buildenv.2014.01.008.

[5] X. Wang, D. Chen, Z. Ren, Global warming and its implication to emission reduction strategies for residential buildings, Build. Environ. 46 (2011) 871-883, https://doi.org/10.1016/j.buildenv.2010.10.016.

[6] S. Ashina, T. Nakata, Energy-efficiency strategy for $\mathrm{CO} 2$ emissions in a residential sector in Japan, Appl. Energy 85 (2008) 101-114, https://doi.org/ 10.1016/j.apenergy.2007.06.011.

[7] H. Ren, W. Gao, W. Zhou, K. Nakagami, Multi-criteria evaluation for the optimal adoption of distributed residential energy systems in Japan, Energy Pol. 37 (2009) 5484-5493, https://doi.org/10.1016/j.enpol.2009.08.014.

[8] E. Commission, A Roadmap for Moving to a Competitive Low Carbon Economy in 2050, 2011.

[9] E. Commission, Communication from the Commission to the European Parliament, the Council, the European Economic and Social Committee and the Committee of the Regions - a Policy Framework for Climate and Energy in the Period from 2020 to 2030, 2014.

[10] M. Cellura, F. Guarino, S. Longo, M. Mistretta, Different energy balances for the redesign of nearly net zero energy buildings: an Italian case study Renew. Sustain. Energy Rev. 45 (2015) 100-112, https://doi.org/10.1016/ j.rser.2015.01.048.

[11] D. Kolokotsa, D. Rovas, E. Kosmatopoulos, K. Kalaitzakis, A roadmap towards intelligent net zero- and positive-energy buildings, Sol. Energy 85 (2011) 3067-3084, https://doi.org/10.1016/j.solener.2010.09.001.

[12] L. Wang, J. Gwilliam, P. Jones, Case study of zero energy house design in UK Energy Build. 41 (2009) 1215-1222, https://doi.org/10.1016 j.enbuild.2009.07.001.

[13] E. Gratia, A. De Herde, Design of low energy office buildings, Energy Build. 35 (2003) 473-491, https://doi.org/10.1016/S0378-7788(02)00160-3.

[14] Y. Xing, N. Hewitt, P. Griffiths, Zero carbon buildings refurbishment - a Hierarchical pathway, Renew. Sustain. Energy Rev. 15 (2011) 3229-3236, https://doi.org/10.1016/j.rser.2011.04.020.

[15] A.M.T. Martins, J.S. Carlos, The retrofitting of the bernardas' convent in lisbon, Energy Build. 68 (2014) 396-402, https://doi.org/10.1016/ j.enbuild.2013.07.087.

[16] M. Morelli, L. Rønby, S.E. Mikkelsen, M.G. Minzari, T. Kildemoes, H.M. Tommerup, Energy retrofitting of a typical old Danish multi-family building to a "nearly-zero" energy building based on experiences from a test apartment, Energy Build. 54 (2012) 395-406, https://doi.org/10.1016/ j.enbuild.2012.07.046.

[17] J.N.J. Klainsek, C. Bedoya, The effect of glazing shape upon the thermal performance of buildings, Renew. Energy 8 (1996) 182-185.

[18] Y. Yildiz, Z.D. Arsan, Identification of the building parameters that influence heating and cooling energy loads for apartment buildings in hot-humid climates, Energy 36 (2011) 4287-4296, https://doi.org/10.1016/ j.energy.2011.04.013.

[19] M. Takashi, H. Shuichi, O. Daisuke, T. Masahiko, S. Jun, Improvement of thermal environment and reduction of energy consumption for cooling and heating by retrofitting windows, Front. Archit. Res. 2 (2013) 1-10, https:// doi.org/10.1016/j.foar.2012.10.006.

[20] E. Rodriguez-Ubinas, B.A. Arranz, S. Vega Sánchez, F.J. Neila González, Influence of the use of PCM drywall and the fenestration in building retrofitting, Energy Build. 65 (2013) 464-476, https://doi.org/10.1016/ j.enbuild.2013.06.023.

[21] M. Harrestrup, S. Svendsen, Full-scale test of an old heritage multi-storey building undergoing energy retrofitting with focus on internal insulation and moisture, Build. Environ. 85 (2015) 123-133, https://doi.org/10.1016/ j.buildenv.2014.12.005.

[22] B.P. Jelle, Solar radiation glazing factors for window panes, glass structures and electrochromic windows in buildings - measurement and calculation, Sol. Energy Mater. Sol. Cells 116 (2013) 291-323, https://doi.org/10.1016/ j.solmat.2013.04.032.

[23] T.E. Kuhn, Calorimetric determination of the solar heat gain coefficient $g$ with steady-state laboratory measurements, Energy Build. 84 (2014) 388-402, https://doi.org/10.1016/j.enbuild.2014.08.021.

[24] P. Littlefair, Daylight prediction in atrium buildings, Sol. Energy 73 (2002) 105-109, https://doi.org/10.1016/S0038-092X(02)00038-5.

[25] P. Littlefair, Daylight, sunlight and solar gain in the urban environment, Sol. Energy 70 (2001) 177-185, https://doi.org/10.1016/S0038-092X(00)000992.

[26] P.J. Littlefair, M.E. Aizlewood, A.B. Birtles, The performance of innovative daylighting systems, Renew. Energy 5 (1994) 920-934, https://doi.org/ 10.1016/0960-1481(94)90113-9.

[27] P.J. Littlefair, Predicting annual lighting use in daylit buildings, Build. Environ. 25 (1990) 43-53, https://doi.org/10.1016/0360-1323(90)90040-X

[28] P. Littlefair, The luminous efficacy of daylight: a review, Light. Res. Technol. 17 (1985) 162-182.

[29] M. Bodart, A. De Herde, Global energy savings in offices buildings by the use of daylighting, Energy Build. 34 (2002) 421-429, https://doi.org/10.1016/ S0378-7788(01)00117-7.

[30] J.C. Lam, D.H.W. Li, An analysis of daylighting and solar heat for coolingdominated office buildings, Sol. Energy 65 (1999) 251-262, https://doi.org/ 10.1016/S0038-092X(98)00136-4.

[31] A. Zain-Ahmed, K. Sopian, M.Y. Othman, A.A. Sayigh, P. Surendran, Daylighting as a passive solar design strategy in tropical buildings: a case study of Malaysia, Energy Convers. Manag. 43 (2002) 1725-1736, https:// doi.org/10.1016/S0196-8904(01)00007-3.

[32] W.J. Hee, M.A. Alghoul, B. Bakhtyar, O. Elayeb, M.A. Shameri, M.S. Alrubaih, $\mathrm{K}$. Sopian, The role of window glazing on daylighting and energy saving in buildings, Renew. Sustain. Energy Rev. 42 (2015) 323-343, https://doi.org/ 10.1016/j.rser.2014.09.020.

[33] F. Favoino, M. Overend, Q. Jin, The optimal thermo-optical properties and energy saving potential of adaptive glazing technologies, Appl. Energy 156 (2015) 1-15, https://doi.org/10.1016/j.apenergy.2015.05.065.

[34] B.P. Jelle, A. Hynd, A. Gustavsen, D. Arasteh, H. Goudey, R. Hart, Fenestration of today and tomorrow: a state-of-the-art review and future research opportunities, Sol. Energy Mater. Sol. Cells 96 (2012) 1-28, https://doi.org/ 10.1016/j.solmat.2011.08.010.

[35] S.D. Rezaei, S. Shannigrahi, S. Ramakrishna, A review of conventional, advanced, and smart glazing technologies and materials for improving indoor environment, Sol. Energy Mater. Sol. Cells 159 (2017) 26-51, https:// doi.org/10.1016/j.solmat.2016.08.026.

[36] G. Gorgolis, D. Karamanis, Solar energy materials for glazing technologies, Sol. Energy Mater. Sol. Cells 144 (2016) 559-578, https://doi.org/10.1016/ j.solmat.2015.09.040.

[37] R. Baetens, B.P. Jelle, A. Gustavsen, Properties, requirements and possibilities of smart windows for dynamic daylight and solar energy control in buildings: a state-of-the-art review, Sol. Energy Mater. Sol. Cells 94 (2010) 87-105, https://doi.org/10.1016/j.solmat.2009.08.021.

[38] A. Seeboth, J. Schneider, A. Patzak, Materials for intelligent sun protecting glazing, Sol. Energy Mater. Sol. Cells 60 (2000) 263-277, https://doi.org/ 10.1016/S0927-0248(99)00087-2.

[39] M. Arici, H. Karabay, Determination of optimum thickness of double-glazed windows for the climatic regions of Turkey, Energy Build. 42 (2010) 1773-1778, https://doi.org/10.1016/j.enbuild.2010.05.013.

[40] O. Aydin, Determination of optimum air-layer thickness in double-pane windows, Energy Build. 32 (2000) 303-308, https://doi.org/10.1016/ S0378-7788(00)00057-8.

[41] O. Aydin, Conjugate heat transfer analysis of double pane windows, Build. Environ. 41 (2006) 109-116, https://doi.org/10.1016/j.buildenv.2005.01.011.

[42] K.A.R. Ismail, J.R. Henríquez, Two-dimensional model for the double glass naturally ventilated window, Int. J. Heat Mass Tran. 48 (2005) 461-475, https://doi.org/10.1016/j.ijheatmasstransfer.2004.09.022.

[43] K.A.R. Ismail, C. Salinas, Non-gray radiative convective conductive modeling of a double glass window with a cavity filled with a mixture of absorbing gases, Int. J. Heat Mass Tran. 49 (2006) 2972-2983, https://doi.org/10.1016/ j.ijheatmasstransfer.2006.01.051.

[44] K.A.R. Ismail, C.T. Salinas, J.R. Henriquez, A comparative study of naturally ventilated and gas filled windows for hot climates, Energy Convers. Manag. 
50 (2009) 1691-1703, https://doi.org/10.1016/j.enconman.2009.03.026.

[45] J.S. Carlos, H. Corvacho, Evaluation of the performance indices of a ventilated double window through experimental and analytical procedures: SHGCvalues, Energy Build. 86 (2015) 886-897, https://doi.org/10.1016/ j.enbuild.2014.11.002.

[46] B.P. Jelle, S.E. Kalnæs, T. Gao, Low-emissivity materials for building applications: a state-of-the-art review and future research perspectives, Energy Build. 96 (2015) 329-356, https://doi.org/10.1016/j.enbuild.2015.03.024.

[47] H. Ye, X. Meng, L. Long, B. Xu, The route to a perfect window, Renew. Energy 55 (2013) 448-455, https://doi.org/10.1016/j.renene.2013.01.003.

[48] J. Han, L. Lu, H. Yang, Numerical evaluation of the mixed convective heat transfer in a double-pane window integrated with see-through a-Si PV cells with low-e coatings, Appl. Energy 87 (2010) 3431-3437, https://doi.org/ 10.1016/j.apenergy.2010.05.025

[49] H. Bulow- Hube, Subjective reactions to daylight in rooms: effect of using low-emittance coatings on windows, Light. Res. Technol. 27 (1995) 37-44.

[50] K. Chiba, T. Takahashi, T. Kageyama, H. Oda, Low-emissivity coating of amorphous diamond-like carbon/Ag-alloy multilayer on glass, Appl. Surf. Sci. 246 (2005) 48-51, https://doi.org/10.1016/j.apsusc.2004.10.046.

[51] G. Leftheriotis, P. Yianoulis, Characterization and stability of low-emittance multiple coatings for glazing applications, Sol. Energy Mater. Sol. Cells 58 (1999) 185-197, https://doi.org/10.1016/S0927-0248(98)00202-5.

[52] M. Reidinger, M. Rydzek, C. Scherdel, M. Arduini-Schuster, J. Manara, Lowemitting transparent coatings based on tin doped indiumoxide applied via a sol-gel routine, Thin Solid Films 517 (2009) 3096-3099, https://doi.org/ 10.1016/j.tsf.2008.11.078.

[53] E. Hammarberg, A. Roos, Antireflection treatment of low-emitting glazings for energy efficient windows with high visible transmittance, Thin Solid Films 442 (2003) 222-226, https://doi.org/10.1016/S0040-6090(03)009866.

[54] M. Del Re, R. Gouttebaron, J.P. Dauchot, M. Hecq, Study of the optical properties of AIN/ZrN/AIN low-e coating, Surf. Coating. Technol. 180-181 (2004) 488-495, https://doi.org/10.1016/j.surfcoat.2003.10.093.

[55] W. Lorenz, Glazing unit for solar control, daylighting and energy conservation, Sol. Energy 70 (2001) 109-130, https://doi.org/10.1016/S0038092X(00)00132-8.

[56] D. Christoffers, Seasonal shading of vertical south-facades with prismatic panes, Sol. Energy 57 (1996) 339-343, https://doi.org/10.1016/S0038092X(96)00112-0.

[57] E.J. Gago, T. Muneer, M. Knez, H. Köster, Natural light controls and guides in buildings. Energy saving for electrical lighting, reduction of cooling load, Renew. Sustain. Energy Rev. 41 (2015) 1-13, https://doi.org/10.1016/ j.rser.2014.08.002.

[58] P. Sierra, J.A. Hernández, Solar heat gain coefficient of water flow glazings, Energy Build. 139 (2017) 133-145, https://doi.org/10.1016/ j.enbuild.2017.01.032.

[59] T. tai Chow, C. Li, Z. Lin, Innovative solar windows for cooling-demand climate, Sol. Energy Mater. Sol. Cells 94 (2010) 212-220, https://doi.org/ 10.1016/j.solmat.2009.09.004.

[60] T.T. Chow, C. Li, Liquid-filled solar glazing design for buoyant water-flow, Build. Environ. 60 (2013) 45-55, https://doi.org/10.1016/ j.buildenv.2012.11.010.

[61] T.T. Chow, C. Li, Z. Lin, Thermal characteristics of water-flow double-pane window, Int. J. Therm. Sci. 50 (2011) 140-148, https://doi.org/10.1016/ j.ijthermalsci.2010.10.006.

[62] T.T. Chow, C. Li, Z. Lin, The function of solar absorbing window as waterheating device, Build, Environ. Times 46 (2011) 955-960, https://doi.org/ 10.1016/j.buildenv.2010.10.027.

[63] T. Gil-Lopez, C. Gimenez-Molina, Influence of double glazing with a circulating water chamber on the thermal energy savings in buildings, Energy Build. 56 (2013) 56-65, https://doi.org/10.1016/j.enbuild.2012.10.008.

[64] T. Gil-Lopez, C. Gimenez-Molina, Environmental, economic and energy analysis of double glazing with a circulating water chamber in residential buildings, Appl. Energy 101 (2013) 572-581, https://doi.org/10.1016/ j.apenergy.2012.06.055.

[65] A. Qahtan, S.P. Rao, N. Keumala, The effectiveness of the sustainable flowing water film in improving the solar-optical properties of glazing in the tropics, Energy Build. 77 (2014) 247-255, https://doi.org/10.1016 j.enbuild.2014.03.051.

[66] X. Romero, J.A. Hernández, Spectral problem for water flow glazings, Energy Build. 145 (2017) 67-78, https://doi.org/10.1016/j.enbuild.2017.03.013.

[67] G. Yuill, Laminar airflow super window, Renew. Energy Branch, Energy Mines Resour. Canada (1987).

[68] J.L. Wright, Effective U-values and shading coefficients of preheat/supply air glazing systems, in: Proc. Renew. Energy Conf. Winnipeg, Manitob, 1986.

[69] P. Baker, M. McEvoy, Test cell analysis of the use of a supply air window as a passive solar component, Sol. Energy 69 (2000) 113-130, https://doi.org/ 10.1016/S0038-092X(00)00048-7.

[70] M.E. McEvoy, R.G. Southall, P.H. Baker, Test cell evaluation of supply air windows to characterise their optimum performance and its verification by the use of modelling techniques, Energy Build. 35 (2003) 1009-1020, https://doi.org/10.1016/S0378-7788(03)00042-2.

[71] R.G. Southall, M.E. McEvoy, Investigations into the functioning of a supply air window in relation to solar energy as determined by experiment and simulation, Sol. Energy 80 (2006) 512-523, https://doi.org/10.1016/ j.solener.2005.04.016.

[72] J. Wei, J. Zhao, Q. Chen, in: Energy Performance of a Dual Airflow Window under Different Climates, vol. 42, 2010, pp. 111-122, https://doi.org 10.1016/j.enbuild.2009.07.018

[73] J.R. Gosselin, Q.Y. Chen, in: A Computational Method for Calculating Heat Transfer and Airflow through a Dual-airflow Window, vol. 40, 2008, pp. 452-458, https://doi.org/10.1016/j.enbuild.2007.03.010.

[74] J.S. Carlos, H. Corvacho, Evaluation of the thermal performance indices of a ventilated double window through experimental and analytical procedures: uw-values, Renew. Energy 63 (2014) 747-754, https://doi.org/10.1016 j.renene.2013.10.031.

[75] F. Gloriant, P. Tittelein, A. Joulin, S. Lassue, Modeling a triple-glazed supplyair window, Build. Environ. 84 (2015) 1-9, https://doi.org/10.1016/ j.buildenv.2014.10.017.

[76] A. Ghosh, B. Norton, A. Duffy, Measured thermal performance of a combined suspended particle switchable device evacuated glazing, Appl. Energy 169 (2016) 469-480, https://doi.org/10.1016/j.apenergy.2016.02.031.

[77] E. Cuce, P.M. Cuce, Vacuum glazing for highly insulating windows: recent developments and future prospects, Renew. Sustain. Energy Rev. 54 (2016) 1345-1347, https://doi.org/10.1016/j.rser.2015.10.134.

[78] Y. Fang, T.J. Hyde, F. Arya, N. Hewitt, P.C. Eames, B. Norton, S. Miller, Indium alloy-sealed vacuum glazing development and context, Renew. Sustain. Energy Rev. 37 (2014) 480-501, https://doi.org/10.1016/j.rser.2014.05.029.

[79] R.E. Collins, G.M. Turner, A.C. Fischer-Cripps, J.Z. Tang, T.M. Simko, C.J. Dey, D.A. Clugston, Q.C. Zhang, J.D. Garrison, Vacuum glazing-A new component for insulating windows, Build. Environ. 30 (1995) 459-492, https://doi.org/ 10.1016/0360-1323(95)00025-2.

[80] A. Ghosh, B. Norton, A. Duffy, Measured thermal \& daylight performance of an evacuated glazing using an outdoor test cell, Appl. Energy 177 (2016) 196-203, https://doi.org/10.1016/j.apenergy.2016.05.118.

[81] A. Ghosh, B. Norton, A. Duffy, Effect of sky clearness index on transmission of evacuated (vacuum) glazing, Renew. Energy 105 (2017) 160-166, https:// doi.org/10.1016/j.renene.2016.12.056.

[82] R.E. Collins, S.J. Robinson, Evacuated glazing, Sol. Energy 47 (1991) 27-38, https://doi.org/10.1016/0038-092X(91)90060-A

[83] R.E. Collins, A.C. Fischer-Cripps, J.Z. Tang, Transparent evacuated insulation, Sol. Energy 49 (1992) 333-350, https://doi.org/10.1016/0038-092X(92) 90106-K.

[84] R.E. Collins, C. a. Davis, C.J. Dey, S.J. Robinson, J.-Z. Tang, G.M. Turner, Measurement of local heat flow in flat evacuated glazing, Int. J. Heat Mass Tran. 36 (1993) 2553-2563, https://doi.org/10.1016/S0017-9310(05)80193-0.

[85] R.E. Collins, T.M. Simko, Current status of the science and technology of vacuum glazing, Sol. Energy 62 (1998) 189-213, https://doi.org/10.1016 S0038-092X(98)00007-3.

[86] P.W. Griffiths, M. Di Leo, P. Cartwright, P.C. Eames, P. Yianoulis, G. Leftheriotis, B. Norton, Fabrication of evacuated glazing at low temperature, Sol. Energy 63 (1998) 243-249, https://doi.org/10.1016/S0038092X(98)00019-X

[87] T.J. Hyde, P.W. Griffiths, P.C. Eames, B. Norton, Development of a Novel Low Temperature Edge Seal for Evacuated Glazing, (n.d.) 2-5.

[88] Y. Fang, P.C. Eames, T.J. Hyde, B. Norton, Complex multimaterial insulating frames for windows with evacuated glazing, Sol. Energy 79 (2005) 245-261, https://doi.org/10.1016/j.solener.2004.11.009.

[89] Y. Fang, P.C. Eames, B. Norton, T.J. Hyde, Experimental validation of a numerical model for heat transfer in vacuum glazing, Sol. Energy 80 (2006) 564-577, https://doi.org/10.1016/j.solener.2005.04.002.

[90] Y. Fang, P.C. Eames, B. Norton, T.J. Hyde, J. Zhao, J. Wang, Y. Huang, Low emittance coatings and the thermal performance of vacuum glazing, Sol. Energy 81 (2007) 8-12, https://doi.org/10.1016/j.solener.2006.06.011.

[91] S. Memon, P.C. Eames, Predicting the solar energy and space-heating energy performance for solid-wall detached house retrofitted with the composite edge-sealed triple vacuum glazing, Energy Procedia 122 (2017) 565-570, https://doi.org/10.1016/j.egypro.2017.07.419.

[92] S. Memon, Experimental measurement of hermetic edge seal's therma conductivity for the thermal transmittance prediction of triple vacuum glazing, Case Stud. Therm. Eng. 10 (2017) 169-178, https://doi.org/10.1016 j.csite.2017.06.002.

[93] S. Memon, F. Farukh, P.C. Eames, V.V. Silberschmidt, A new low-temperature hermetic composite edge seal for the fabrication of triple vacuum glazing Vacuum 120 (2015) 73-82, https://doi.org/10.1016/j.vacuum.2015.06.024.

[94] J. Zhao, S. Luo, X. Zhang, W. Xu, Preparation of a transparent supporting spacer array for vacuum glazing, Vacuum 93 (2013) 60-64, https://doi.org 10.1016/j.vacuum.2013.01.002.

[95] M. Lenzen, R.E. Collins, Long-term field tests of vacuum glazing, Sol. Energy 61 (1997) 11-15, https://doi.org/10.1016/S0038-092X(97)00038-8.

[96] H. Manz, S. Brunner, L. Wullschleger, Triple vacuum glazing: heat transfer and basic mechanical design constraints, Sol. Energy 80 (2006) 1632-1642 https://doi.org/10.1016/j.solener.2005.11.003.

[97] Y. Fang, T.J. Hyde, N. Hewitt, Predicted thermal performance of triple vacuum glazing, Sol. Energy 84 (2010) 2132-2139, https://doi.org/10.1016/ j.solener.2010.09.002.

[98] Y. Fang, T.J. Hyde, F. Arya, N. Hewitt, R. Wang, Y. Dai, Enhancing the thermal performance of triple vacuum glazing with low-emittance coatings, Energy Build. 97 (2015) 186-195, https://doi.org/10.1016/j.enbuild.2015.04.006.

[99] S. Kistler, Coherent expanded aerogels and jellies, Nature 127 (1931) 741 
[100] F. Ehrburger-Dolle, J. Dallamano, G.M. Pajonk, E. Elaloui, Characterization of the microporosity and surface area of silica aerogels, Stud. Surf. Sci. Catal. (1994), https://doi.org/10.1016/S0167-2991(08)63134-1.

[101] P. Wagh, G. Pajonk, H.D.,A.V. Rao, Influence of temperature on the physical properties of critic acid catalyze TEOS silica aerogels, Mater. Chem. Phys. 50 (1997) 76-81.

[102] G.M. Pajonk, Transparent silica aerogels, J. Non-Cryst. Solids (1998), https:// doi.org/10.1016/S0022-3093(98)00131-8.

[103] T. Gao, B.P. Jelle, T. Ihara, A. Gustavsen, Insulating glazing units with silica aerogel granules: the impact of particle size, Appl. Energy 128 (2014) 27-34, https://doi.org/10.1016/j.apenergy.2014.04.037.

[104] N. Husing, U. Schubert, Aerogels - airy materials: chemistry, structure and properties, Angew. Chem. Int. Ed. 2 (1998) 22-45.

[105] Y. Huang, J. lei Niu, Application of super-insulating translucent silica aerogel glazing system on commercial building envelope of humid subtropical climates - impact on space cooling load, Energy 83 (2015) 316-325, https:// doi.org/10.1016/j.energy.2015.02.027.

[106] U. Berardi, The development of a monolithic aerogel glazed window for an energy retrofitting project, Appl. Energy 154 (2015) 603-615, https:// doi.org/10.1016/j.apenergy.2015.05.059.

[107] B. Yuan, S. Ding, D. Wang, G. Wang, H. Li, Heat insulation properties of silica aerogel/glass fiber composites fabricated by press forming, Mater. Lett. 75 (2012) 204-206.

[108] C. Buratti, E. Moretti, Experimental performance evaluation of aerogel glazing systems, Appl. Energy 97 (2012) 430-437, https://doi.org/10.1016/ j.apenergy.2011.12.055.

[109] C. Buratti, E. Moretti, Glazing systems with silica aerogel for energy savings in buildings, Appl. Energy 98 (2012) 396-403, https://doi.org/10.1016/ j.apenergy.2012.03.062.

[110] C. Buratti, E. Moretti, Silica nanogel for energy-efficient windows, Nanotechnol, Eco-Efficient Constr. (2013) 207-235, https://doi.org/10.1533/ 9780857098832.2.207.

[111] J.M. Schultz, K.I. Jensen, Evacuated aerogel glazings, Vacuum 82 (2008) 723-729, https://doi.org/10.1016/j.vacuum.2007.10.019.

[112] T. Gao, T. Ihara, S. Grynning, B.P. Jelle, A.G. Lien, Perspective of aerogel glazings in energy efficient buildings, Build. Environ. 95 (2016) 405-413, https://doi.org/10.1016/j.buildenv.2015.10.001.

[113] K.I. Jensen, J.M. Schultz, F.H. Kristiansen, Development of windows based on highly insulating aerogel glazings, J. Non-Cryst. Solids 350 (2004) 351-357, https://doi.org/10.1016/j.jnoncrysol.2004.06.047.

[114] J.M. Schultz, K.I. Jensen, F.H. Kristiansen, Super insulating aerogel glazing, Sol. Energy Mater. Sol. Cells 89 (2005) 275-285, https://doi.org/10.1016/ j.solmat.2005.01.016.

[115] G.S. Kim, S.H. Hyun, Synthesis of window glazing coated with silica aeroge films via ambient drying, J. Non-Cryst. Solids 320 (2003) 125-132, https:// doi.org/10.1016/S0022-3093(03)00027-9.

[116] K. Duer, S. Svendsen, Monolithic silica aerogel in superinsulating glazings, Sol. Energy 63 (1998) 259-267, https://doi.org/10.1016/S0038-092X(98) 00063-2.

[117] M. Reim, A. Beck, W. Körner, R. Petricevic, M. Glora, M. Weth, T. Schliermann, J. Fricke, C. Schmidt, F.J. Pötter, Highly insulating aerogel glazing for solar energy usage, Sol. Energy 72 (2002) 21-29, https://doi.org/10.1016/S0038 092X(01)00086-X.

[118] M. Reim, W. Körner, J. Manara, S. Korder, M. Arduini-Schuster, H.P. Ebert, J. Fricke, Silica aerogel granulate material for thermal insulation and daylighting, Sol. Energy 79 (2005) 131-139, https://doi.org/10.1016/ j.solener.2004.08.032.

[119] M. Reim, G. Reichenauer, W. Körner, J. Manara, M. Arduini-Schuster S. Korder, A. Beck, J. Fricke, Silica-aerogel granulate - structural, optical and thermal properties, J. Non-Cryst. Solids 350 (2004) 358-363, https://doi.org/ 10.1016/j.jnoncrysol.2004.06.048.

[120] Y. Huang, J. Niu, Energy and visual performance of the silica aerogel glazing system in commercial buildings of Hong Kong, Construct. Build. Mater. 94 (2015) 57-72, https://doi.org/10.1016/j.conbuildmat.2015.06.053.

[121] L.L. Aranda, Silica Aerogel, 2001, pp. 12-15.

[122] T. Ihara, S. Grynning, T. Gao, A. Gustavsen, B.P. Jelle, Impact of convection on thermal performance of aerogel granulate glazing systems, Energy Build. 88 (2015) 165-173, https://doi.org/10.1016/j.enbuild.2014.12.001.

[123] T. Ihara, B.P. Jelle, T. Gao, A. Gustavsen, Aerogel granule aging driven by moisture and solar radiation, Energy Build. 103 (2015) 238-248, https:// doi.org/10.1016/j.enbuild.2015.06.017.

[124] T. Ihara, T. Gao, S. Grynning, B.P. Jelle, A. Gustavsen, Aerogel granulate glazing facades and their application potential from an energy saving perspective, Appl. Energy 142 (2015) 179-191, https://doi.org/10.1016/ j.apenergy.2014.12.053.

[125] P.K. Ng, N. Mithraratne, Lifetime performance of semi-transparent buildingintegrated photovoltaic (BIPV) glazing systems in the tropics, Renew. Sustain. Energy Rev. 31 (2014) 736-745, https://doi.org/10.1016/ j.rser.2013.12.044.

[126] J. Han, L. Lu, H. Yang, Thermal behavior of a novel type see-through glazing system with integrated PV cells, Build. Environ. 44 (2009) 2129-2136, https://doi.org/10.1016/j.buildenv.2009.03.003.

[127] N. Skandalos, D. Karamanis, PV glazing technologies, Renew. Sustain. Energy Rev. 49 (2015) 306-322, https://doi.org/10.1016/j.rser.2015.04.145.

[128] P.K. Ng, N. Mithraratne, H.W. Kua, Energy analysis of semi-transparent BIPV in Singapore buildings, Energy Build. 66 (2013) 274-281, https://doi.org/ 10.1016/j.enbuild.2013.07.029.

[129] B. Norton, P.C. Eames, T.K. Mallick, M.J. Huang, S.J. McCormack, J.D. Mondol, Y.G. Yohanis, Enhancing the performance of building integrated photovoltaics, Sol. Energy 85 (2011) 1629-1664, https://doi.org/10.1016/ j.solener.2009.10.004.

[130] H.M. Lee, J.H. Yoon, S.C. Kim, U.C. Shin, Operational power performance of south-facing vertical BIPV window system applied in office building, Sol. Energy 145 (2017) 66-77, https://doi.org/10.1016/j.solener.2016.07.056.

[131] W. He, Y.X. Zhang, W. Sun, J.X. Hou, Q.Y. Jiang, J. Ji, Experimental and numerical investigation on the performance of amorphous silicon photovoltaics window in East China, Build. Environ. 46 (2011) 363-369, https:// doi.org/10.1016/j.buildenv.2010.07.030.

[132] R. Charron, A.K. Athienitis, Optimization of the performance of double-façades with integrated photovoltaic panels and motorized blinds, Sol. Energy 80 (2006) 482-491, https://doi.org/10.1016/j.solener.2005.05.004.

[133] J. Khedari, J. Waewsak, W. Supheng, J. Hirunlabh, Experimental investigation of performance of a multi-purpose PV-slat window, Sol. Energy Mater. Sol. Cells 82 (2004) 431-445, https://doi.org/10.1016/j.solmat.2004.02.004.

[134] T.Y.Y. Fung, H. Yang, Study on thermal performance of semi-transparent building-integrated photovoltaic glazings, Energy Build. 40 (2008) 341-350, https://doi.org/10.1016/j.enbuild.2007.03.002.

[135] T. Miyazaki, A. Akisawa, T. Kashiwagi, Energy savings of office buildings by the use of semi-transparent solar cells for windows, Renew. Energy 30 (2005) 281-304, https://doi.org/10.1016/j.renene.2004.05.010.

[136] T.T. Chow, K.F. Fong, W. He, Z. Lin, A.L.S. Chan, Performance evaluation of a PV ventilated window applying to office building of Hong Kong, Energy Build. 39 (2007) 643-650, https://doi.org/10.1016/j.enbuild.2006.09.014.

[137] T.T. Chow, Z. Qiu, C. Li, Potential application of "see-through" solar cells in ventilated glazing in Hong Kong, Sol. Energy Mater. Sol. Cells 93 (2009) 230-238, https://doi.org/10.1016/j.solmat.2008.10.002.

[138] E. Cuce, Toward multi-functional PV glazing technologies in low/zero carbon buildings: heat insulation solar glass - latest developments and future prospects, Renew. Sustain. Energy Rev. 60 (2016) 1286-1301, https:// doi.org/10.1016/j.rser.2016.03.009.

[139] E. Cuce, C.-H. Young, S.B. Riffat, Thermal performance investigation of heat insulation solar glass: a comparative experimental study, Energy Build. 86 (2015) 595-600, https://doi.org/10.1016/j.enbuild.2014.10.063.

[140] C.-H. Young, Y.-L. Chen, P.-C. Chen, Heat insulation solar glass and application on energy efficiency buildings, Energy Build. 78 (2014) 66-78, https:// doi.org/10.1016/j.enbuild.2014.04.012.

[141] M. Morini, R. Corrao, Energy optimization of BIPV glass blocks: a multisoftware study, Energy Procedia 111 (2017) 982-992, https://doi.org/ 10.1016/j.egypro.2017.03.261.

[142] O. Bouvard, S. Vanzo, A. Schüler, Experimental determination of optical and thermal properties of semi-transparent photovoltaic modules based on dyesensitized solar cells, Energy Procedia 78 (2015) 453-458, https://doi.org/ 10.1016/j.egypro.2015.11.696.

[143] J.W. Lee, J. Park, H.J. Jung, A feasibility study on a building's window system based on dye-sensitized solar cells, Energy Build. 81 (2014) 38-47, https:// doi.org/10.1016/j.enbuild.2014.06.010.

[144] J.G. Kang, J.H. Kim, J.T. Kim, Performance evaluation of DSC windows for buildings, Int. J. Photoenergy 2013 (2013), https://doi.org/10.1155/2013/ 472086.

[145] S. Yoon, S. Tak, J. Kim, Y. Jun, K. Kang, J. Park, Application of transparent dyesensitized solar cells to building integrated photovoltaic systems, Build. Environ. $46 \quad$ (2011) 1899-1904, https://doi.org/10.1016/ j.buildenv.2011.03.010.

[146] M.G. Kang, N.G. Park, Y.J. Park, K.S. Ryu, S.H. Chang, Manufacturing method for transparent electric windows using dye-sensitized $\mathrm{TiO} 2$ solar cells, Sol. Energy Mater. Sol. Cells 75 (2003) 475-479, https://doi.org/10.1016/S09270248(02)00202-7.

[147] A. Cannavale, L. Ierardi, M. Hörantner, G.E. Eperon, H.J. Snaith, U. Ayr, F. Martellotta, Improving energy and visual performance in offices using building integrated perovskite-based solar cells: a case study in Southern Italy, Appl. Energy 205 (2017) 834-846, https://doi.org/10.1016/ j.apenergy.2017.08.112.

[148] A. Cannavale, M. Hörantner, G.E. Eperon, H.J. Snaith, F. Fiorito, U. Ayr, F. Martellotta, Building integration of semitransparent perovskite-based solar cells: energy performance and visual comfort assessment, Appl. Energy 194 (2017) 94-107, https://doi.org/10.1016/j.apenergy.2017.03.011.

[149] M.I. Asghar, J. Zhang, H. Wang, P.D. Lund, Device stability of perovskite solar cells - a review, Renew. Sustain. Energy Rev. 77 (2017) 131-146, https:// doi.org/10.1016/j.rser.2017.04.003.

[150] U. Mehmood, A. Al-Ahmed, F.A. Al-Sulaiman, M.I. Malik, F. Shehzad, A.U.H. Khan, Effect of temperature on the photovoltaic performance and stability of solid-state dye-sensitized solar cells: a review, Renew. Sustain. Energy Rev. 79 (2017) 946-959, https://doi.org/10.1016/j.rser.2017.05.114.

[151] S. Barman, A. Chowdhury, S. Mathur, J. Mathur, Assessment of the efficiency of window integrated CdTe based semi-transparent photovoltaic module, Sustain. Cities Soc. 37 (2018) 250-262, https://doi.org/10.1016/ j.scs.2017.09.036.

[152] M.J. Sorgato, K. Schneider, R. Rüther, Technical and economic evaluation of thin-film CdTe building-integrated photovoltaics (BIPV) replacing façade and rooftop materials in office buildings in a warm and sunny climate, Renew. 
Energy 118 (2018) 84-98, https://doi.org/10.1016/j.renene.2017.10.091.

[153] A. Ghosh, P. Selvaraj, S. Sundaram, T.K. Mallick, The colour rendering index and correlated colour temperature of dye-sensitized solar cell for adaptive glazing application, Sol. Energy 163 (2018) 537-544, https://doi.org/ 10.1016/j.solener.2018.02.021.

[154] H. Ye, X. Meng, B. Xu, Theoretical discussions of perfect window, ideal near infrared solar spectrum regulating window and current thermochromic window, Energy Build. 49 (2012) 164-172, https://doi.org/10.1016/ j.enbuild.2012.02.011.

[155] H. Ye, L. Long, H. Zhang, B. Xu, Y. Gao, L. Kang, Z. Chen, The demonstration and simulation of the application performance of the vanadium dioxide single glazing, Sol. Energy Mater. Sol. Cells 117 (2013) 168-173, https:// doi.org/10.1016/j.solmat.2013.05.061.

[156] L. Long, H. Ye, Discussion of the performance improvement of thermochromic smart glazing applied in passive buildings, Sol. Energy 107 (2014) 236-244, https://doi.org/10.1016/j.solener.2014.05.014.

[157] M. Saeli, C. Piccirillo, I.P. Parkin, R. Binions, I. Ridley, Energy modelling studies of thermochromic glazing, Energy Build. 42 (2010) 1666-1673, https://doi.org/10.1016/j.enbuild.2010.04.010.

[158] F. Morin, Oxides which show a metal to insulator transition at the neel temperature, Phys. Rev. Lett. 3 (1959) 34-36.

[159] N. Wang, S. Magdassi, D. Mandler, Y. Long, Simple sol-gel process and onestep annealing of vanadium dioxide thin films: synthesis and thermochromic properties, Thin Solid Films 534 (2013) 594-598, https://doi.org/ 10.1016/j.tsf.2013.01.074.

[160] S. Zheng, Y. Xu, Q. Shen, H. Yang, Preparation of thermochromic coatings and their energy saving analysis, Sol. Energy 112 (2015) 263-271, https:// doi.org/10.1016/j.solener.2014.09.049.

[161] E.S. Lee, X. Pang, S. Hoffmann, H. Goudey, A. Thanachareonkit, An empirical study of a full-scale polymer thermochromic window and its implications on material science development objectives, Sol. Energy Mater. Sol. Cells 116 (2013) 14-26, https://doi.org/10.1016/j.solmat.2013.03.043.

[162] Z. Huang, S. Chen, B. Wang, Y. Huang, N. Liu, J. Xu, J. Lai, Vanadium dioxide thin film with low phase transition temperature deposited on borosilicate glass substrate, Thin Solid Films 519 (2011) 4246-4248, https://doi.org/ 10.1016/j.tsf.2011.01.394.

[163] M.H. Lee, Thermochromic glazing of windows with better luminous solar transmittance, Sol. Energy Mater. Sol. Cells 71 (2002) 537-540, https:// doi.org/10.1016/S0927-0248(01)00135-0.

[164] S.Y. Li, G.A. Niklasson, C.G. Granqvist, Nanothermochromics: calculations for VO2 nanoparticles in dielectric hosts show much improved luminous transmittance and solar energy transmittance modulation, J. Appl. Phys. 108 (2010) 1-8, https://doi.org/10.1063/1.3487980.

[165] M. Saeli, C. Piccirillo, I.P. Parkin, I. Ridley, R. Binions, Nano-composite thermochromic thin films and their application in energy-efficient glazing, Sol. Energy Mater. Sol. Cells 94 (2010) 141-151, https://doi.org/10.1016/ j.solmat.2009.08.010.

[166] L. Long, H. Ye, H. Zhang, Y. Gao, Performance demonstration and simulation of thermochromic double glazing in building applications, Sol. Energy 120 (2015) 55-64, https://doi.org/10.1016/j.solener.2015.07.025

[167] L. Long, H. Ye, Performance demonstration and evaluation of the synergetic application of thermochromic window and phase change material in passive buildings, Energy Procedia 61 (2014) 941-944, https://doi.org/10.1016/ j.egypro.2014.11.1000.

[168] S. Hoffmann, E.S. Lee, C. Clavero, Examination of the technical potential of near-infrared switching thermochromic windows for commercial building applications, Sol. Energy Mater. Sol. Cells 123 (2014) 65-80, https://doi.org/ 10.1016/j.solmat.2013.12.017.

[169] L. Long, H. Ye, Dual-intelligent windows regulating both solar and long-wave radiations dynamically, Sol. Energy Mater. Sol. Cells 169 (2017) 145-150, https://doi.org/10.1016/j.solmat.2017.05.022.

[170] C.G. Granqvist, Recent progress in thermochromics and electrochromics: a brief survey, Thin Solid Films 614 (2015) 90-96, https://doi.org/10.1016/ j.tsf.2016.02.029.

[171] P. Nitz, H. Hartwig, Solar control with thermotropic layers, Sol. Energy 79 (2005) 573-582, https://doi.org/10.1016/j.solener.2004.12.009.

[172] H. Watanabe, Intelligent window using a hydrogel layer for energy efficiency, Sol. Energy Mater. Sol. Cells 54 (1998) 203-211, https://doi.org/ 10.1016/S0927-0248(98)00072-5.

[173] A. Raicu, H.R. Wilson, P. Nitz, W. Platzer, V. Wittwer, E. Jahns, Facade systems with variable solar control using thermotropic polymer blends, Sol. Energy 72 (2002) 31-42, https://doi.org/10.1016/S0038-092X(01)00093-7.

[174] A.C. Gladen, J.H. Davidson, S.C. Mantell, Selection of thermotropic materials for overheat protection of polymer absorbers, Sol. Energy 104 (2014) 42-51, https://doi.org/10.1016/j.solener.2013.10.026.

[175] K. Allen, K. Connelly, P. Rutherford, Y. Wu, Smart windows-dynamic control of building energy performance, Energy Build. 139 (2017) 535-546, https:// doi.org/10.1016/j.enbuild.2016.12.093.

[176] J. Yao, N. Zhu, Evaluation of indoor thermal environmental, energy and daylighting performance of thermotropic windows, Build. Environ. 49 (2012) 283-290, https://doi.org/10.1016/j.buildenv.2011.06.004.

[177] L. Bianco, F. Goia, V. Serra, M. Zinzi, Thermal and optical properties of a thermotropic glass pane: laboratory and in-field characterization, Energy Procedia 78 (2015) 116-121, https://doi.org/10.1016/j.egypro.2015.11.124.

[178] D. Kim, E. Lee, H.S. Lee, J. Yoon, Energy efficient glazing for adaptive solar control fabricated with photothermotropic hydrogels containing graphene oxide, Sci. Rep. 5 (2015) 7646, https://doi.org/10.1038/srep07646.

[179] T. Fischer, R. Lange, A. Seeboth, Hybrid solar and electrically controlled transmission of light filters, Sol. Energy Mater. Sol. Cells 64 (2000) 321-331 https://doi.org/10.1016/S0927-0248(00)00217-8.

[180] R. Baetens, B.P. Jelle, A. Gustavsen, Phase change materials for building applications: a state-of-the-art review, Energy Build. 42 (2010) 1361-1368, https://doi.org/10.1016/j.enbuild.2010.03.026.

[181] X. Jin, M.A. Medina, X Zhang On the importance of the location of PCMs in building walls for enhanced thermal performance, Appl. Energy 106 (2013) 72-78, https://doi.org/10.1016/j.apenergy.2012.12.079.

[182] K. Pielichowska, K. Pielichowski, Phase change materials for thermal energy storage, Prog. Mater. Sci. 65 (2014) 67-123, https://doi.org/10.1016 j.pmatsci.2014.03.005

[183] K.A.R. Ismail, J.R. Henríquez, Parametric study on composite and PCM glass systems, Energy Convers. Manag. 43 (2002) 973-993, https://doi.org 10.1016/S0196-8904(01)00083-8.

[184] K.A.R. Ismail, C.T. Salinas, J.R. Henriquez, Comparison between PCM filled glass windows and absorbing gas filled windows, Energy Build. 40 (2008) 710-719, https://doi.org/10.1016/j.enbuild.2007.05.005.

[185] H. Weinläder, A. Beck, J. Fricke, PCM-facade-panel for daylighting and room heating, Sol. Energy 78 (2005) 177-186, https://doi.org/10.1016/ j.solener 2004.04.013.

[186] F. Goia, Thermo-physical behaviour and energy performance assessment of PCM glazing system configurations: a numerical analysis, Front. Archit. Res. 1 (2012) 341-347, https://doi.org/10.1016/j.foar.2012.10.002.

[187] F. Goia, M. Perino, V. Serra, Improving thermal comfort conditions by means of PCM glazing systems, Energy Build. 60 (2013) 442-452, https://doi.org/ 10.1016/j.enbuild.2013.01.029.

[188] F. Goia, M. Perino, V. Serra, Experimental analysis of the energy performance of a full-scale PCM glazing prototype, Sol. Energy 100 (2014) 217-233, https://doi.org/10.1016/j.solener.2013.12.002.

[189] L. Diaz, R. Viskanta, Experiments and analysis on the melting of a semitransparent material by radiation, Wärme- Und Stoffübertragung 20 (1986) 311-321.

[190] F. Goia, M. Perino, M. Haase, A numerical model to evaluate the therma behaviour of PCM glazing system configurations, Energy Build. 54 (2012) 141-153, https://doi.org/10.1016/j.enbuild.2012.07.036.

[191] F. Goia, M. Zinzi, E. Carnielo, V. Serra, Spectral and angular solar properties of a PCM-filled double glazing unit, Energy Build. 87 (2015) 302-312, https:// doi.org/10.1016/j.enbuild.2014.11.019.

[192] F. Goia, M. Zinzi, E. Carnielo, V. Serra, Characterization of the optical properties of a PCM glazing system, Energy Procedia 30 (2012) 428-437, https:// doi.org/10.1016/j.egypro.2012.11.051.

[193] H. Manz, P.W. Egolf, P. Suter, A. Goetzberger, TIM-PCM external wall system for solar space heating and daylighting, Sol. Energy 61 (1997) 369-379, https://doi.org/10.1016/S0038-092X(97)00086-8.

194] S. Li, K. Zhong, Y. Zhou, X. Zhang, Dynamic heat transfer characteristics of PCM-filled glass window and hollow glass window, Energy Build. 85 (2014) 483-492, https://doi.org/10.3969/j.issn.0438-1157.2014.z2.018.

195] F. Goia, E. Boccaleri, Physical-chemical properties evolution and therma properties reliability of a paraffin wax under solar radiation exposure in a real-scale PCM window system, Energy Build. 119 (2016) 41-50, https:// doi.org/10.1016/j.enbuild.2016.03.007.

[196] A. Georg, W. Graf, R. Neumann, V. Wittwer, Stability of gasochromic WO3 films, Sol. Energy Mater. Sol. Cells 63 (2000) 165-176, https://doi.org/ 10.1016/S0927-0248(00)00006-4.

197] A. Georg, W. Graf, R. Neumann, V. Wittwer, Mechanism of the gasochromic coloration of porous WO3 films, Solid State Ionics 127 (2000) 319-328, https://doi.org/10.1016/S0167-2738(99)00273-8.

[198] A.U. Georg, W. Graf, R. Neumann, V. Wittwer, The Role of Water in Gasochromic WO 3 Films, 2001, pp. 269-275.

[199] V. Wittwer, M. Datz, J. Ell, A. Georg, W. Graf, G. Walze, Gasochromic windows, Sol. Energy Mater. Sol. Cells 84 (2004) 305-314, https://doi.org/ 10.1016/j.solmat 2004.01.040.

[200] L. Zhuang, X. Xu, H. Shen, A study on the gasochromic properties of WO3 thin films, Surf, Coat. Technol. 167 (2003) 217-220, https://doi.org/10.1016/ S0257-8972(02)00904-0.

[201] D. Schweiger, A. Georg, W. Graf, V. Wittwer, Examination of the kinetics and performance of a catalytically switching (gasochromic) device, Sol. Energy Mater. Sol. Cells 54 (1998) 99-108, https://doi.org/10.1016/S0927-0248(98) 00060-9.

[202] S.J. Ippolito, S. Kandasamy, K. Kalantar-Zadeh, W. Wlodarski, Hydrogen sensing characteristics of WO3 thin film conductometric sensors activated by Pt and Au catalysts, Sensor. Actuator. B Chem. 108 (2005) 154-158, https://doi.org/10.1016/j.snb.2004.11.092.

[203] H. Shanak, H. Schmitt, J. Nowoczin, C. Ziebert, Effect of Pt-catalyst on gasochromic WO3 films: optical, electrical and AFM investigations, Solid State Ionics 171 (2004) 99-106, https://doi.org/10.1016/j.ssi.2004.04.001.

[204] M. Stolze, D. Gogova, L.K. Thomas, Analogy for the maximum obtainable colouration between electrochromic, gasochromic, and electrocolouration in DC-sputtered thin WO3-y films, Thin Solid Films 476 (2005) 185-189, https://doi.org/10.1016/j.tsf.2004.09.034.

[205] K.J. Stevenson, J.T. Huppz, Microvisualization of structural features and ion electroinsertion behavior of patterned WO3 thin films via integrated optical 
and atomic force microscopies, Electrochem. Solid State Lett. 2 (1999) 497-500, https://doi.org/10.1149/1.1390882.

[206] Y.S. Krasnov, G.Y. Kolbasov, Electrochromism and reversible changes in the position of fundamental absorption edge in cathodically deposited amorphous WO3, Electrochim. Acta 49 (2004) 2425-2433, https://doi.org/ 10.1016/j.electacta.2004.01.020.

[207] M. Zayat, R. Reisfeld, H. Minti, B. Orel, F. Svegl, Gasochromic effect in platinum-doped tungsten trioxide films prepared by the sol-gel method, J. Sol. Gel Sci. Technol. 11 (1998) 161-168, https://doi.org/10.1023/A: 1008645530803.

[208] B. Orel, U. Opara Krašovec, N. Grošelj, M. Kosec, G. Dražič, R. Reisfeld, Gasochromic behavior of sol-gel derived Pd doped peroxopolytungstic acid (W-PTA) nano-composite films, J. Sol. Gel Sci. Technol. 14 (1999) 291-308, https://doi.org/10.1023/A:1008773614398.

[209] W. Feng, G. Wu, G. Gao, Supporting Information for Ordered Mesoporous WO 3 Film with Outstanding Gasochromic Properties, 2013, pp. 0-4.

[210] G. Gao, J. Wu, G. Wu, Z. Zhang, W. Feng, J. Shen, B. Zhou, Phase transition effect on durability of WO 3 hydrogen sensing films: an insight by experiment and first-principle method, Sensor. Actuator. B Chem. 171-172 (2012) 1288-1291, https://doi.org/10.1016/j.snb.2012.06.028.

[211] J. Shi, G. Hu, Y. Sun, M. Geng, J. Wu, Y. Liu, M. Ge, J. Tao, M. Cao, N. Dai, WO3 nanocrystals: synthesis and application in highly sensitive detection of acetone, Sensor. Actuator. B Chem. 156 (2011) 820-824, https://doi.org/ 10.1016/j.snb.2011.02.047.

[212] W. Feng, L. Zou, G. Gao, G. Wu, J. Shen, W. Li, Gasochromic smart window: optical and thermal properties, energy simulation and feasibility analysis, Sol. Energy Mater. Sol. Cells 144 (2016) 316-323, https://doi.org/10.1016/ j.solmat.2015.09.029.

[213] C.G. Granqvist, Handbook of Inorganic Electrochromic Materials, 1995.

[214] A. Georg, W. Graf, D. Schweiger, V. Wittwer, P. Nitz, H.R. Wilson, Switchable glazing with a large dynamic range in total solar energy transmittance (TSET), Sol. Energy 62 (1998) 215-228, https://doi.org/10.1016/S0038092X(98)00014-0.

[215] K. Yoshimura, Y. Yamada, S. Bao, K. Tajima, M. Okada, Preparation and characterization of gasochromic switchable-mirror window with practical size, Sol. Energy Mater. Sol. Cells 93 (2009) 2138-2142, https://doi.org/ 10.1016/j.solmat.2009.03.023.

[216] C.-C. Chan, W.-C. Hsu, C.-C. Chang, C.-S. Hsu, Preparation and characterization of gasochromic Pt/WO3 hydrogen sensor by using the Taguchi design method, Sensor. Actuator. B Chem. 145 (2010) 691-697, https://doi.org/ 10.1016/j.snb.2010.01.021.

[217] Y.X. Ji, S.Y. Li, G.A. Niklasson, C.G. Granqvist, Durability of thermochromic VO2thin films under heating and humidity: effect of Al oxide top coatings, Thin Solid Films 562 (2014) 568-573, https://doi.org/10.1016/ j.tsf.2014.03.043.

[218] C.G. Granqvist, Electrochromics for smart windows: oxide-based thin fi lms and devices, Thin Solid Films 564 (2014) 1-38, https://doi.org/10.1016/ j.tsf.2014.02.002

[219] C.G. Granqvist, Electrochromic devices, J. Eur. Ceram. Soc. 25 (2005) 2907-2912, https://doi.org/10.1016/j.jeurceramsoc.2005.03.162.

[220] G. Macrelli, Electrochromic windows, Renew. Energy 15 (1998) 306-311, https://doi.org/10.1016/S0960-1481(98)00178-5.

[221] C.M. Lampert, Electrochromic materials and devices for energy efficient windows, Sol. Energy Mater. 11 (1984) 1-27, https://doi.org/10.1016/01651633(84)90024-8.

[222] R.J. Mortimer, Organic electrochromic materials, Electrochim. Acta 44 (1999) 2971-2981, https://doi.org/10.1016/S0013-4686(99)00046-8.

[223] R.J. Mortimer, A.L. Dyer, J.R. Reynolds, Electrochromic organic and polymeric materials for display applications, Displays 27 (2006) 2-18, https://doi.org/ 10.1016/j.displa.2005.03.003.

[224] C. Lampert, Smart switchable glazing for solar energy and daylight control, Sol. Energy Mater. Sol. Cells 52 (1998) 207-221, https://doi.org/10.1016/ S0927-0248(97)00279-1.

[225] Y. Ji, C. Qin, H. Niu, L. Sun, Z. Jin, X. Bai, Electrochemical and electrochromic behaviors of polyaniline-graphene oxide composites on the glass substrate Ag nano-film electrodes prepared by vertical target pulsed laser deposition, Dye. Pigment 117 (2015) 72-82, https://doi.org/10.1016/ j.dyepig.2015.01.026.

[226] X. Fu, C. Jia, Z. Wan, X. Weng, J. Xie, L. Deng, Hybrid electrochromic film based on polyaniline and TiO2 nanorods array, Org. Electron. Physics, Mater. Appl. 15 (2014) 2702-2709, https://doi.org/10.1016/j.orgel.2014.07.040.

[227] C. Xu, L. Liu, S.E. Legenski, D. Ning, M. Taya, Switchable window based on electrochromic polymers, J. Mater. Res. 19 (2004) 2072-2080, https:/ doi.org/10.1557/JMR.2004.0259.

[228] T. Kubo, T. Shinada, Y. Kobayashi, H. Imafuku, T. Toya, S. Akita, Y. Nishikitani, $\mathrm{H}$. Watanabe, Current state of the art for NOC-AGC electrochromic windows for architectural and automotive applications, Solid State Ionics 165 (2003) 209-216, https://doi.org/10.1016/j.ssi.2003.08.043.

[229] C.G. Granqvist, Progress in electrochromics: tungsten oxide revisited, Elec trochim. Acta 44 (1999) 3005-3015, https://doi.org/10.1016/S00134686(99)00016-X

[230] C.G. Granqvist, A. Azens, P. Heszler, L.B. Kish, L. Österlund, Nanomaterials for benign indoor environments: electrochromics for "smart windows", sensors for air quality, and photo-catalysts for air cleaning, Sol. Energy Mater. Sol. Cells 91 (2007) 355-365, https://doi.org/10.1016/j.solmat.2006.10.011.
[231] C.G. Granqvist, Electrochromic oxides: a bandstructure approach, Sol. Energy Mater. Sol. Cells 32 (1994) 369-382, https://doi.org/10.1016/0927-0248(94) 90100-7.

[232] C.G. Granqvist, Electrochromic oxides: a unified view, Solid State Ionics 70-71 (1994) 678-685, https://doi.org/10.1016/0167-2738(94)90393-X.

[233] S. Papaefthimiou, E. Syrrakou, P. Yianoulis, An alternative approach for the energy and environmental rating of advanced glazing: an electrochromic window case study, Energy Build. 41 (2009) 17-26, https://doi.org/10.1016/ j.enbuild.2008.07.008.

[234] S.K. Deb, S.H. Lee, C. Edwin Tracy, J. Roland Pitts, B.A. Gregg, H.M. Branz, Stand-alone photovoltaic-powered electrochromic smart window, Electrochim. Acta 46 (2001) 2125-2130, https://doi.org/10.1016/S0013-4686(01) 00390-5.

[235] J. Nagai, G.D. McMeeking, Y. Saitoh, Durability of electrochromic glazing, Sol. Energy Mater. Sol. Cells 56 (1999) 309-319, https://doi.org/10.1016/S09270248(98)00140-8.

[236] S.K. Deb, Reminiscences on the discovery of electrochromic phenomena in transition metal oxides, Sol. Energy Mater. Sol. Cells 39 (1995) 191-201, https://doi.org/10.1016/0927-0248(95)00055-0.

[237] A.M. Andersson, C.G. Granqvist, J.R. Stevens, in: Electrochromic LiWO 3/ poymer Laminate/LiyV 205 Device: toward an All-solid-state Smart Window, vol. 28, 1989, pp. 3295-3302.

[238] N. Sbar, M. Badding, R. Budziak, K. Cortez, L. Laby, L. Michalski, T. Ngo, S. Schulz, K. Urbanik, Progress toward durable, cost effective electrochromic window glazings, Sol. Energy Mater. Sol. Cells 56 (1999) 321-341, https:// doi.org/10.1016/S0927-0248(98)00141-X.

[239] N.L. Sbar, L. Podbelski, H.M. Yang, B. Pease, Electrochromic dynamic windows for office buildings, Int. J. Sustain. Built Environ. 1 (2012) 125-139, https:// doi.org/10.1016/j.ijsbe.2012.09.001.

[240] M. Zinzi, Office worker preferences of electrochromic windows: a pilot study, Build. Environ. 41 (2006) 1262-1273, https://doi.org/10.1016/ j.buildenv.2005.05.010.

[241] A. Kraft, M. Rottmann, Properties, performance and current status of the laminated electrochromic glass of Gesimat, Sol. Energy Mater. Sol. Cells 93 (2009) 2088-2092, https://doi.org/10.1016/j.solmat.2009.05.010.

[242] A. Kraft, M. Rottmann, H.D. Gilsing, H. Faltz, Electrodeposition and electrochromic properties of N-ethyl substituted poly(3,4-ethylenedioxypyrrole), Electrochim. Acta 52 (2007) 5856-5862, https://doi.org/10.1016/ j.electacta.2007.03.012.

[243] A. Kraft, M. Rottmann, K.H. Heckner, Large-area electrochromic glazing with ion-conducting PVB interlayer and two complementary electrodeposited electrochromic layers, Sol. Energy Mater. Sol. Cells 90 (2006) 469-476, https://doi.org/10.1016/j.solmat.2005.01.019.

[244] C.G. Granqvist, E. Avendaño, A. Azens, Electrochromic coatings and devices: survey of some recent advances, Thin Solid Films 442 (2003) 201-211, https://doi.org/10.1016/S0040-6090(03)00983-0.

[245] A. Azens, E. Avendaño, J. Backholm, L. Berggren, G. Gustavsson, R. Karmhag, G.A. Niklasson, A. Roos, G.G. Granqvist, Flexible foils with electrochromic coatings: science, technology and applications, Mater. Sci. Eng. B Solid-State Mater. Adv. Technol. 119 (2005) 214-223, https://doi.org/10.1016/ j.mseb.2004.12.085.

[246] A. Azens, G. Gustavsson, R. Karmhag, C.G. Granqvist, Electrochromic devices on polyester foil, Solid State Ionics 165 (2003) 1-5, https://doi.org/10.1016/ j.ssi.2003.08.009.

[247] C.G. Granqvist, Electrochromic tungsten oxide films: review of progress 1993-1998, Sol. Energy Mater. Sol. Cells 60 (2000) 201-262, https://doi.org/ 10.1016/S0927-0248(99)00088-4.

[248] J. Klems, Net energy performance measurements on electrochromic skylights, Energy Build. 33 (2001) 93-102, https://doi.org/10.1016/S03787788(00)00069-4.

[249] R.B. Goldner, ELECTROCHROMIC MATERIALS for CONTROLLED RADIANT Passive Use of Solar Radiation Could Be Automated in Buildings. Based on Our Own Results and Published Work on EC Materials, a One Square Meter Window Would Require an Energy Input of -0.2 W H/M 2 to, 11, 1984, pp. 177-185.

[250] R.D. Rauh, Electrochromic windows: an overview, Electrochim. Acta 44 (1999) 3165-3176, https://doi.org/10.1016/S0013-4686(99)00034-1.

[251] M.R. Rosseinsky DR, Electrochromic systems and the prospects for devices, Adv. Mater 13 (2001) 783-793.

[252] C.G. Granqvist, Oxide electrochromics: an introduction to devices and materials, Sol. Energy Mater. Sol. Cells 99 (2012) 1-13, https://doi.org/10.1016/ j.solmat.2011.08.021.

[253] E.S. Lee, D.L. DiBartolomeo, F.M. Rubinstein, S.E. Selkowitz, Low-cost networking for dynamic window systems, Energy Build. 36 (2004) 503-513, https://doi.org/10.1016/j.enbuild.2003.12.008.

[254] J.D. Engfeldt, P. Georen, C. Lagergren, G. Lindbergh, Methodology for measuring current distribution effects in electrochromic smart windows, Appl. Optic. 50 (2011) 5639, https://doi.org/10.1364/AO.50.005639.

[255] E.S. Lee, D.L. DiBartolomeo, Application issues for large-area electrochromic windows in commercial buildings, Sol. Energy Mater. Sol. Cells 71 (2002) 465-491, https://doi.org/10.1016/S0927-0248(01)00101-5.

[256] J.Y. Wang, C.M. Yu, S.C. Hwang, K.C. Ho, L.C. Chen, Influence of coloring voltage on the optical performance and cycling stability of a polyanilineindium hexacyanoferrate electrochromic system, Sol. Energy Mater. Sol. Cells 92 (2008) 112-119, https://doi.org/10.1016/j.solmat.2007.02.028. 
[257] C.M. Lampert, A. Agrawal, C. Baertlien, J. Nagai, Durability evaluation of electrochromic devices - an industry perspective, Sol. Energy Mater. Sol. Cells 56 (1999) 449-463, https://doi.org/10.1016/S0927-0248(98)00185-8.

[258] K.H. Heckner, A. Kraft, Similarities between electrochromic windows and thin film batteries, Solid State Ionics 152-153 (2002) 899-905, https:// doi.org/10.1016/S0167-2738(02)00446-0.

[259] C.G. Granqvist, S. Green, G.A. Niklasson, N.R. Mlyuka, S. von Kræmer, P. Georén, Advances in chromogenic materials and devices, Thin Solid Films 518 (2010) 3046-3053, https://doi.org/10.1016/j.tsf.2009.08.058.

[260] C.G. Granqvist, I. Bayrak Pehlivan, G.A. Niklasson, Electrochromics on a roll: web-coating and lamination for smart windows, Surf. Coat. Technol. (2017) 6-11, https://doi.org/10.1016/j.surfcoat.2017.08.006.

[262] N. DeForest, A. Shehabi, G. Garcia, J. Greenblatt, E. Masanet, E.S. Lee, S. Selkowitz, D.J. Milliron, Regional performance targets for transparent near-infrared switching electrochromic window glazings, Build. Environ. 61 (2013) 160-168, https://doi.org/10.1016/j.buildenv.2012.12.004.

[263] A. Georg, A. Georg, Electrochromic device with a redox electrolyte, Sol. Energy Mater. Sol. Cells 93 (2009) 1329-1337, https://doi.org/10.1016/ j.solmat.2009.02.009.

[264] F. Aleo, A. Pennisi, S. Scalia, F. Simone, Optical and energetic performances of an electrochromic window tested in a "PASSYS" cell, Electrochim. Acta 46 (2001) 2243-2249, https://doi.org/10.1016/S0013-4686(01)00367-X.

[265] P.V. Ashrit, F.E. Girouard, V.V. Truong, Fabrication and testing of an all-solid state system for smart window application, Solid State Ionics 89 (1996) 65-73, https://doi.org/10.1016/0167-2738(96)00264-0.

[266] N. DeForest, A. Shehabi, J. O'Donnell, G. Garcia, J. Greenblatt, E.S. Lee S. Selkowitz, D.J. Milliron, United States energy and CO2savings potential from deployment of near-infrared electrochromic window glazings, Build. Environ. $89 \quad$ (2015) 107-117, https://doi.org/10.1016/ j.buildenv.2015.02.021.

[267] L.L. Fernandes, E.S. Lee, G. Ward, Lighting energy savings potential of splitpane electrochromic windows controlled for daylighting with visual comfort, Energy Build. 61 (2013) 8-20, https://doi.org/10.1016/ j.enbuild.2012.10.057.

[268] E.S. Lee, D.L. Dibartolomeo, S.E. Selkowitz, Daylighting control performance of a thin-film ceramic electrochromic window: field study results, Energy Build. 38 (2006) 30-44, https://doi.org/10.1016/j.enbuild.2005.02.009.

[269] M. Moeck, Visual quality assessment of electrochromic and conventional glazings, Sol. Energy Mater. Sol. Cells 54 (1998) 157-164, https://doi.org/ 10.1016/S0927-0248(98)00066-X.

[270] A. Piccolo, Thermal performance of an electrochromic smart window tested in an environmental test cell, Energy Build. 42 (2010) 1409-1417, https:// doi.org/10.1016/j.enbuild.2010.03.010.

[271] A. Piccolo, A. Pennisi, F. Simone, Daylighting performance of an electrochromic window in a small scale test-cell, Sol. Energy 83 (2009) 832-844, https://doi.org/10.1016/j.solener.2008.11.013.

[272] A. Piccolo, F. Simone, Effect of switchable glazing on discomfort glare from windows, Build. Environ. 44 (2009) 1171-1180, https://doi.org/10.1016/ j.buildenv.2008.08.013.

[273] M.A. Arvizu, R.T. Wen, D. Primetzhofer, J.E. Klemberg-Sapieha, L. Martinu, G.A. Niklasson, C.G. Granqvist, Galvanostatic ion detrapping rejuvenates oxide thin films, ACS Appl. Mater. Interfaces 7 (2015) 26387-26390, https:// doi.org/10.1021/acsami.5b09430.

[274] R.-T. Wen, C.G. Granqvist, G.A. Niklasson, Eliminating degradation and uncovering ion-trapping dynamics in electrochromic WO3 thin films, Nat. Mater. 14 (2015) 996-1001, https://doi.org/10.1038/nmat4368.

[275] R.T. Wen, G.A. Niklasson, C.G. Granqvist, Sustainable rejuvenation of electrochromic WO3 films, ACS Appl. Mater. Interfaces 7 (2015) 28100-28104, https://doi.org/10.1021/acsami.5b09035.

[276] A. Ghosh, B. Norton, A. Duffy, Calculation of colouration voltage for a multifunctional glazing powered by photovoltaic, Conf. Pap. (2013) 3434-3436. http://arrow.dit.ie/engschcivcon/66.

[277] J.M. Bell, J.P. Matthews, Temperature dependence of kinetic behaviour of solgel deposited electrochromics, Sol. Energy Mater. Sol. Cells 68 (2001) 249-263, https://doi.org/10.1016/S0927-0248(00)00360-3.

[278] J.M. Bell, J.P. Matthews, I.L. Skryabin, Modelling switching of electrochromic devices - a route to successful large area device design, Solid State Ionics 152-153 (2002) 853-860, https://doi.org/10.1016/S0167-2738(02)00385-5.

[279] J.M. Bell, I.L. Skryabin, Failure modes of sol-gel deposited electrochromic devices, Sol. Energy Mater. Sol. Cells 56 (1999) 437-448, https://doi.org/ 10.1016/S0927-0248(98)00184-6.

[280] J.P. Matthews, J.M. Bell, I.L. Skryabin, Simulation of electrochromic switching voltages at elevated temperatures, Electrochim. Acta 46 (2001) 1957-1961, https://doi.org/10.1016/S0013-4686(01)00386-3.

[281] J.P. Matthews, J.M. Bell, I.L. Skryabin, Effect of temperature on electrochromic device switching voltages, Electrochim. Acta 44 (1999) 3245-3250, https:// doi.org/10.1016/S0013-4686(99)00043-2.

[282] J. Nagai, G.D. McMeeking, Modeling of electrochromic processes, Electrochim. Acta 44 (1999) 3177-3184, https://doi.org/10.1016/S0013-4686(99) 00035-3.

[283] No Title, (n.d.). https://www.sageglass.com/en/products.

[284] A. Ghosh, B. Norton, Durability of switching behaviour after outdoor exposure for a suspended particle device switchable glazing, Sol. Energy Mater. Sol. Cells 163 (2017) 178-184, https://doi.org/10.1016/j.solmat.2017.01.036.

[285] A. Ghosh, Dublin Institute of Technology, No Title, 2016, https://doi.org/
10.21427/D7P31T

286] A. Ghosh, B. Norton, A. Duffy, Measured overall heat transfer coefficient of suspended particle device switchable glazing, Appl. Energy 159 (2015) 362-369, https://doi.org/10.1016/j.apenergy.2015.09.019.

287] A. Ghosh, B. Norton, A. Duffy, First outdoor characterisation of a PV powered suspended particle device switchable glazing, Sol. Energy Mater. Sol. Cells 157 (2016) 1-9, https://doi.org/10.1016/j.solmat.2016.05.013.

[288] A. Ghosh, B. Norton, A. Duffy, Daylighting performance and glare calculation of a suspended particle device switchable glazing, Sol. Energy 132 (2016) 114-128. https://doi.org/10.1016/j.solener.2016.02.051.

[289] A. Ghosh, B. Norton, A. Duffy, Effect of sky conditions on light transmission through a suspended particle device switchable glazing, Sol. Energy Mater. Sol. Cells 160 (2017) 134-140, https://doi.org/10.1016/j.solmat.2016.09.049.

[290] A. Ghosh, B. Norton, A. Duffy, Behaviour of a SPD switchable glazing in an outdoor test cell with heat removal under varying weather conditions, Appl $\begin{array}{lllll}\text { Energy } & 180 & \text { (2016) } & 695-706, & \text { https://doi.org/10.1016 }\end{array}$ j.apenergy.2016.08.029.

[291] A. Ghosh, B. Norton, Interior colour rendering of daylight transmitted through a suspended particle device switchable glazing, Sol. Energy Mater. Sol. Cells 163 (2017) 218-223, https://doi.org/10.1016/j.solmat.2017.01.041.

[292] D. Barrios, R. Vergaz, J.M. Sanchez-Pena, C.G. Granqvist, G.A. Niklasson, Toward a quantitative model for suspended particle devices: optical scattering and absorption coefficients, Sol. Energy Mater. Sol. Cells 111 (2013) 115-122, https://doi.org/10.1016/j.solmat.2012.12.012.

[293] R. Vergaz, J.M. Sánchez-Pena, D. Barrios, C. Vázquez, P. Contreras-Lallana, Modelling and electro-optical testing of suspended particle devices, Sol. Energy Mater. Sol. Cells 92 (2008) 1483-1487, https://doi.org/10.1016 j.solmat.2008.06.018.

[294] D. Barrios, R. Vergaz, J.M. Sánchez-Pena, B. García-Cámara, C.G. Granqvist G.A. Niklasson, Simulation of the thickness dependence of the optical properties of suspended particle devices, Sol. Energy Mater. Sol. Cells 143 (2015) 613-622, https://doi.org/10.1016/j.solmat.2015.05.044.

[295] G. Macrelli, Optical characterization of commercial large area liquid crystal devices, Sol. Energy Mater. Sol. Cells 39 (1995) 123-131, https://doi.org/ 10.1016/0927-0248(95)00044-5.

[296] K. Li, M. Pivnenko, D. Chu, A. Cockburn, W. O'Neill, Uniform and fast switching of window-size smectic A liquid crystal panels utilising the field gradient generated at the fringes of patterned electrodes, Liq. Cryst. 43 (2016) 735-749, https://doi.org/10.1080/02678292.2016.1142012.

[297] D.J. Gardiner, S.M. Morris, H.J. Coles, High-efficiency multistable switchable glazing using smectic A liquid crystals, Sol. Energy Mater. Sol. Cells 93 (2009) 301-306, https://doi.org/10.1016/j.solmat.2008.10.023.

[298] Y. Anjaneyulu, D.W. Yoon, A PCGH liquid crystal window to control solar energy, Sol. Energy Mater. 14 (1986) 223-232, https://doi.org/10.1016 0165-1633(86)90049-3.

[299] J. Torres, R. Vergaz, D. Barrios, J. Sánchez-Pena, A. Viñuales, H. Grande G. Cabañero, Frequency and temperature dependence of fabrication parameters in polymer dispersed liquid crystal devices, Materials 7 (2014) 3512-3521, https://doi.org/10.3390/ma7053512.

[300] G.P. Montgomery, J.L. West, W. Tamura-Lis, Light scattering from polymerdispersed liquid crystal films: droplet size effects, J. Appl. Phys. 69 (1991) 1605-1612, https://doi.org/10.1063/1.347256.

[301] A. Ghosh, B. Norton, T.K. Mallick, Solar Energy Materials and Solar Cells Daylight characteristics of a polymer dispersed liquid crystal switchable glazing, Sol. Energy Mater. Sol. Cells 174 (2018) 572-576, https://doi.org/ 10.1016/j.solmat.2017.09.047.

[302] A. Ghosh, T.K. Mallick, Evaluation of optical properties and protection factors of a PDLC switchable glazing for low energy building integration, Sol. Energy Mater. Sol. Cells (2017) 0-1, https://doi.org/10.1016/j.solmat.2017.10.026.

[303] A. Hadj Sahraoui, S. Delenclos, S. Longuemart, D. Dadarlat, Heat transport in polymer-dispersed liquid crystals under electric field, J. Appl. Phys. 110 (2011), https://doi.org/10.1063/1.3610445.

[304] S. Park, J.W. Hong, Polymer dispersed liquid crystal film for variabletransparency glazing, Thin Solid Films 517 (2009) 3183-3186, https:// doi.org/10.1016/j.tsf.2008.11.115.

[305] W. Zhang, J. Lin, T. Yu, S. Lin, D. Yang, Effect of electric field on phase separation of polymer dispersed liquid crystal, Eur. Polym. J. 39 (2003) 1635-1640, https://doi.org/10.1016/S0014-3057(03)00074-0.

[306] L. Petti, P. Mormile, W.J. Blau, Fast electro-optical switching and high contrast ratio in epoxy-based polymer dispersed liquid crystals, Optic Laser. Eng. 39 (2003) 369-377, https://doi.org/10.1016/S0143-8166(01)00119-1.

[307] D. Cupelli, G. De Filpo, G. Chidichimo, F.P. Nicoletta, The electro-optical and electrochromic properties of electrolyte-liquid crystal dispersions, J. Appl. Phys. 100 (2006), https://doi.org/10.1063/1.2219696.

[308] D. Cupelli, F.P. Nicoletta, S. Manfredi, G. De Filpo, G. Chidichimo, Electrically switchable chromogenic materials for external glazing, Sol. Energy Mater. Sol. Cells 93 (2009) 329-333, https://doi.org/10.1016/j.solmat.2008.11.010.

[309] D. Cupelli, F.P. Nicoletta, S. Manfredi, M. Vivacqua, P. Formoso, G. De Filpo G. Chidichimo, Self-adjusting smart windows based on polymer-dispersed liquid crystals, Sol. Energy Mater. Sol. Cells 93 (2009) 2008-2012, https:// doi.org/10.1016/j.solmat.2009.08.002.

[310] A. Ghosh, T.K. Mallick, Evaluation of optical properties and protection factors of a PDLC switchable glazing for low energy building integration, Sol. Energy Mater. Sol. Cells 176 (2017) 391-396, https://doi.org/10.1016/ j.solmat.2017.10.026 
[311] A. Ghosh, T.K. Mallick, Evaluation of colour properties due to switching behaviour of a PDLC glazing for adaptive building integration, Renew. Energy 120 (2018) 126-133, https://doi.org/10.1016/j.renene.2017.12.094.

[312] H. Hosseinzadeh Khaligh, K. Liew, Y. Han, N.M. Abukhdeir, I.A. Goldthorpe, Silver nanowire transparent electrodes for liquid crystal-based smart windows, Sol. Energy Mater. Sol. Cells 132 (2015) 337-341, https://doi.org/ 10.1016/j.solmat.2014.09.006.

[313] T. Tokuno, M. Nogi, M. Karakawa, J. Jiu, T.T. Nge, Y. Aso, K. Suganuma, Fabrication of silver nanowire transparent electrodes at room temperature Nano Res. 4 (2011) 1215-1222, https://doi.org/10.1007/s12274-011-0172-3.

[314] L. Hu, H.S. Kim, J. Lee, P. Peumans, Y. Cui, Scalable coating and properties of transparent Ag nanowire, ACS Nano 4 (2010) 2955-2963, https://doi.org $10.1021 / \mathrm{nn} 1005232$

[315] D. Jung, W. Choi, J.-Y. Park, K.B. Kim, N. Lee, Y. Seo, H.S. Kim, N.K. Kong Inorganic gel and liquid crystal based smart window using silica sol-gel process, Sol. Energy Mater. Sol. Cells 159 (2017) 488-495, https://doi.org 10.1016/j.solmat.2016.10.001.

[316] S. Papaefthimiou, G. Leftheriotis, P. Yianoulis, T.J. Hyde, P.C. Eames, Y. Fang, P.Y. Pennarun, P. Jannasch, Development of electrochromic evacuated advanced glazing, Energy Build. 38 (2006) 1455-1467, https://doi.org 10.1016/j.enbuild.2006.03.029.

[317] Y. Fang, P.C. Eames, Thermal performance of an electrochromic vacuum glazing, Energy Convers. Manag. 47 (2006) 3602-3610, https://doi.org/ 10.1016/j.enconman.2006.03.016.

[318] Y. Fang, P.C. Eames, The effect of glass coating emittance and frame rebate on heat transfer through vacuum and electrochromic vacuum glazed windows, Sol. Energy Mater. Sol. Cells 90 (2006) 2683-2695, https://doi.org/10.1016 j.solmat.2006.04.006.

[319] Y. Fang, P.C. Eames, B. Norton, T. Hyde, Y. Huang, N. Hewitt, The therma performance of an electrochromic vacuum glazing with selected lowemittance coatings, Thin Solid Films 516 (2008) 1074-1081, https:/ doi.org/10.1016/j.tsf.2007.07.210.

[320] Y. Fang, T. Hyde, N. Hewitt, P.C. Eames, B. Norton, Thermal performance analysis of an electrochromic vacuum glazing with low emittance coatings, Sol. Energy 84 (2010) 516-525, https://doi.org/10.1016/ j.solener.2009.02.007.

[321] A. Ghosh, B. Norton, A. Duffy, Effect of atmospheric transmittance on performance of adaptive SPD-vacuum switchable glazing, Sol. Energy Mater. Sol Cells 161 (2017) 424-431, https://doi.org/10.1016/j.solmat.2016.12.022.

[322] S.K. Deb, Supply 3 on electrophotography, Appl. Optic. 8 (1969) 192-195.

[323] M.C. Browne, B. Norton, S.J. McCormack, Phase change materials for photovoltaic thermal management, Renew. Sustain. Energy Rev. 47 (2015) 762-782, https://doi.org/10.1016/j.rser.2015.03.050.

[324] E. Radziemska, E. Klugmann, Thermally affected parameters of the currentvoltage characteristics of silicon photocell, Energy Convers. Manag. 43 (2002) 1889-1900, https://doi.org/10.1016/S0196-8904(01)00132-7.

[325] E. Radziemska, The effect of temperature on the power drop in crystalline silicon solar cells, Renew. Energy 28 (2003) 1-12, https://doi.org/10.1016 S0960-1481(02)00015-0.

[326] K.S. Ahn, S.J. Yoo, M.S. Kang, J.W. Lee, Y.E. Sung, Tandem dye-sensitized solar cell-powered electrochromic devices for the photovoltaic-powered smart window, J. Power Sources 168 (2007) 533-536, https://doi.org/10.1016/ j.jpowsour.2006.12.114.

[327] C. Bechinger, J.N. Bullock, J.-G. Zhang, C.E. Tracy, D.K. Benson, S.K. Deb, H.M. Branz, Low-voltage electrochromic device for photovoltaic-powered smart windows, J. Appl. Phys. 80 (1996) 1226-1232, https://doi.org/ $10.1063 / 1.363731$

[328] A. Hauch, A. Georg, S. Baumgärtner, U. Opara Krašovec, B. Orel, New photoelectrochromic device, Electrochim. Acta 46 (2001) 2131-2136, https:/I doi.org/10.1016/S0013-4686(01)00391-7.

[329] J.-J. Wu, M.-D. Hsieh, W.-P. Liao, W.-T. Wu, J.-S. Chen, Fast-switching photovoltachromic cells with tunable transmittance, ACS Nano 3 (2009) 2297-2303, https://doi.org/10.1021/nn900428s.

[330] B. ORegan, M. Gratzel, (c) 1991 nature publishing group, Nature 353 (1991) 737-739.

[331] U. Mehmood, A. Al-Ahmed, F.A. Al-Sulaiman, M.I. Malik, F. Shehzad, A.U.H. Khan, Effect of temperature on the photovoltaic performance and stability of solid-state dye-sensitized solar cells: a review, Renew. Sustain. Energy Rev. 79 (2017) 946-959, https://doi.org/10.1016/j.rser.2017.05.114.

[332] D.K. Benson, H.M. Branz, Design goals and challenges for a photovoltaic- powered electrochromic window covering, Sol. Energy Mater. Sol. Cells 39 (1995) 203-211, https://doi.org/10.1016/0927-0248(95)00041-0.

[333] J.N. Bullock, C. Bechinger, D.K. Benson, H.M. Branz, Semi-transparent a-SiC: H solar cells for self-powered photovoltaic-electrochromic devices, J. NonCryst. Solids 198-200 (1996) 1163-1167, https://doi.org/10.1016/00223093(96)00105-6.

[334] W. Gao, S. Lee, J. Bullock, Y. Xu, D. Benson, S. Morrison, H. Branz, First a-SiC: H photovoltaic-powered monolithic tandem electrochromic smart window device, Sol. Energy Mater. Sol. Cells 59 (1999) 243-254, https://doi.org/ 10.1016/S0927-0248(99)00025-2.

[335] W. Gao, P. Liu, R.S. Crandall, S.-H. Lee, D.K. Benson, H.M. Branz, Approaches for large-area a-SiC: $\mathrm{H}$ photovoltaic-powered electrochromic window coatings, J. Non. Cryst. Solids 266-269 (2000) 1140-1144, https://doi.org/ 10.1016/S0022-3093(99)00918-7.

[336] A. Cannavale, G.E. Eperon, P. Cossari, A. Abate, H.J. Snaith, G. Gigli, Perovskite photovoltachromic cells for building integration, Energy Environ. Sci. 8 (2015) 1578-1584, https://doi.org/10.1039/C5EE00896D.

[337] A.L. Dyer, R.H. Bulloch, Y. Zhou, B. Kippelen, J.R. Reynolds, F. Zhang, A vertically integrated solar-powered electrochromic window for energy efficient buildings, Adv. Mater 26 (2014) 4895-4900, https://doi.org/ 10.1002/adma.201401400.

[338] L.M. Huang, C.W. Hu, H.C. Liu, C.Y. Hsu, C.H. Chen, K.C. Ho, Photovoltaic electrochromic device for solar cell module and self-powered smart glass applications, Sol. Energy Mater. Sol. Cells 99 (2012) 154-159, https://doi.org/ 10.1016/j.solmat.2011.03.036

[339] L.M. Huang, C.P. Kung, C.W. Hu, C.Y. Peng, H.C. Liu, Tunable photovoltaic electrochromic device and module, Sol. Energy Mater. Sol. Cells 107 (2012) 390-395, https://doi.org/10.1016/j.solmat.2012.07.021.

[340] R.H. Ma, Y.C. Chen, BIPV-powered smart windows utilizing photovoltaic and electrochromic devices, Sensors 12 (2012) 359-372, https://doi.org/ $10.3390 / \mathrm{s} 120100359$

[341] A. Ghosh, B. Norton, A. Duffy, A. Ghosh, B. Norton, A. Duffy, Conceptualization of a Photovoltaic Powered Electrochromic Switching of a Multifunctional Glazing Conceptualization of a Photovoltaic Powered Electrochromic Switching of a Multifunctional Glazing, 2014.

[342] G. Teowee, T. Gudgel, K. McCarthy, A. Agrawal, P. Allemand, J. Cronin, User controllable photochromic (UCPC) devices, Electrochim. Acta 44 (1999) 3017-3026, https://doi.org/10.1016/S0013-4686(99)00015-8.

[343] C. Costa, I. Mesquita, L. Andrade, A. Mendes, Photoelectrochromic devices: influence of device architecture and electrolyte composition, Electrochim. Acta 219 (2016) 99-106, https://doi.org/10.1016/j.electacta.2016.09.142.

[344] G. Leftheriotis, G. Syrrokostas, P. Yianoulis, Photocoloration efficiency and stability of photoelectrochromic devices, Solid State Ionics 231 (2013) 30-36, https://doi.org/10.1016/j.ssi.2012.10.024.

[345] S. Bogati, A. Georg, W. Graf, Photoelectrochromic devices based on sputtered WO3 and TiO2 films, Sol. Energy Mater. Sol. Cells 163 (2017) 170-177, https://doi.org/10.1016/j.solmat.2017.01.016.

[346] A. Ghosh, B. Norton, A. Duffy, First outdoorcharacterisation of a PV powered suspended particle device switchable glazing, Sol. Energy Mater. SolarCells 157 (2016) 1-9.

[347] H.K. Kwon, K.T. Lee, K. Hur, S.H. Moon, M.M. Quasim, T.D. Wilkinson, J.Y. Han, H. Ko, I.K. Han, B. Park, B.K. Min, B.K. Ju, S.M. Morris, R.H. Friend, D.H. Ko, Optically switchable smart windows with integrated photovoltaic devices, Adv. Energy Mater. 5 (2015) 1-6, https://doi.org/10.1002/aenm.201401347.

[348] A. Ghosh, Multifunctional Glazing System- Solution for Modern Smart Glazing, 2014, pp. 1-8.

[349] W. Zhang, L. Lu, X. Chen, Performance evaluation of vacuum photovoltaic insulated glass unit, Energy Procedia 105 (2017) 322-326, https://doi.org/ 10.1016/j.egypro.2017.03.321.

[350] T.R. Whiffen, S. Naylor, J. Hill, L. Smith, P.A. Callan, M. Gillott, C.J. Wood, S.B. Riffat, A concept review of power line communication in building energy management systems for the small to medium sized non-domestic built environment, Renew. Sustain, Energy Rev. 64 (2016) 618-633, https:// doi.org/10.1016/j.rser.2016.06.069.

[351] H.R. Shaker, S. Lazarova-Molnar, A new data-driven controllability measure with application in intelligent buildings, Energy Build. 138 (2017) 526-529, https://doi.org/10.1016/j.enbuild.2016.11.027.

[352] T.A. Nguyen, M. Aiello, Energy intelligent buildings based on user activity: a survey, Energy Build. 56 (2013) 244-257, https://doi.org/10.1016/ j.enbuild.2012.09.005. 